The contrast between Jew and Zhou People(周人)

Bohai Xu

Address: Suzhou Industrial Park, Suzhou, China

Abstract: The Spring Festival is one of the most important and traditional Chinese festivals. It has a long history and rich and colorful folk-custom characteristics, such as the family reunion, eating dumplings, setting off firecrackers, pasting the spring couplets, etc. Those characteristics are the reflections of traditional Chinese thinking ways and the thoughts of Confucianism. For Passover, it is like the twin-brother of the Spring Festival. During Passover, the Jewish people gather and commemorate the grace of God and the hardship of the ancestors. Passover opens a door for the further study on the thoughts and culture of the ancient Israelites, and their view on God. Their folk customs including family reunion, brushing the lamb blood on the door frame, eating unleavened bread and bitter herbs, and some other folk events that are similar to those of the Spring Festival. From the paper, we can get a hypothesis that the beast $\mathrm{Xi}$ (夕) is Set with Chinese characteristic. By the way, from the paper, we can get a hypothesis that God in Judaism and Shangdi(上 帝) and Tian(天) are nearly the same. Besides, we can also get a hypothesis that the Christian notion of a divine right of kings resembles the Mandate of Heaven(天命). By the way, from the paper, we can get a conclusion that Qi(弃) is actually Hemaka. Besides, from the paper, we can say that the origin of the doctrine of the mean may be the scales of justice emblem of the tribe of Dan. Furthermore, most of Q-M242 people in East Asia belong to subclade Q-M120, which distributes most intensively across northern China. The average frequency of Q-M242 in 
northern China is around $4.5 \%$. However, it decreases to about $2 \%$ in southern China. According to the dynastic race theory, the Haplogroup of the elite of the ancient Egypt(especially pharaohs) may be Q. By the way, the highest frequency of Q1b1 in Europe is found among Ashkenazi Jews $(5 \%)$ and Sephardic Jews (2\%), suggesting that Q1b was present in the Levant before the Jewish disapora 2,000 years ago. In fact, Jewish Q1b all belong to the Y2200 subclade, which was formed some 2,600 years ago. So in all, we can get a hypothesis that Zhou People(周人) may be the Tribe of Dan , one of the tribes of Israel. 
It was written in Er'ya,(尔雅) “For the year, it was called Sui(岁)in Xia Dynasty (2070B.C.-1600B.C.); it was called Si (祀 )in Shang Dynasty (1600B.C.-1046B.C.); it was called Nian (年)in Zhou Dynasty(1046B.C.249A.D.)." Although there are many different views about the origin of the Spring Festival. A generally accepted notion is that the Spring Festival is related to the ancient agricultural sacrifice rite, “Laji”(腊祭), in the primitive society of China. When the winter has gone and the spring is coming, the ancient Chinese people would kill the livestock like pigs, lambs, and oxen to serve theirs Gods and ancestors as offerings. They would leave their wishes on those offerings and pray for good weather for the crops in the new year and that disasters and diseases would not come down upon them. People would brush their face with cinnabar and decorate themselves with feathers. Then they would dance and sing to worship the Gods. The bustling "Laji" gradually became the Spring Festival in Xia Dynasty. The Spring Festival is also called the Lunar New Year, and “Guonian”(过年) in Chinese. “Guonian” in verb means having the Spring Festival. “Nian”(年) was defined as the harvest of the grains and fruits in the inscriptions on bones or tortoise shells of the Shang Dynasty and on ancient bronze objects. During Han Dynasty(202B.C.220A.D.), people set the Beginning of Spring, one of the 24 Chinese solar terms, as the Spring Festival. During the Northern and Southern Dynasties, the whole spring was the Spring Festival. Nowadays, in PRC, the Spring Festival holiday is from the first day to the seventh day of the lunar year for people to celebrate and enjoy themselves. However, traditionally speaking, the Spring Festival is longer than a week. It is from the $23^{\text {rd }}$ of the twelfth month of the lunar year to the $15^{\text {th }}$ of the first month of the Lunar New Year. During a lunar year, the three most 
important days of the Spring Festival are the last day “Chuxi”(除夕), the first day, and the $15^{\text {th }}$ day “Yuanxiao"(元宵).

Passover is a word from Bible. When we mention the origin of Passover, the three important key words are Exodus, Moses, and ten plagues. So, why did the Israelites exodus? After the Israelites immigration came and multiplied in the land of Egypt with Joseph's family for many years, a new king succeeded and regarded the fruitful Israelites as a threat. Therefore, he took the cruel action:

And they made the Israelites serve rigorously. Every kind of service the Israelites were required to give was rigorous. The king of Egypt said to the Hebrew midwives, "when you assist the Hebrew women in childbirth, observe at the delivery: if it is a son, kill him, but if it is a daughter, she may live." (Exodus 1:13-16 NET)

The Israelites were in an abyss of suffering and slavery. They prayed hard to God and called for help and delivery. However, there was a lucky Levi boy who escaped from his fatal birth and was adopted by the Pharaoh's daughter and became one of the royal members. (c. 1526 B.C.)

He was the selected one by God who would lead the Israelites to freedom. With the awakening of his Israeli identity, he killed an Egyptian who was attacking a Hebrew and ran away from his prince life as a wanted man. Forty years in desert passed away, and Moses accepted the mission given by God to save the Israel. However, the ruler of Egypt would not likely allow the Israeli slaves to exodus. The resulting outcome was that God sent plagues to Egypt, some through Moses. But the Pharaoh still disagreed to let them go. The trump card for God was to kill all the first-born sons on the land of Egypt, except the Israelites first- 
born sons. God passovered the Israelites, and finally with the leading of Moses, they got out of the ruling of the Pharaoh and won the independence of their nation. To commemorate this phase of history and how God saved His people, this event, Passover, or the Feast of Unleavened Bread, became one of the most important festivals for the Israelites. "So you will keep the Feast of Unleavened Bread, because on this very day I brought your regiments out from the land of Egypt, and so you perpetually as lasting ordinance" (Exodus 12:17 NET).

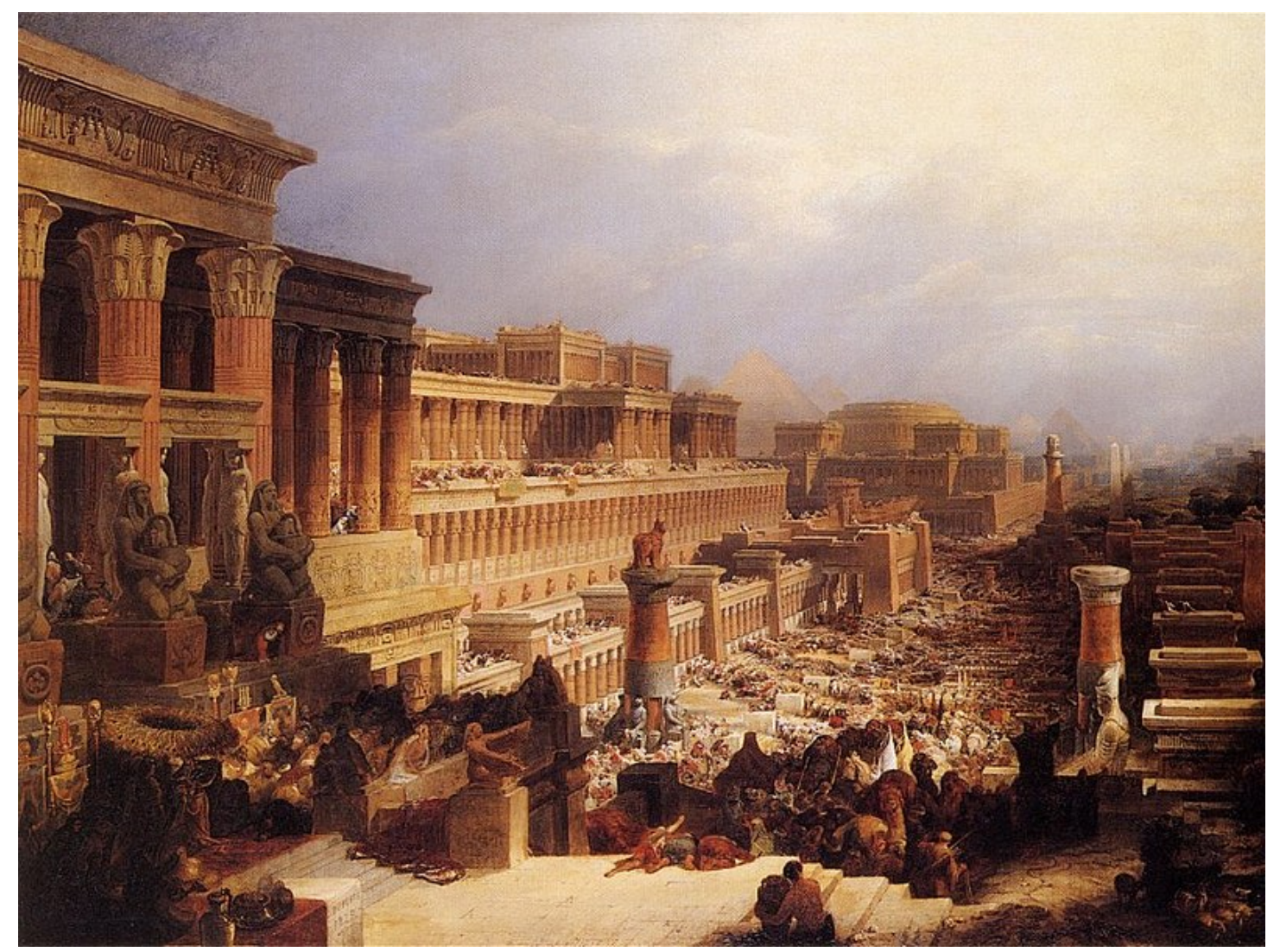

Departure of the Israelites (David Roberts, 1829) 


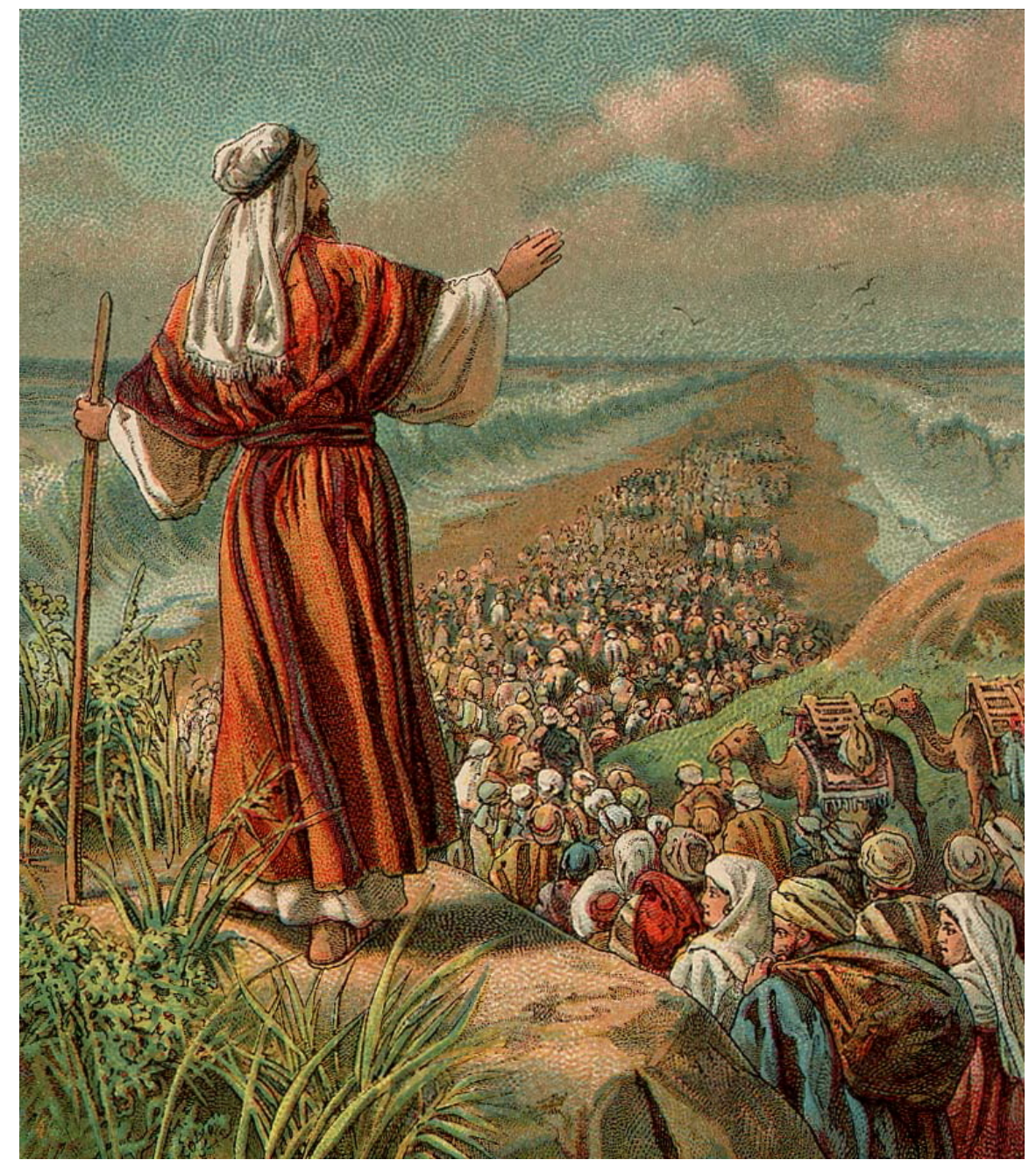

Illustration of The Exodus from Egypt, 1907

Both the Spring Festival and Passover have a long history. According to the remote record, the beginning of the spring festival is about 4000 years ago, the pre-Qin period. And the time Moses took the Israelites to exodus and opened the Red Sea is in 1446 B.C..

It is also about 4000 years ago. Traditionally, the beginning of the Passover is on the night of the $14^{\text {th }}$ of the first month of Jewish calendar, the month of Nisan. It will last for 7 days until the night of $21^{\text {st }}$. During the 7 days, the first and the last are the most ceremonious over Passover. For Chinese, the Spring Festival lasts even longer. It formally begins on the night of the last day of the past year in Chinese lunar calendar until 
the night of the $15^{\text {th }}$ day. This last day is also a festival for Chinese, the Lantern Festival. Also, the first day "Chuxi"(除夕) and the last day "Yuanxiao" ( 元宵) are obviously the most important over the Spring Festival. Nowadays for most Chinese people, the 16 days long festival is cut into one week for holiday in the busy modern society.

There are many amazing similarities between the mores of the Spring Festival and Passover from the beginning to the end of the both. From the perspective of custom, we can say they are nearly the same. The following raises the examples for the mores. During the two festivals, Chinese people clean the house, and the Israelites people put away the yeast; Chinese people paste the spring couplets on the doorframe, and the Israelites people brush the lamb's blood, in addition the similar eating and drinking customs, family reunion and ancestor reunion, staying up on the festival's eve, holy convocations and temple fairs, and gift money.

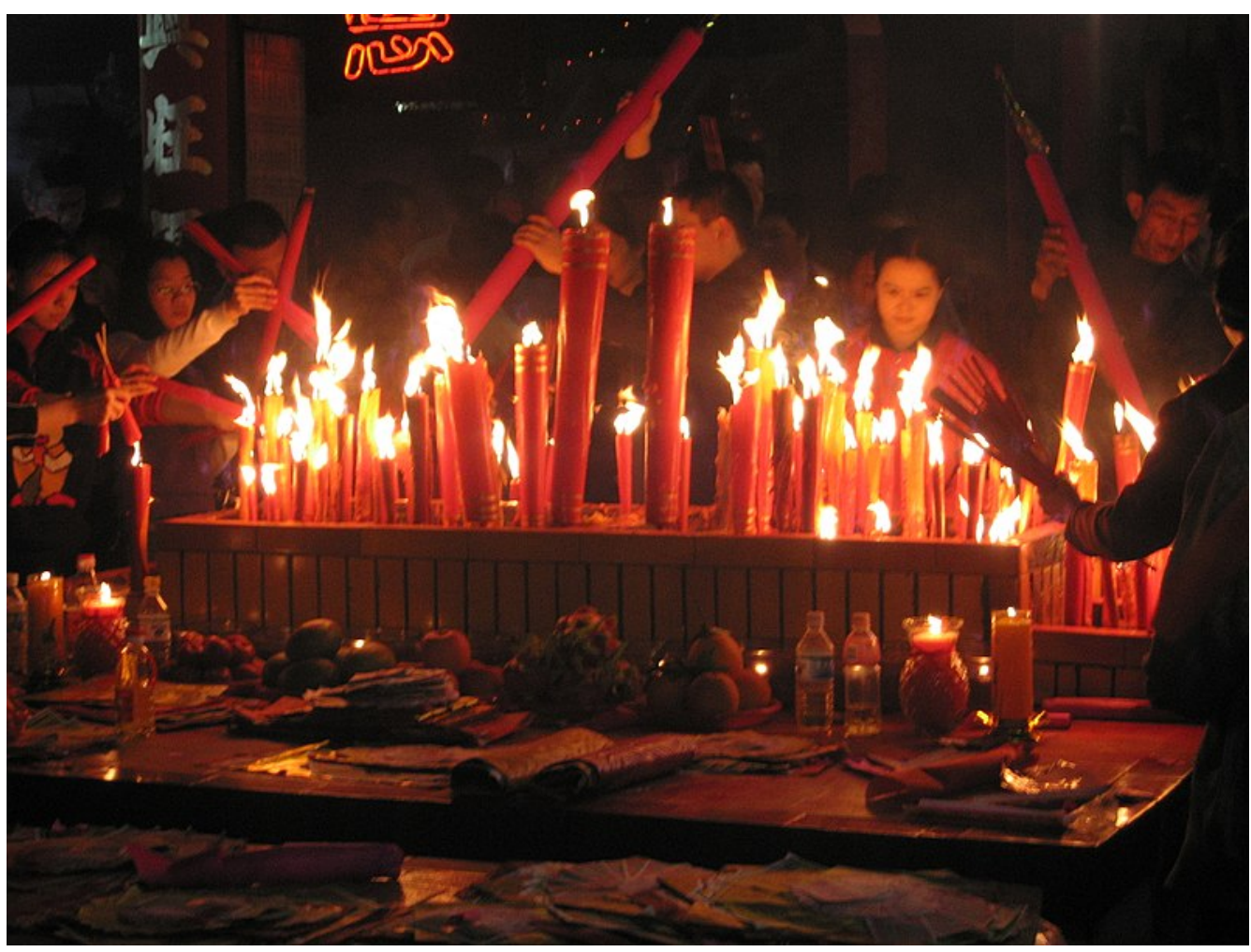




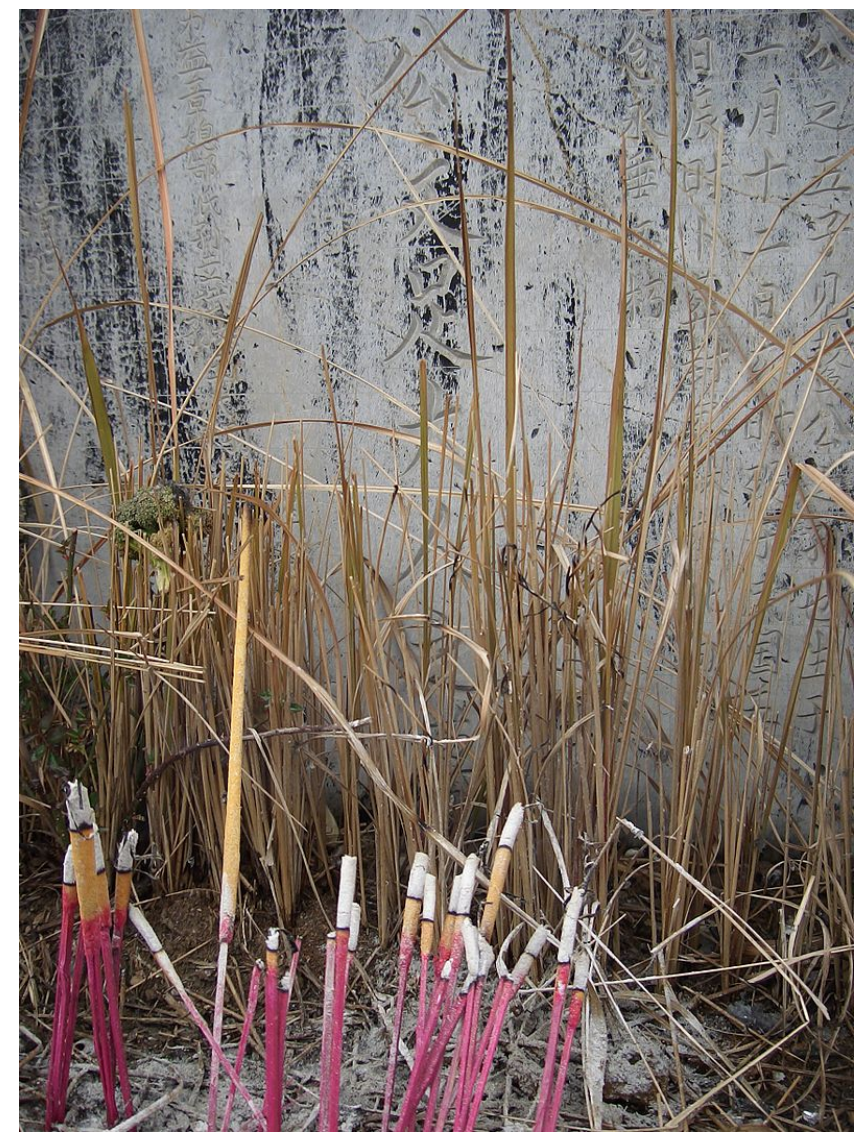

Incense is burned at the graves of ancestors as part of the offering and prayer rituals.

Passover is also called the Feast of Unleavened Bread. Before it comes, all the Jewish families will collect all the things that may contain yeast. They clean the house carefully in case of any possible yeast. Including the refrigerator, the oven, the microwave oven and the cupboard, they will clean them very carefully in case of any left food to leaven. Further more they bring out the new tablewares and ingredients without yeast. Finally, They remove the leavened food and yeast out of their house and burn it with prayer, "These not found leavened things are regarded nonexistent, and will become dust and mud.". 
Surely on the first day you must put away yeast from your house...For seven days yeast must not be found in your houses. Bread without yeast must be eaten for seven days; no bread made with yeast shall be seen among you, and you must have no yeast among you within any of your borders. (Exodus 12:15 12:19 13:7 NET)

Like the Israelites, the first thing that the Chinese people prepare for the coming spring festival is also by cleaning the house. A Chinese saying goes, "On the $24^{\text {th }}$ day of the twelfth month of the lunar year, sweep the floor and clean the house." Therefore, that is why the first day of Spring Festival is called "Chuxi"(除夕) which means sweeping the dust in the past at evening. The Folk Songs' Miscellany in Tang Dynasty names it "Suichu"(岁除) which means sweeping away the past year. The spring cleaning originates many years ago. And "Chuxi" also refers to "Songzao" (送灶)and "Zao"(灶) is a kind of kitchen ware in China. "Songzao" in other words is to clean the kitchen totally. Sometimes in the traditional Chinese family, they will light a pair of red candles to worship "Zaowangye"(灶王爷), the Kitchen God who is the controller of human's food and drink. But why do they pay so much attention on the cleaning of kitchen? One possible reason for me is that is a common place where the yeast can be found.

During Passover, the Israelites will kill the lamb and brush its blood on the door frame, which is exactly on the place that the Chinese people paste their spring couplets on. In addition, the color of the spring couplets and lamb blood is the same, red. "You must care for it until the fourteenth day of this month, and then the whole community of Israel will kill it around sundown. They will take some of the blood and put it 
on the two side posts and top of the doorframe of the houses where they eat it" (Exodus 12:6-7 NET).

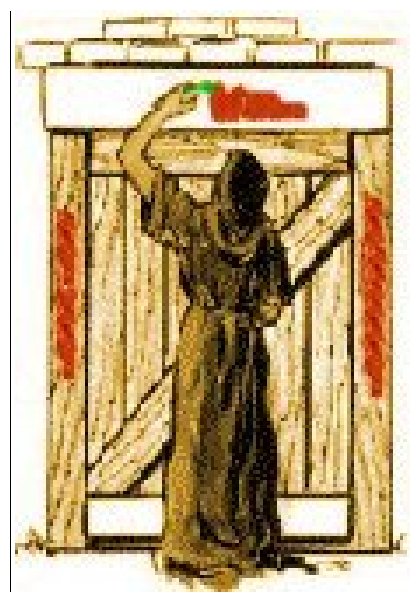

The Blood of the Lamb during Passover

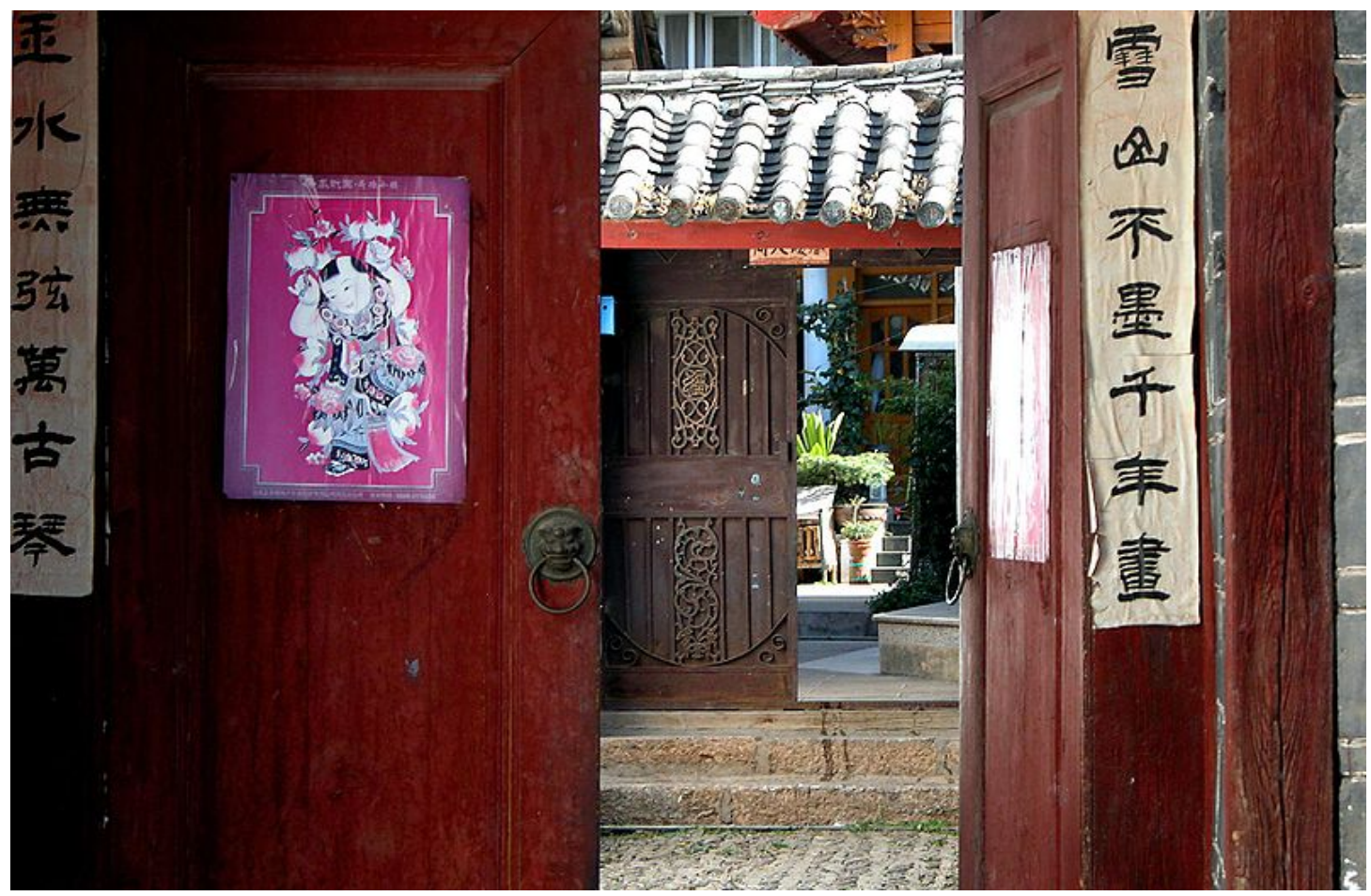

Hand-written Chinese New Year's poetry pasted on the sides of doors leading to people's homes, Lijiang, Yunnan 


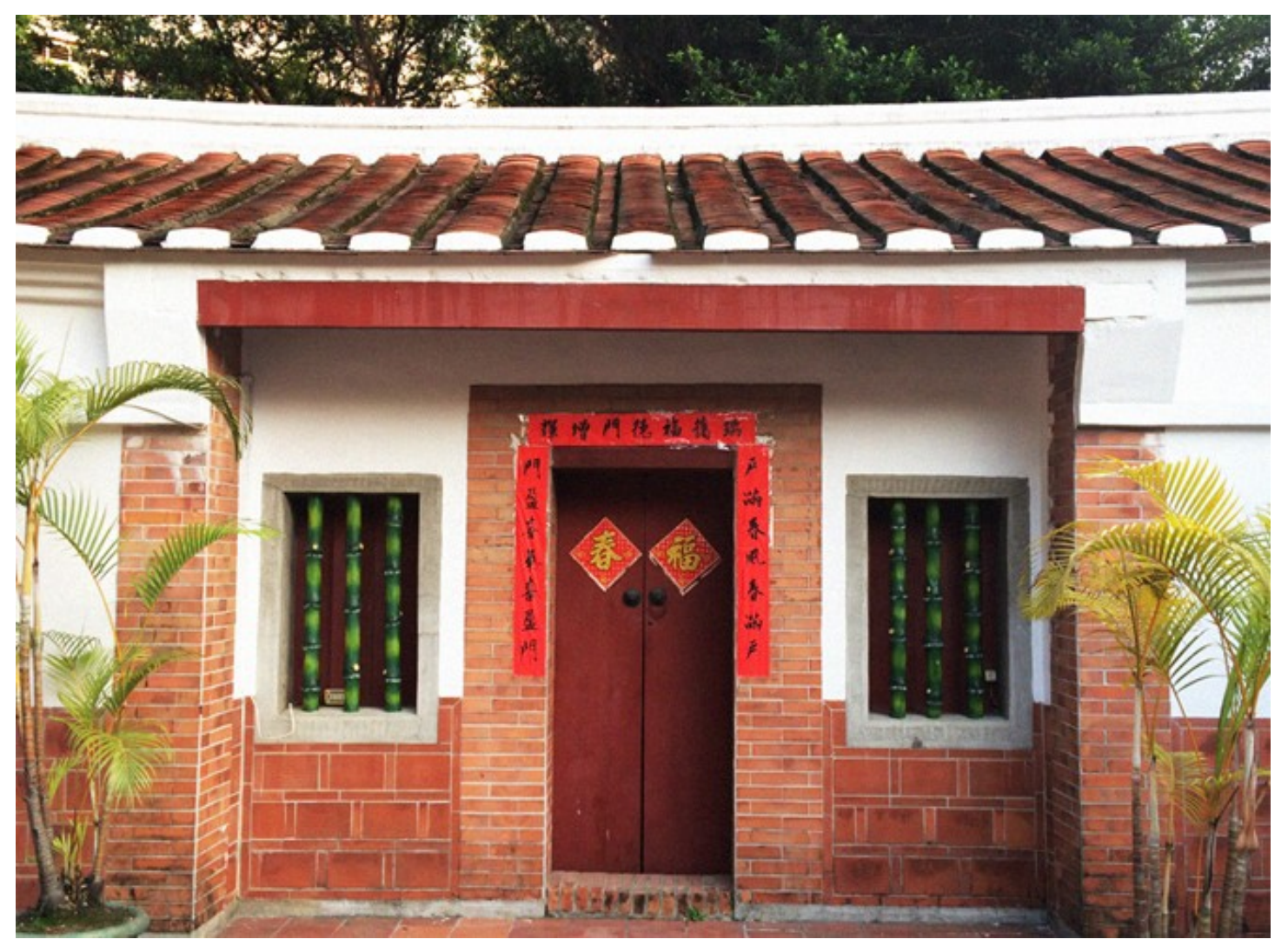

The lunar new year couplet paste on Tsoo-Tshu.( Taiwanese traditional house) ,New Taipei City, Taiwan

During the Spring Festival, the Chinese people will paste the red spring couplets and red paper-cuts as window decoration, and hang the red lanterns. Why do the Chinese people love the color red so much? One possible reason is that the color red may have the function to drive out evil spirits in the subconscious thinking of Chinese mind. The origin of the red spring couplet is the peach wood charms. Wang Anshi, an ancient Chinese poet wrote, "With the firecrackers booming, the new year come. Drink the Tusu in the warm spring breeze. Every family gets reunion in the special day. And it is the time to replace the old peach wood charms with new ones. "The peach wood charms are made by the red peach wood. Dating from the late Warring States Period, the ancient people regarded the red peach wood as a tool to expel the evil spirit. 
Then the red peach wood gradually turned into the red couplet, the red paper and black handwriting, in the past 2000 years.

Except for the red peach wood, would the ancient Chinese kill animals and brush their blood on the door frame? In the Eastern Han Dynasty Ying Shao's The Discussion of Customs-Taishigong Scroll, records that people learned from Duke De of Qin (秦德公)to kill the white dog and take its blood to brush the door frame in order to scare the evil spirits during the spring festival of Eastern Han Dynasty. Also, people in Wei Dynasty killed the chicken and used its blood to brush the door Imperial Reading of the Taiping, it was written clearly in the book that only this way conformed to the rites of the Spring Festival.

The Israelites killed the lamb as the sacrifice to God and they brushed the lamb's blood to identify themselves to get the chance to passover from death and protected their first born sons, and the ancient Chinese killed the dog, the chicken, or the cow and took the blood to brush doorframe to drive the evil spirits and to protect themselves. Ignoring the animal species, brushing the blood on the doorframe, or pasting the red spring couplets or peach wood charms, the color is red, and the purpose is to avoid killing or evil spirits and to protect the life safety.

For both the Israelites and Chinese, Passover and the Spring Festival are the times for families to reunite together. During the Spring festival, all the family members gather to enjoy the time with each other. Even in the Western Han Dynasty(206B.C.-24A.D.), the prisoners would even be liberated and allowed to spend the Spring Festival with their family. Likewise, the Israelites will go home all around, and gather with their 
family right before the coming of Passover, which is just like the Spring Festival traveling for billions of Chinese.

What do the Israelites eat during Passover? The Bible mentions about it clearly. "They will eat the meat the same night; they will eat it roasted over the fire with bread made without yeast and bitter herbs. Do not eat it raw or boiled in water, but roast it over the fire with its head, its legs, and its entrails" (Exodus 12:8-9 NET). Briefly, they eat the unleavened bread as staple food, the roasted lamb meat, and the bitter herbs.

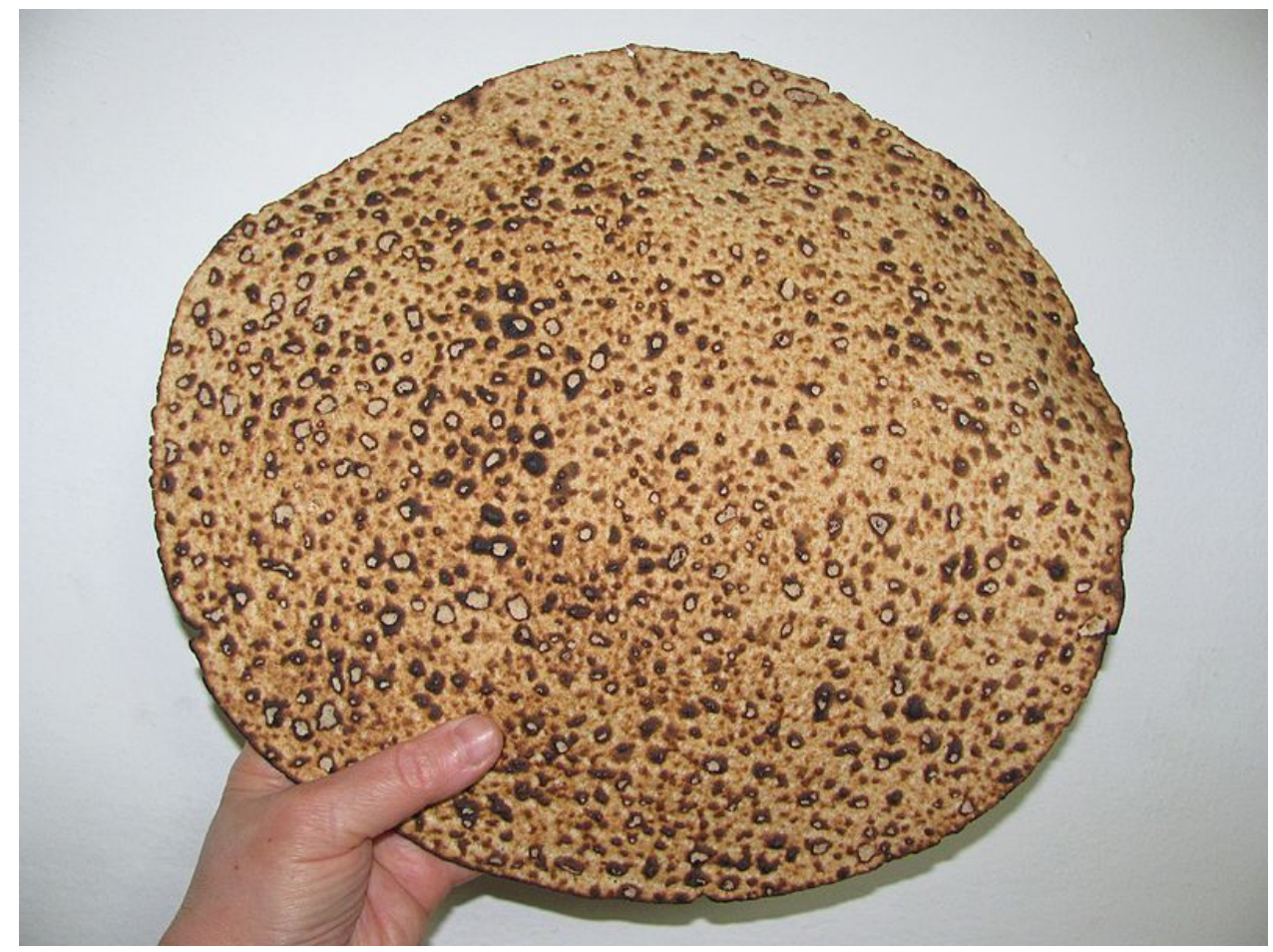

Hand made shmura matzo

Why do they eat bread without yeast? The Hebrew culture experts think yeast is unholy and evil food. The unleavened bread is a kind of baked round bread without any condiment. When they eat it, they usually split it into pieces and dip in sauce which is the mixture of nuts, jam and vinegar. For most of the northern Chinese people, their staple food is dumplings. Although there are no requirements for no yeast, 
dumplings, rice cakes, spring rolls, they are all common and unleavened food. Also when eat dumplings, Chinese people dip them in sauce like vinegar.

The Israelites also regard family as the unit for the Passover gathering like the gathering for Chinese in the Spring Festival.

The roasted lamb provides meat for the Israelites to eat, and is a sacrifice too. Far from the remote time, the ancient Chinese people also killed sheep or goat as the sacrifice. The Book of Rites-Yueling, (礼记. 月 令)“In spring, eat sheep or goat and wheat. Kill the lamb to thaw the ice, then offer it to the temple."

The wine for the Israelites in the Seder is like the drink for Chinese people in "Chuxi". Why do the Israelites like drinking wine? "As well as wine that makes people feel so good" (Exodus 104: 15 NET). Chinese people also drink during the family feast of "Chuxi", the last day of one year. Unlike making toasts to thank God all together for Israelites, they like making toasts to the individual or group. Toasting makes the Israelites recall the past, while a toast give Chinese the chance to express their expectation for the future. Therefore, they will fill the cup as the things they expect will happen perfectly.

According to tales and legends, the beginning of the Chinese New Year started with a mythical beast called the Xi (a beast that lives under the sea or in the mountains) during the annual Spring Festival. The Xi (夕)would eat villagers, especially children in the middle of the night. One year, all the villagers decided to go hide from the beast. An old man, appeared before the villagers went into hiding and said that he would 
stay the night, and would get revenge on the $\mathrm{Xi}$ (夕). All the villagers thought he was insane. The old man put red papers up and set off firecrackers. The day after, the villagers came back to their town and saw that nothing had been destroyed. They assumed that the old man was a deity who came to save them. The villagers then understood that Yanhuang had discovered that the Xi was afraid of the color red and loud noises(Chan Sui Jeung (2001). Traditional Chinese Festivals and Local Celebrations. Wan Li Book Company Limited.). So the tradition grew that when New Year was approaching, the villagers would wear red clothes, hang red lanterns, and red spring scrolls on windows and doors. People also used firecrackers to frighten away the Xi. From then on, Xi never came to the village again. The $\mathrm{Xi}$ was eventually captured by Hongjun Laozu, an ancient Taoist monk. After that, Xi retreated to a nearby mountain. The name of the mountain has long been lost over the years("The Origin of Lunar New Year and the legend of Nian". Ancient Origins. 31 January 2014. Retrieved 6 September 2015.). 


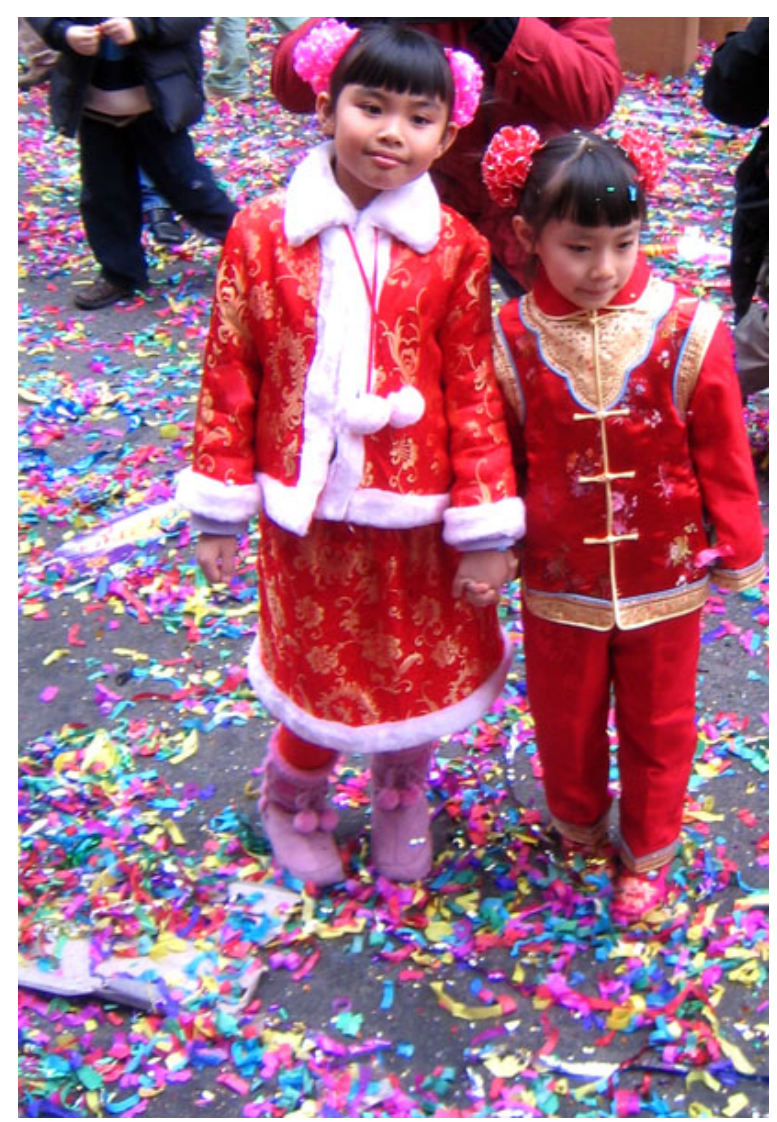

Girls dressed in red (Hong Kong) during Chinese New Year

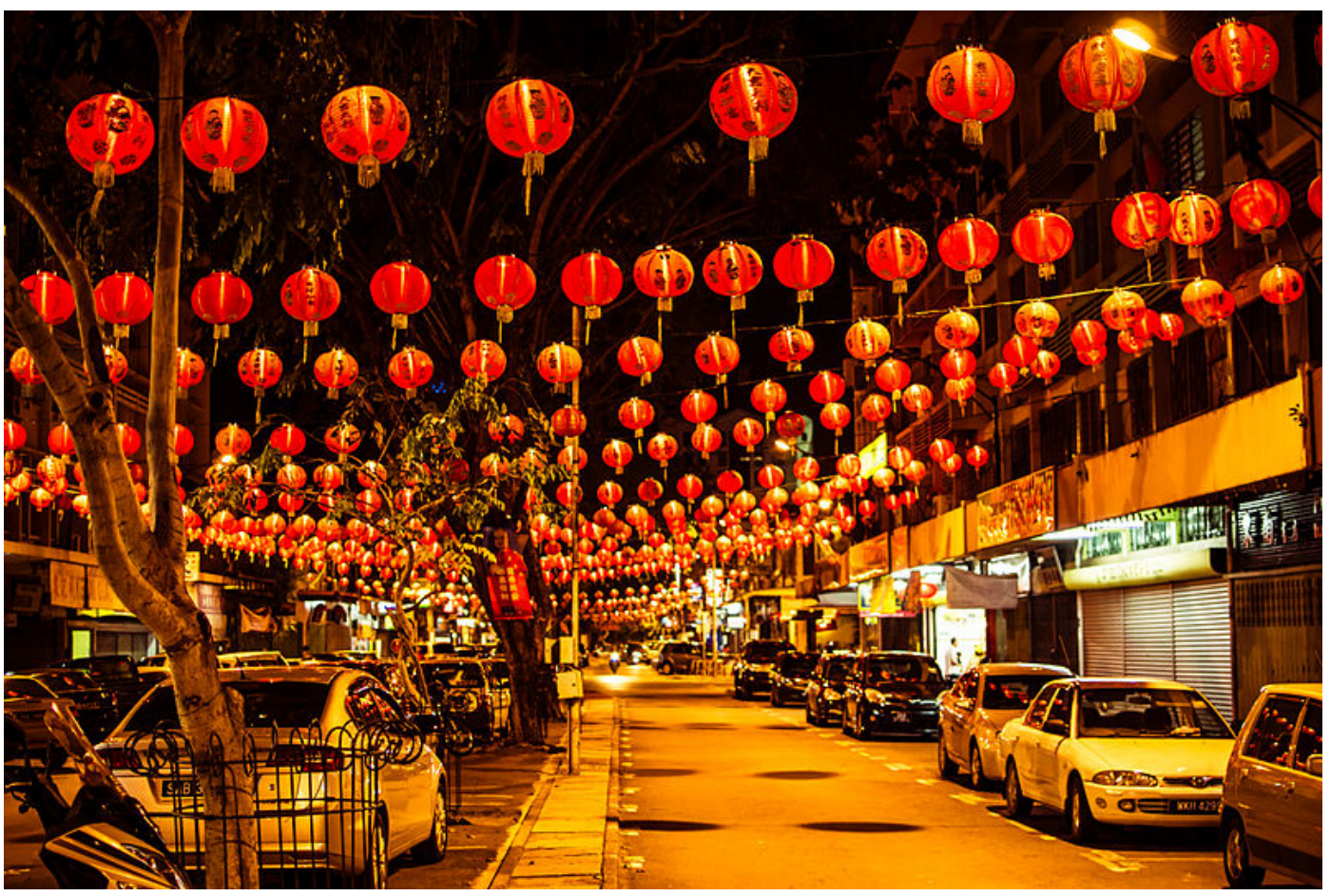

Gaya Street in Kota Kinabalu, Malaysia filled with Chinese lanterns during the New Year celebration. 


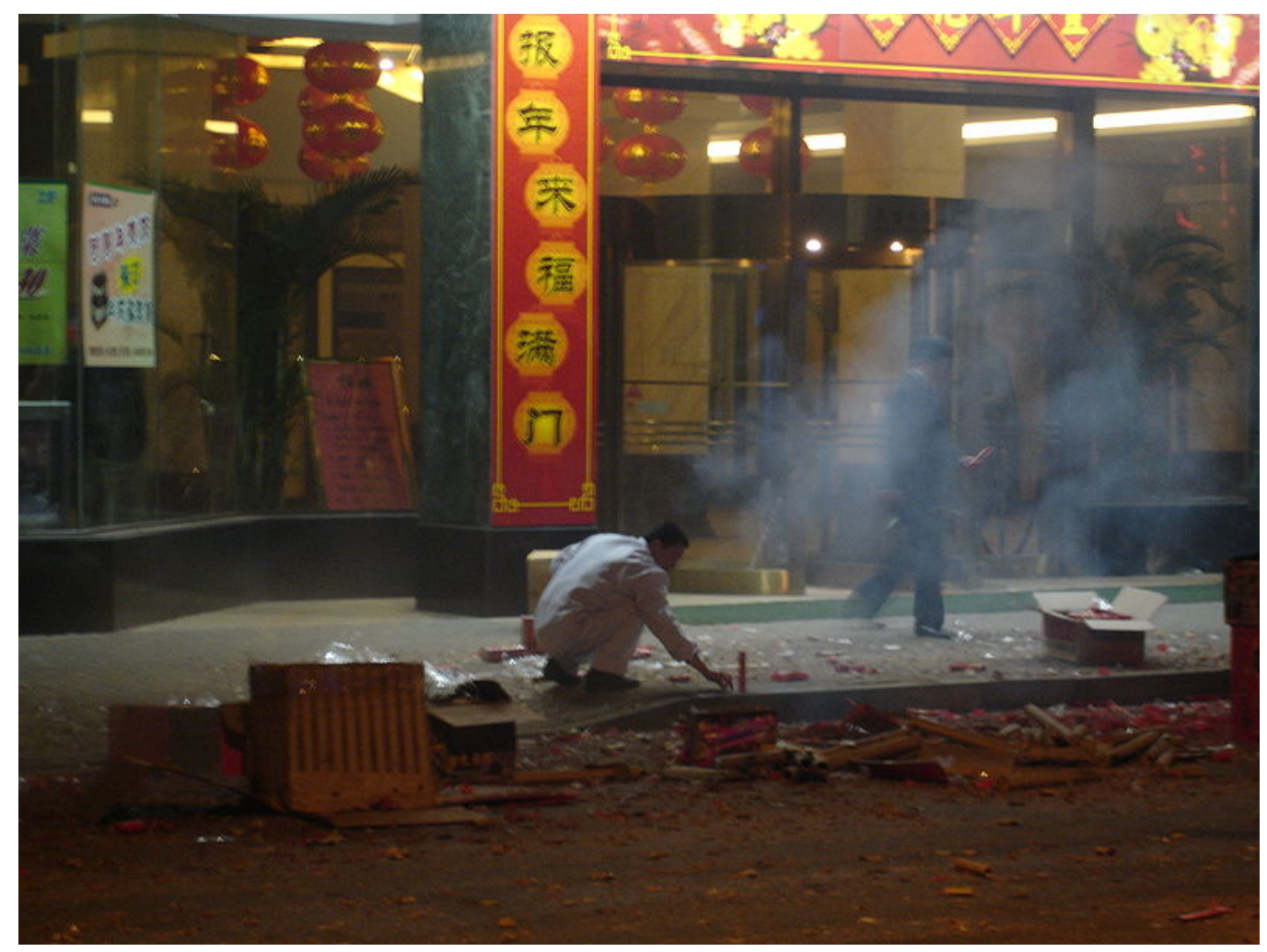

A Chinese man setting off fireworks during Chinese New Year in Shanghai.

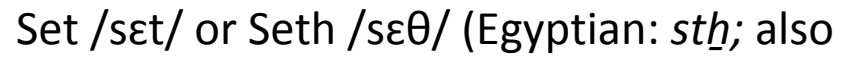
transliterated as Sheth, Setesh, Sutekh, Setan, Seth Merksamer, Seteh(Oxford Encyclopedia of Ancient Egypt, vol. 3, p. 269) Setekh, or Suty) is a god of chaos, fire, deserts, trickery, storms, envy, disorder, violence, and foreigners in ancient Egyptian religion( Oxford Encyclopedia of Ancient Egypt, vol. 3, p. 269). In Ancient Greek, the god's name is given as $\operatorname{Se} t h(\Sigma \eta \dot{\theta} \theta$. Set had a positive role where he accompanies Ra on his solar boat to repel Apep, the serpent of Chaos. Set had a vital role as a reconciled combatant. He was lord of the red (desert) land, where he was the balance to Horus' role as lord of the black (soil) land( Oxford Encyclopedia of Ancient Egypt, vol. 3, p. 269). 


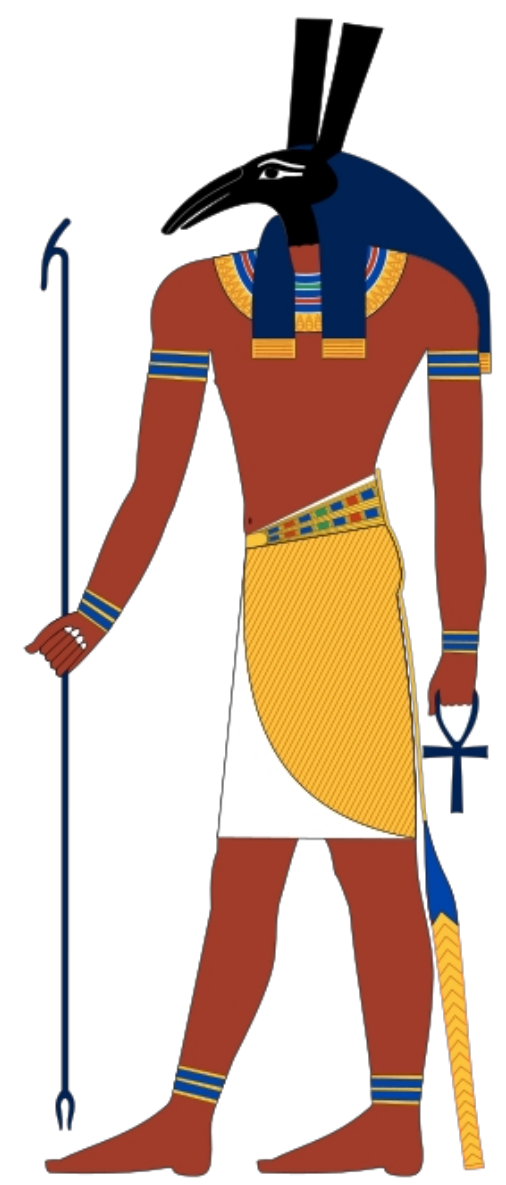

Set, an ancient Egyptian deity. Based on New Kingdom tomb paintings.

The meaning of the name Set is unknown but it is thought to have been originally pronounced *sūtih ['suw.tix'] based on spellings of his name in Egyptian hieroglyphs as sth and swth (te Velde 1967, pp.1-7.) The Late Egyptian spelling stš reflects the palatalization of $\underline{h}$ while the eventual loss of the final consonant is recorded in spellings like swtj("Thesaurus Linguae Aegyptiae". aaew2.bbaw.de. Retrieved 2017-09-21.) (Its pronunciation is similar to Chinese character 夕 $(\mathrm{Xi})$ ) 


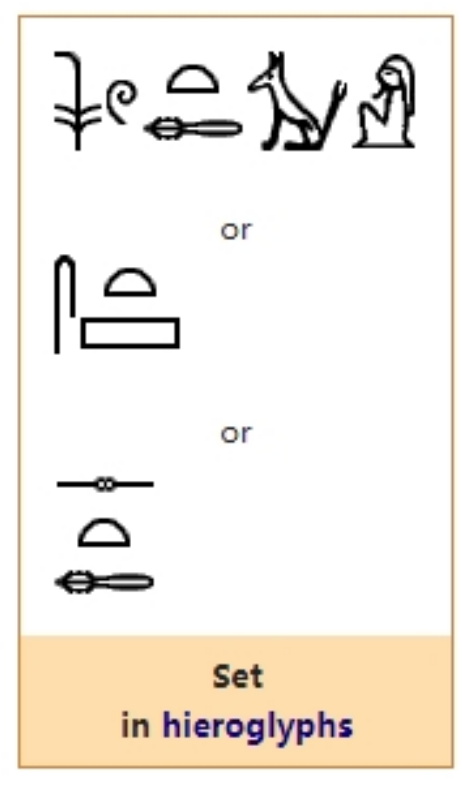

In art, Set is usually depicted as an enigmatic creature referred to by Egyptologists as the Set animal, a beast resembling no known creature, although it could be seen as a composite of an aardvark, a donkey, a jackal, or a fennec fox. The animal has a curved snout, long rectangular ears, a thin forked tail and canine body, with sprouted fur tufts in an inverted arrow shape; sometimes, Set is depicted as a human with the distinctive head. Some early Egyptologists proposed that it was a stylised representation of the giraffe, owing to the large flat-topped "horns" which correspond to a giraffe's ossicones. The Egyptians themselves, however, made a distinction between the giraffe and the Set animal. During the Late Period, Set is depicted as a donkey or as having a donkey's head(te Velde 1967, pp. 13-15).

The earliest representations of what might be the Set animal comes from a tomb dating to the Amratian culture("Naqada I") of prehistoric Egypt (3790 BC-3500 BC), though this identification is uncertain. If these are ruled out, then the earliest Set animal appears on a ceremonial 
macehead of Scorpion II, a ruler of the Naqada III phase. The head and the forked tail of the Set animal are clearly present(te Velde 1967, pp. 7-12).

A major element of Set's mythology was his conflict with his brother or nephew, Horus, for the throne of Egypt. In a key episode in the conflict, Set sexually abuses Horus. Set's violation is partly meant to degrade his rival, but it also involves homosexual desire, in keeping with one of Set's major characteristics, his forceful, potent, and indiscriminate sexuality (te Velde 1967, pp.55-56, 65). In the earliest account of this episode, in a fragmentary Middle Kingdom papyrus, the sexual encounter begins when Set asks to have sex with Horus, who agrees on the condition that Set will give Horus some of his strength(Griffiths 1960, p. 42).The encounter puts Horus in danger, because in Egyptian tradition semen is a potent and dangerous substance, akin to poison(It is similar to ancient Chinese medicine thought that "one drop of essence, ten drops of blood") According to some texts, Set's semen enters Horus's body and makes him ill, but in "Contendings", Horus thwarts Set by catching Set's semen in his hands. Isis retaliates by putting Horus's semen on lettuce-leaves that Set eats. Set's defeat becomes apparent when this semen appears on his forehead as a golden disk. He has been impregnated with his rival's seed and as a result "gives birth" to the disk. In "Contendings", Thoth takes the disk and places it on his own head; in earlier accounts, it is Thoth who is produced by this anomalous birth (te Velde 1967, pp. 38-39, 43-44). 


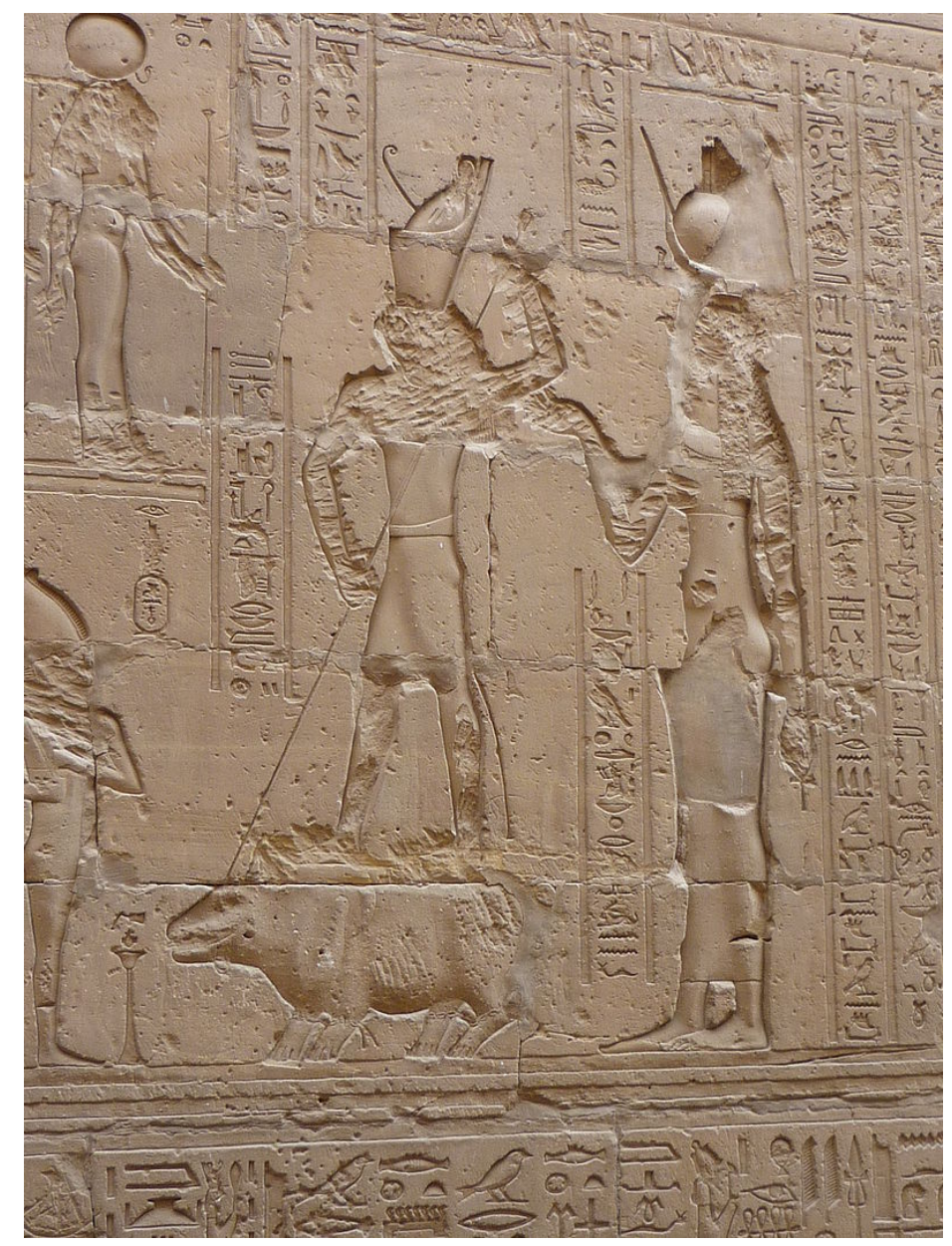

Horus spears Set, who appears in the form of a hippopotamus, as Isis looks on

During the Second Intermediate Period (1650-1550 BCE), a group of Near Eastern peoples, known as the Hyksos (literally, "rulers of foreign lands") gained control of Lower Egypt, and ruled the Nile Delta, from Avaris. They chose Set, originally Upper Egypt's chief god, the god of foreigners and the god they found most similar to their own chief god, Hadad, as their patron. Set then became worshiped as the chief god once again. The Hyksos King Apophis is recorded as worshiping Set exclusively, as described in the following passage:

[He] chose for his Lord the god Seth. He did not worship any other deity in the whole land except Seth. 
- Papyrus Sallier 1 (Apophis and Sekenenre)( Gardiner, ed. (1932). Papyrus

Sallier 1 (Apophis and Sekenenre). 1.2-3.)

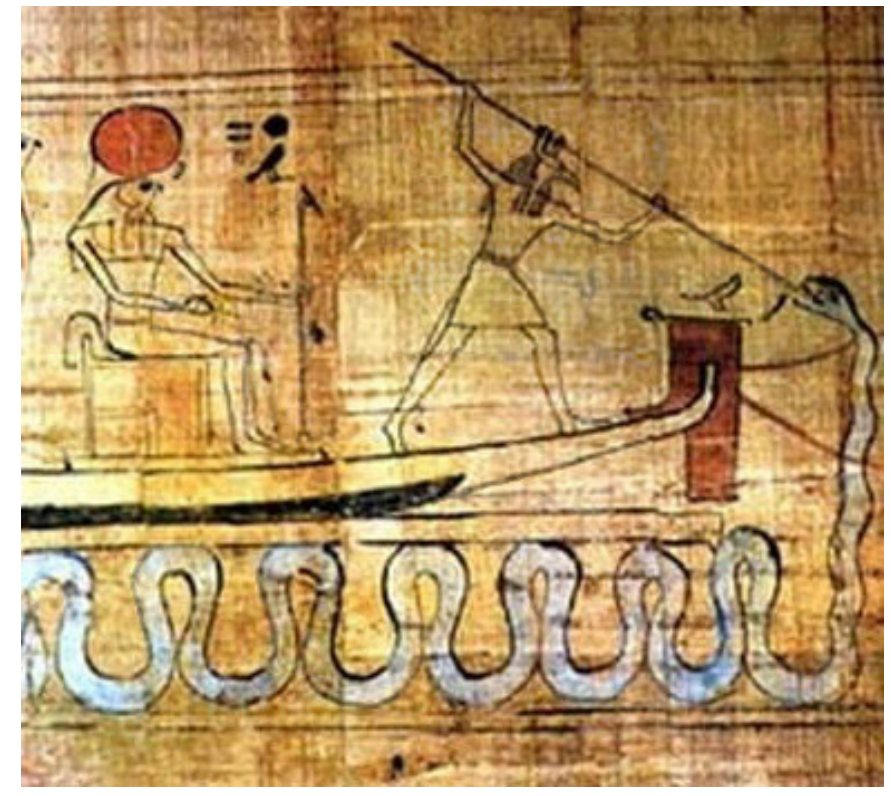

Set spears Apep

When, c. $1522 \mathrm{BCE}$, Ahmose I overthrew the Hyksos and expelled them, Egyptians' attitudes towards Asiatic foreigners became xenophobic, and royal propaganda discredited the period of Hyksos rule. The Set cult at Avaris flourished, nevertheless, and the Egyptian garrison of Ahmose stationed there became part of the priesthood of Set. 


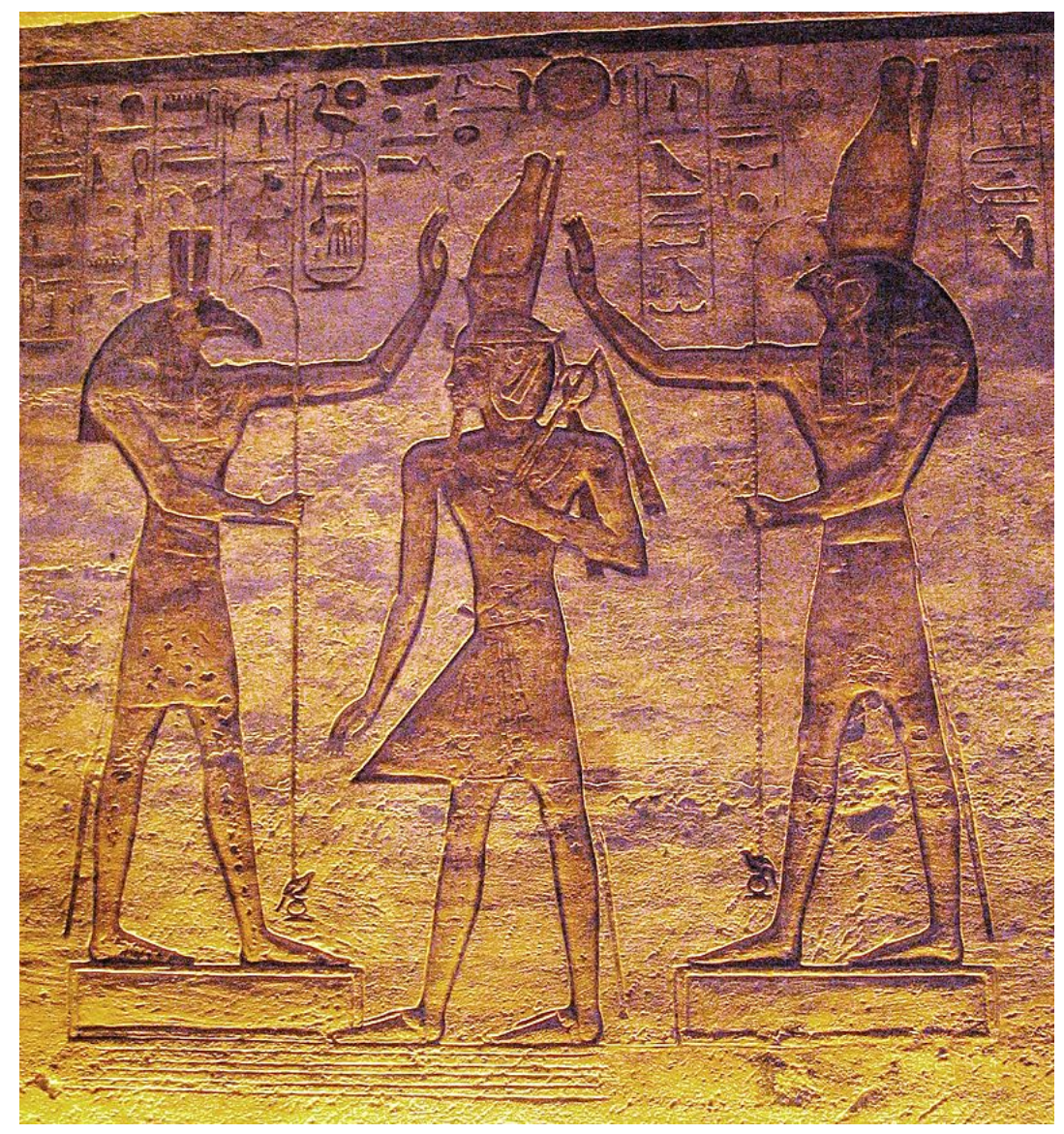

Set and Horus adore Ramesses in the small temple at Abu Simbel.

Set also became associated with foreign gods during the New Kingdom, particularly in the delta. Set was also identified by the Egyptians with the Hittite deity Teshub, who, like Set, was a storm god.

According to Herman te Velde, the demonization of Set took place after Egypt's conquest by several foreign nations in the Third Intermediate and Late Periods. Set, who had traditionally been the god of foreigners, thus also became associated with foreign oppressors, including the Assyrian and Persian empires (te Velde 1967, pp.138-140).It was during this time that Set was particularly vilified, and his defeat by Horus widely celebrated. 


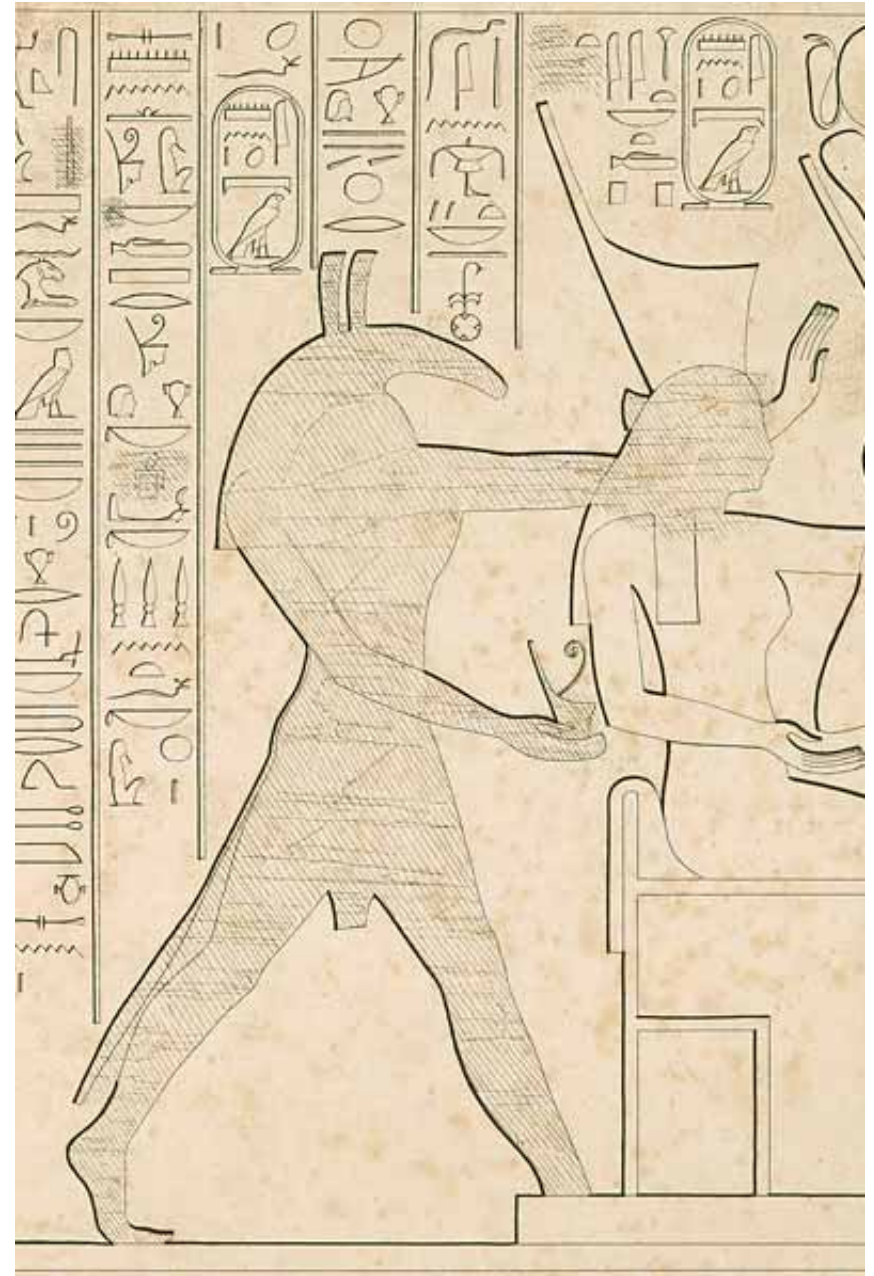

Set on a late New Kingdom relief from Karnak: his figure was erased during his demonization.

Set's negative aspects were emphasized during this period. Set was the killer of Osiris, having hacked Osiris' body into pieces and dispersed it so that he could not be resurrected.

Nevertheless, throughout this period, in some outlying regions of Egypt, Set was still regarded as the heroic chief deity.

By the way, the table below is Chinese character 夕 $(\mathrm{Xi})$ : 


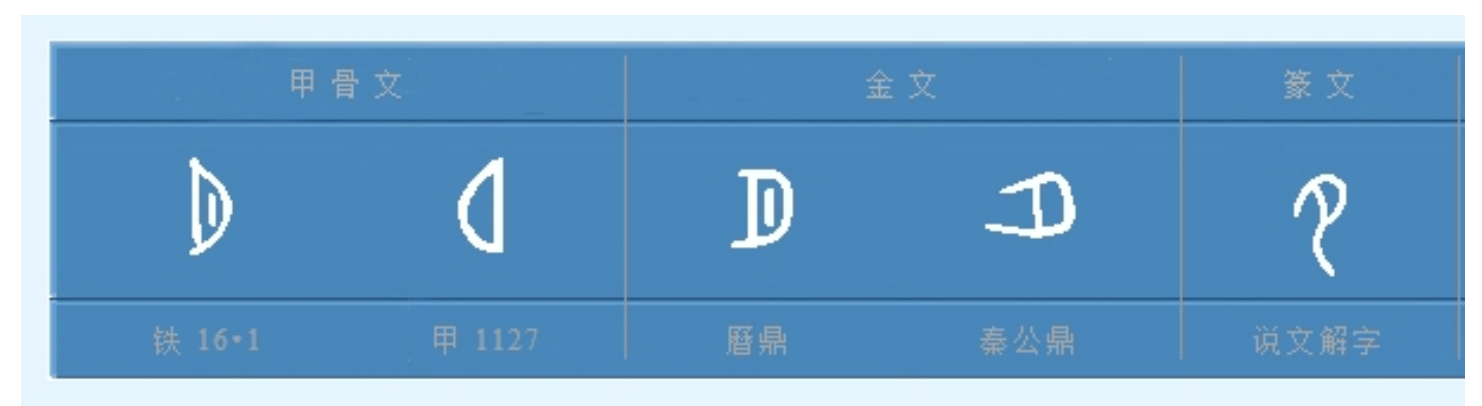

The prototype of “夕”

So from the above, we can get a hypothesis that the beast Xi(夕) is Set with Chinese characteristic.

On the first day there will be a holy convocation, and on the seventh day there will be a holy convocation for you. You must do no work of any kind on them, only what every person will eat that alone may be prepared for you. (Exodus 12:16 NET)

The Israelites who were in Jerusalem observed the Feast of Unleavened Bread for seven days with great joy. The Levites and priests were praising the Lord every day with all their mighty. (2Chronicles 30:21 NET)

On the first day and seventh day of Passover, the Israel will not work and have holy convocations to worship God. In China, from the first to the fifteenth day of the new year, people usually will not work and enjoy the Spring Festival holiday and spend time with family and have a good rest for the coming year. Especially, on the first day, all the family members will hang out and go to the parks and the temple fairs. In some places of China and the Chinatown overseas, they have dragon-lion dancing performance and other folk-custom performances. The Book of Rites-Yueling,( 礼记. 月令) “The king prays for the coming new year at the temple, ancestral hall, and in front of the door. The twelfth month is 
the time to worship the ancestors, and is the time for the people to have a rest."

"Instruct the people that each man and each woman is to request from his or her neighbor items of silver and gold" (Exodus 11:2 NET). "Now the Israelites had done as Moses told them they had requested from the Egyptians silver and gold items and clothing" (Exodus 12:35 NET).

After the first night of Passover, all the Israelites came out and asked their neighbors and the Egyptian for their property like gold, silver and clothing. In the Bible, they took the property from the Egyptian and carried it with them to the promised land in which they can build their own houses and communities. In China, from the second day of the Spring Festival which is the first day of the new year, every family will visit their kin and relatives, and the young children will get gift money from the elder. The gift money origins from the money used for witchcraft "Yasheng" in Han Dynasty which was used to drive away the evil spirits and pray for blessing. Nowadays, the traditional gift money is always put in the red envelope, which is also called lucky money for people believe the gift money can bring good luck to both the giver and receiver. 


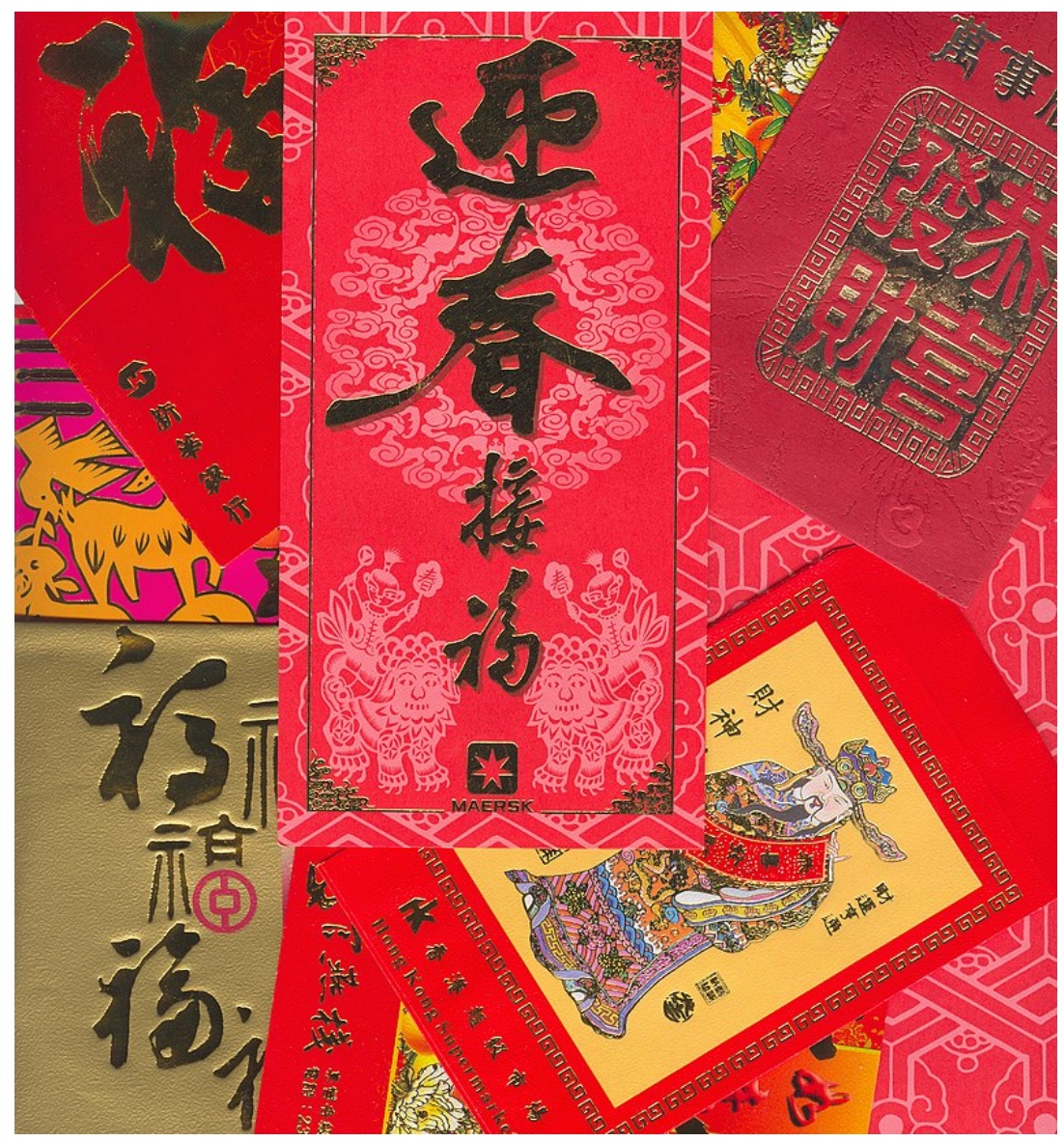

These are contemporary red envelope designs in Hong Kong circa 2000.

The divine right of kings, divine right, or God's mandate is a political and religious doctrine of royal and political legitimacy. It stems from a specific metaphysical framework in which the king (or queen) is preselected as an heir prior to his birth; by pre-selecting the king's physical manifestation, the governed populace actively (rather than merely passively) hands the metaphysical selection of the king's soul - which will inhabit the body and thereby rule them - over to God. In this way, the "divine right" originates as a metaphysical act of humility or submission towards the Godhead. Consequentially, it asserts that a monarch (e.g. a king) is subject to no earthly authority, deriving the right to rule directly from a divine authority, like the monotheist will of God. The monarch is thus not subject to the will of his people, of 
the aristocracy, or of any other estate of the realm. It implies that only divine authority can judge an unjust monarch and that any attempt to depose, dethrone or restrict their powers runs contrary to God's will and may constitute a sacrilegious act. It is often expressed in the phrase "by the Grace of God", attached to the titles of a reigning monarch; although this right does not make the monarch the same as a sacred king. The divine right has been a key element for legitimising many absolute monarchies.

Outside of Christianity, kings were often seen as either ruling with the backing of heavenly powers or perhaps even being divine beings themselves. However, the Christian notion of a divine right of kings is traced to a story found in 1 Samuel, where the prophet Samuel anoints Saul and then David as mashiach or king over Israel. The anointing is to such an effect that the monarch became inviolable, so that even when Saul sought to kill David, David would not raise his hand against him because "he was the Lord's anointed".

The Mandate of Heaven (Chinese: 天 命 ; pinyin: Tiānming; WadeGiles: T'ien-ming, literally "Heaven's will") is a Chinese political and religious teaching used since ancient times to justify the rule of the King or Emperor of China. According to this belief, Heaven (天, Tian) - which embodies the natural order and will of the universe - bestows the mandate on a just ruler of China, the "Son of Heaven" of the "Celestial Empire". If a ruler was overthrown, this was interpreted as an indication that the ruler was unworthy, and had lost the mandate. It was also a common belief that natural disasters such as famine and flood were divine retributions bearing signs of Heaven's displeasure with the 
ruler, so there would often be revolts following major disasters as the people saw these calamities as signs that the Mandate of Heaven had been withdrawn(Szczepanski, Kallie. "What Is the Mandate of Heaven in China?". About Education. Retrieved December 4, 2015.).

The Mandate of Heaven does not require a legitimate ruler to be of noble birth, depending instead on the just and able performance of the rulers and their heirs. Dynasties such as the Han and Ming dynasties were founded by men of common origins, but they were seen as having succeeded because they had gained the Mandate of Heaven. The concept is in some ways similar to the European concept of the divine right of kings; however, unlike the European concept, it does not confer an unconditional right to rule. Intrinsic to the concept of the Mandate of Heaven was the right of rebellion against an unjust ruler. The Mandate of Heaven was often invoked by philosophers and scholars in China as a way to curtail the abuse of power by the ruler, in a system that had few other checks. Chinese historians interpreted a successful revolt as evidence that Heaven had withdrawn its mandate from the ruler. Throughout Chinese history, times of poverty and natural disasters were often taken as signs that heaven considered the incumbent ruler unjust and thus in need of replacement. 


\section{The Dynastic Cycle}

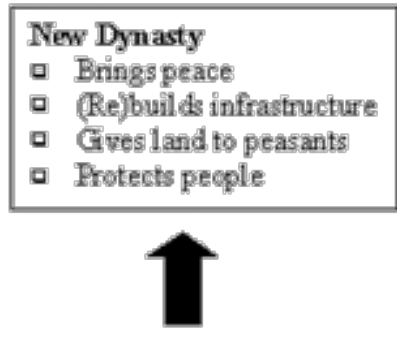

New Dynasty claims Mandate of Heaven

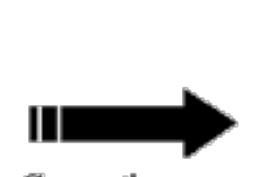

Generations go by, New Dynasty becomes.
Old Dynasty

a Taxes people too much

- Stops protecting people

- Lets infrastructure decay

- Treats people unfarity

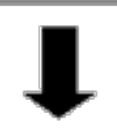

Old Dynasty loses

Mandate of Heaven

\section{Problems \\ - Floods, earthquakes, etc. \\ - Peasant rewdt \\ - Invaders attack empire \\ a Bandits raid countryside}

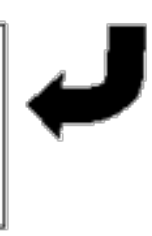

A brief flow chart describing the dynastic cycles in Imperial China on claiming to withdrawing the Mandate of Heaven

The concept of the Mandate of Heaven was first used to support the rule of the kings of the Zhou dynasty (1046-256 BCE), and legitimize their overthrow of the earlier Shang dynasty (1600-1069 BCE). It was used throughout the history of China to legitimize the successful overthrow and installation of new emperors, including by non-Han Chinese monarchs such as the Qing (1636-1912).

Chinese historians interpreted a successful revolt as evidence that the Mandate of Heaven had passed. In China, the right of rebellion against an unjust ruler has been a part of political philosophy ever since the Zhou dynasty, and the successful rebellion was interpreted by Chinese historians as evidence that divine approval had passed on to the successive dynasty. The Right of Rebellion is not coded into any official law. Rather, rebellion is always outlawed and severely punished; but is still a positive right grounded in the Chinese moral system. Often, it is used as a justification for actions to overthrow a previous dynasty after a 
rebellion has been successful and a new dynastic rule has been established. Since the winner is the one who determines who has obtained the Mandate of Heaven and who has lost it, some Chinese scholars consider it to be a sort of Victor's justice, best characterized in the popular Chinese saying "The winner becomes king, the loser becomes outlaw" (Chinese: “成者为王，败者为寇”). Due to this, it is considered that Chinese historical accounts of the fall of a dynasty and the rise of a new one must be handled with caution. Chinese traditional historical compilation methods produce accounts that tend to fit their account to the theory, emphasizing aspects tending to prove that the old dynasty lost the Mandate of Heaven and the new one gained it, and deemphasizing other aspects.

In Judaism, God has been conceived in a variety of ways ( James Kugel, "'The God of Old, Inside the Lost World of the Bible" (New York: Simon \& Schuster, 2003)).Traditionally, Judaism holds that $\mathrm{YHWH}$, the God of Abraham, Isaac, and Jacob and the national god of the Israelites, delivered the Israelites from slavery in Egypt, and gave them the Law of Moses at biblical Mount Sinai as described in the Torah. According to the rationalist stream of Judaism articulated by Maimonides, which later came to dominate much of official traditional Jewish thought, God is understood as the absolute one, indivisible, and incomparable being who is the ultimate cause of all existence. Traditional interpretations of Judaism generally emphasize that God is personal yet also transcendent, while some modern interpretations of Judaism emphasize that God is a force or ideal(http://www.myjewishlearning.com/article/modern-jewish-views-of-god). 
The names of God used most often in the Hebrew Bible are the Tetragrammaton (YHWH Hebrew: יהוה) and Elohim. Other names of God in traditional Judaism include El Shaddai and Shekhinah.

The name of God used most often in the Hebrew Bible is the Tetragrammaton (YHWH Hebrew: יהוה). Jews traditionally do not pronounce it, and instead refer to God as HaShem, literally "the Name". In prayer the Tetragrammaton is substituted with the pronunciation Adonai, meaning "My Lord".

The national god of the Iron Age kingdoms of Israel and Judah was Yahweh(Miller, Patrick $\quad$ D. (2000). ).The precise origins of this god are disputed, although they reach back to the early early Iron Age and even the late Bronze Age(Miller, Patrick D. (2000) and Smith, Mark S. (2010) ).The name may have begun as an epithet of El, (Miller, Patrick D. (2000). )head of the Bronze Age Canaanite pantheon, but earlier mentions are in Ancient Egyptian texts that place God among the nomads of the southern Transjordan(Römer, Thomas (2015).).

After evolving from its monolatristic roots( John M. Duffey (2013). ), Judaism became strictly monotheistic. No consensus has been reached by academics on the origins of monotheism in ancient Israel, but "Yahweh clearly came out of the world of the gods of the Ancient Near East(Smith, Mark S.; Miller, Patrick D. (2002).)."

The worship of multiple gods (polytheism) and the concept of God having multiple persons (as in the doctrine of Trinity) are equally unimaginable in Judaism. The idea of God as a duality or trinity is heretical in Judaism - it is considered akin to polytheism. 
God, the Cause of all, is one. This does not mean one as in one of series, nor one like a species (which encompasses many individuals), nor one as in an object that is made up of many elements, nor as a single simple object that is infinitely divisible. Rather, God is a unity unlike any other possible unity. (Maimonides, 13 Principles of Faith, Second Principle)( Maimonides, 13 principles of faith, Second Principle)

Since, according to the mystical conception, all of existence emanates from God, whose ultimate existence is not dependent on anything else, some Jewish sages perceived God as interpenetrating the universe, which itself has been thought to be a manifestation of God's existence. According to this line of theological speculation, Judaism can be regarded as being compatible with panentheism, while always affirming genuine monotheism.

In modern articulations of traditional Judaism, God has been speculated to be the eternal, omnipotent and omniscient creator of the universe, and the source of morality. God has the power to intervene in the world. Maimonides describes God in this fashion: "The foundation of all foundations and the pillar of wisdom is to know that there is a Primary Being who brought into being all existence. All the beings of the heavens, the earth, and what is between them came into existence only from the truth of His being(Mishneh Torah, book HaMadda', section Yesodei haTorah, chapter 1:1)." 


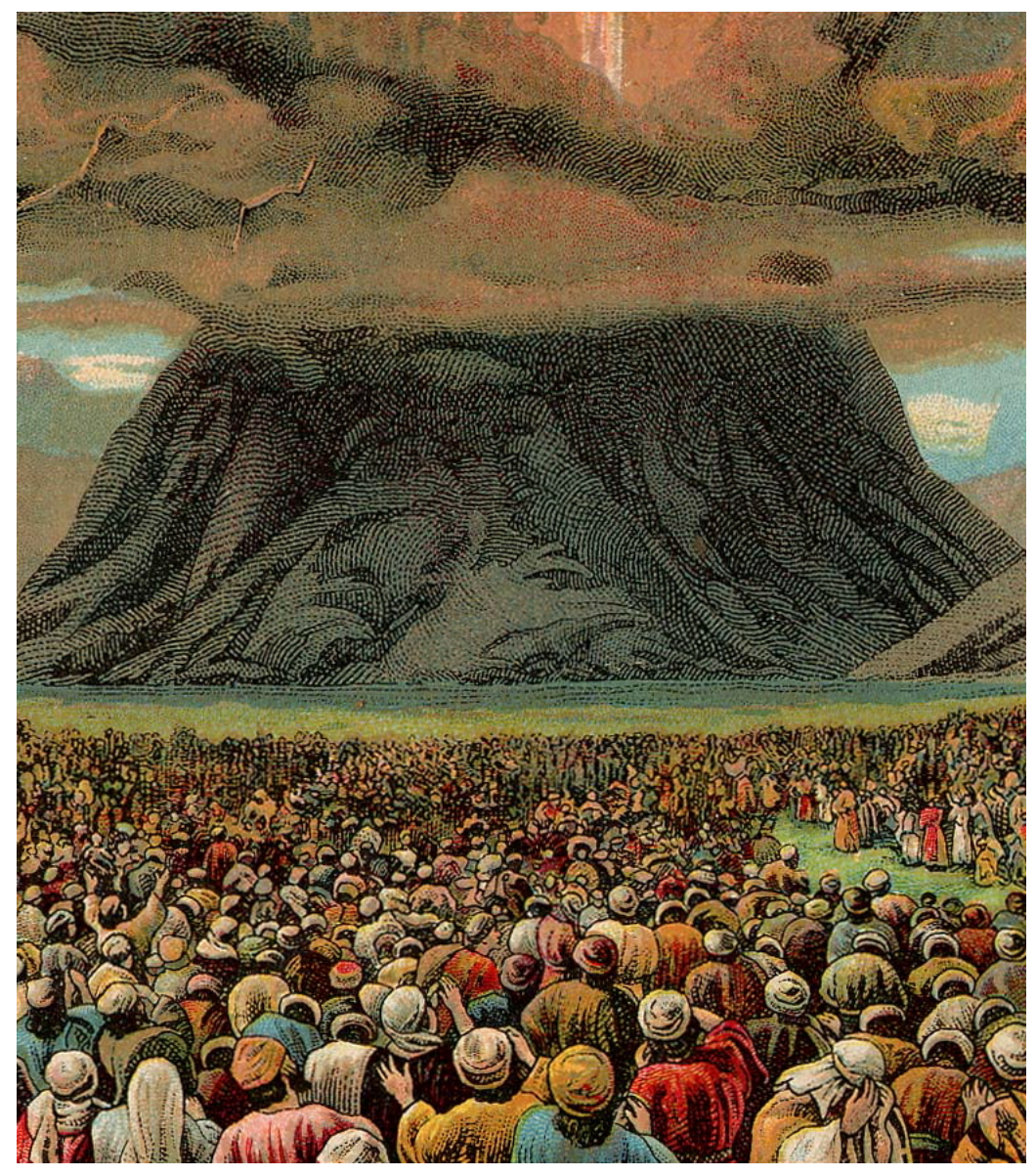

The mass revelation at Mount Horeb in an illustration from a Bible card published by the Providence Lithograph Company, 1907

Jews often describe God as omniscient("Jewish Beliefs about God" inC/JEEP Curriculum Guide American Jewish Committee), although some prominent medieval Jewish philosophers held that God does not have complete foreknowledge of human acts. Gersonides, for example, argued that God knows the choices open to each individual, but that God does not know the choices that an individual will make( Jacobs, Louis (1990). ).Abraham ibn Daud believed that God was not omniscient or omnipotent with respect to human action(Guttmann, Julius (1964). ).

Jews often describe God as omnipotent, and see that idea as rooted in the Hebrew Bible("Jewish Beliefs about God" inC/JEEP Curriculum Guide American Jewish Committee).Some modern Jewish theologians have argued that God 
is not omnipotent, however, and have found many biblical and classical sources to support this view(Geoffrey Claussen, "God and Suffering in Heschel's Torah Min Ha-Shamayim". Conservative Judaism 61, no. 4 (2010), p. 17).

Shangdi (Chinese: 上 帝 ; pinyin: Shàngdi;), also written simply, "Emperor" (Chinese: 帝; pinyin: Di), is the Chinese term for "Supreme Deity" or "Highest Deity" in the theology of the classical texts, especially deriving from Shang theology and finding an equivalent in the later Tian ("Heaven" or "Great Whole") of Zhou theology( Eno (2008), p. 70).

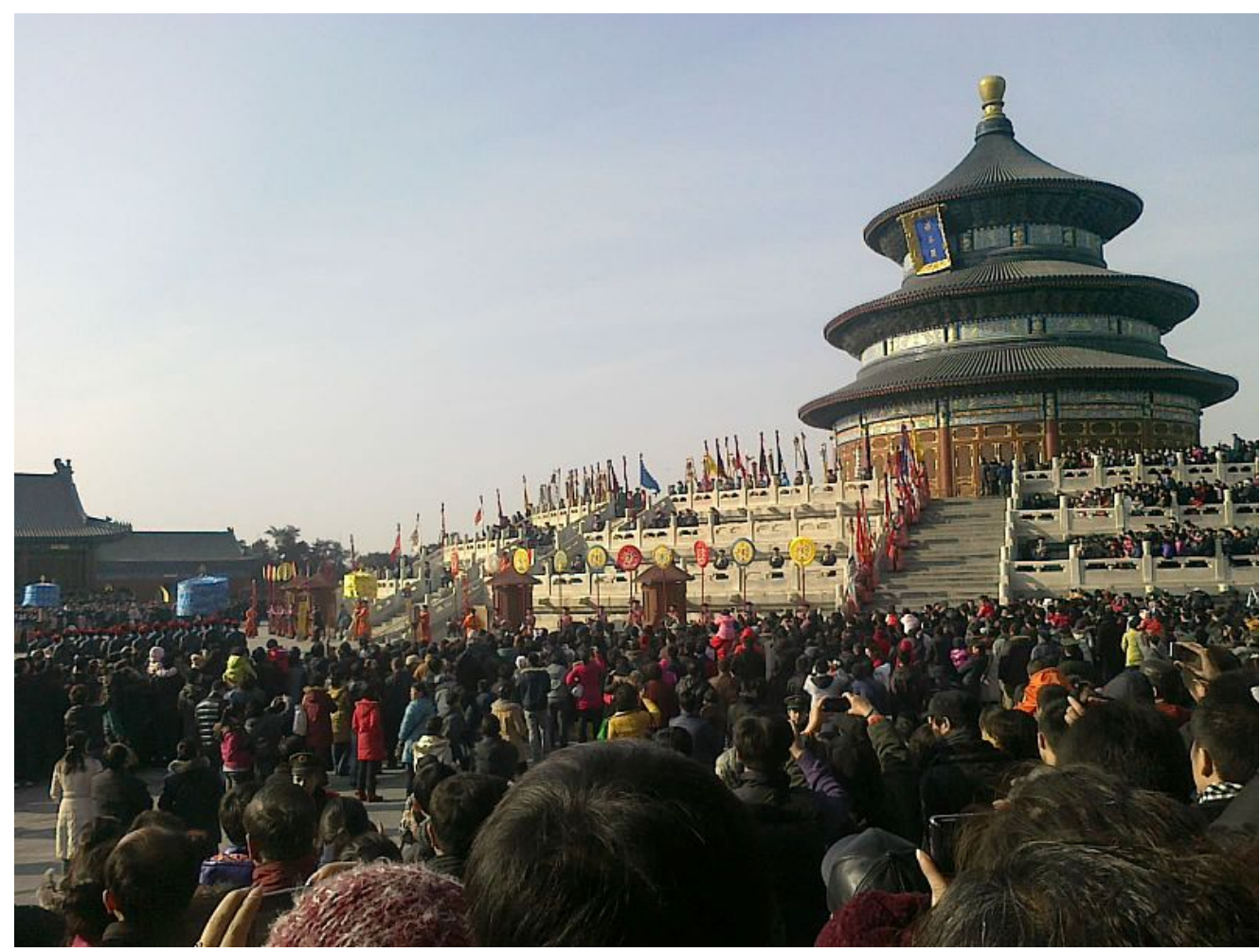

Annual heavenly sacrifice (祭天 jitiōn) in honour of the Highest Deity the Heavenly Ruler (皇天上帝 Huángtiān Shàngdi) is held at the Temple of Heaven in Beijing. State pomp and a variety of Confucian religious groups have contributed in the reviving of worship of the Highest Deity in the 2000s.

Although in Chinese religion the usage of "Tian"(天) to refer to the absolute God of the universe is predominant, "Shangdi"( 上帝） 
continues to be used in a variety of traditions, including certain philosophical schools(Chang (2000).), certain strains of Confucianism(Huang (2007), p. 457.), some Chinese salvationist religions and Chinese Protestant Christianity. In addition, it is common to use such term among contemporary and secular Chinese, Hong Kong, and Taiwanese societies typically for a singular universal deity and a nonreligion translation for the God in Christianity.

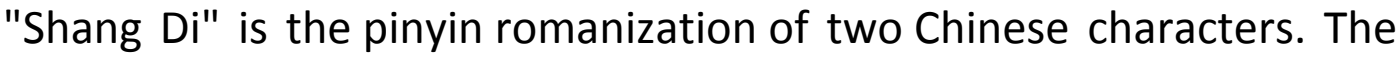
first - 上, Shàng - means "high", "highest", "first", "primordial"; the second - 帝, Dì - is typically considered as shorthand for huangdi (皇帝) in modern Chinese, the title of the emperors of China first employed by Qin Shi Huang, and is usually translated as "emperor". The word itself is derived from Three "Huang" and Five "Di", including Yellow Emperor (Huangdi 黄帝), the mythological originator of the Chinese civilization and the ancestor of the Chinese race. However, 帝 refers to the High God of Shang, thus means "deity" (manifested god)(Chang (2000).). Thus, the name Shangdi should be translated as "Highest Deity", but also has the implied meaning of "Primordial Deity" or "First Deity" in Classical Chinese. The deity preceded the title and the emperors of China were named after him in their role as Tianzi(天子), the sons of Heaven. In the classical texts the highest conception of the heavens is frequently identified with Shang $\mathrm{Di}$, who is described somewhat anthropomorphically. $\mathrm{He}$ is also associated with the pole star. The conceptions of the Supreme Ruler (Shang Di) and of the Sublime Heavens (Huang-t'ien) afterward coalesce or absorb each other(Clemen, Carl (2005).). 


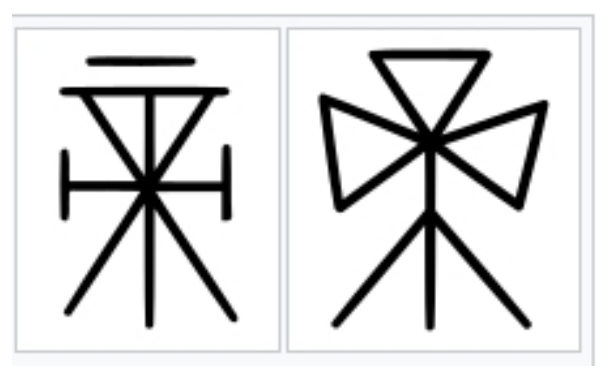

Shang oracular script graphs for 帝 Dì, the supreme God as the celestial pole(Eno (2008), p. 74.).

In the later Shang and Zhou dynasties, Shangdi was conflated with Heaven ( 天 , Tiān)( "Shangdi", Encyclopædia Britannica, 2011). The Duke of Zhou justified his clan's usurpation through the concept of the Mandate of Heaven, which proposed that the protection of Shangdi was not connected to their clan membership but by their just governance. Shangdi was not just a tribal but instead an unambiguously good moral force, exercising its power according to exacting standards(Book of Documents). It could thus be lost and even "inherited" by a new dynasty, provided they upheld the proper rituals.

Nonetheless, the connection of many rituals with the Shang clan meant that Shang nobles continued to rule several locations (despite their rebellions) and to serve as court advisors and priests. The Duke of Zhou even created an entire ceremonial city along strict cosmological principals to house the Shang aristocracy and the nine tripods representing Huaxia sovereignty; the Shang were then charged with maintaining the Rites of Zhou. Likewise, the Shang's lesser houses, the shi knightly class, developed directly into the learned Confucian gentry and scholars who advised the Zhou rulers on courtly etiquette and ceremony("Chinese Philosophy". China Renmin Univ., 2006.). 
The Confucian classics carried on and ordered the earlier traditions, including the worship of Shangdi. All of them include references:

\section{Occurrences of Shangdi in the Five Classics}

\begin{tabular}{|l|l|l|l|}
\hline Chinese Name & Pinyin & \multicolumn{1}{|c|}{ English Name } & Occurrences \\
\hline 書經 & Shujing & Classic of History & 32 times \\
\hline 詩經 & Shijing & Classic of Poetry & 24 times \\
\hline 禮記 & Liji & Classic of Rites & 20 times \\
\hline 春秋 & Chunqiu & Spring and Autumn Annals & 8 times \\
\hline 易經 & Yijing & Classic of Changes & 2 times \\
\hline
\end{tabular}

The Four Books mention Shangdi as well but, as it is a later compilation, the references are much more sparse and abstract. Shangdi appears most commonly in earlier works: this pattern may reflect increasing rationalization of Shangdi over time, the shift from a known and arbitrary tribal god to a more abstract and philosophical concept(The Book of Documents and Zuo Zhuan), or his conflation and absorption by other deities.

Under Shangdi or his later names, the deity received sacrifices from the ruler of China in every Chinese dynasty annually at a great Temple of Heaven in the imperial capital. Following the principles of Chinese geomancy, this would always be located in the southern quarter of the city(For instance, the Classic of History records the Duke of Zhou building an altar in the southern part of Luo.). During the ritual, a completely healthy bull would be slaughtered and presented as an animal sacrifice to Shangdi(Although the Duke of Zhou is presented as sacrificing two.). The Book of Rites states the sacrifice should occur on the "longest day" on a round-mound altar. The altar would have three tiers: the highest for Shangdi and the Son of 
Heaven; the second-highest for the sun and moon; and the lowest for the natural gods such as the stars, clouds, rain, wind, and thunder.

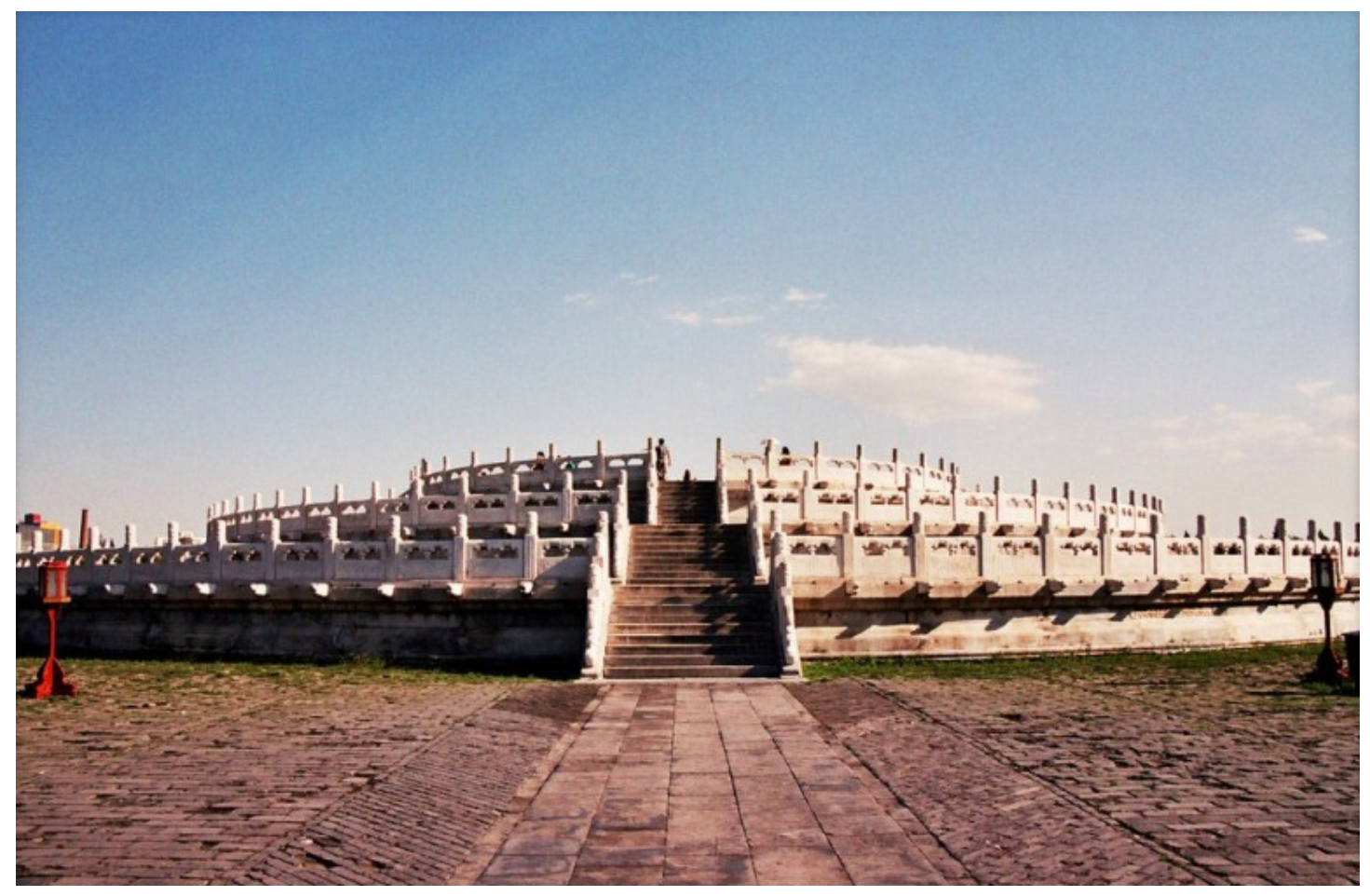

Sacred altar at the Temple of Heaven, Beijing

It is important to note that Shangdi is never represented with either images or idols. Instead, in the center building of the Temple of Heaven, in a structure called the "Imperial Vault of Heaven", a "spirit tablet" (神 位, shénwèi) inscribed with the name of Shangdi is stored on the throne, Huangtian Shangdi (皇天上帝). During an annual sacrifice, the emperor would carry these tablets to the north part of the Temple of Heaven, a place called the "Prayer Hall For Good Harvests", and place them on that throne("JSDJ". Archived from the original on 2005-12-14.). 


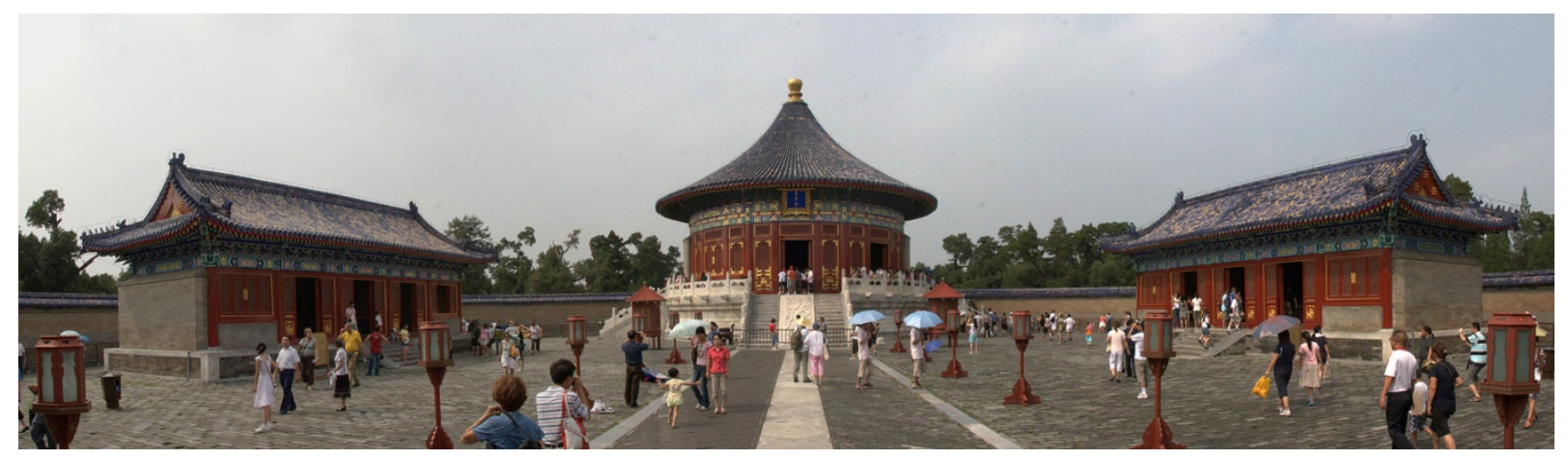

Panorama from the opposite view of the Imperial Vault of Heaven

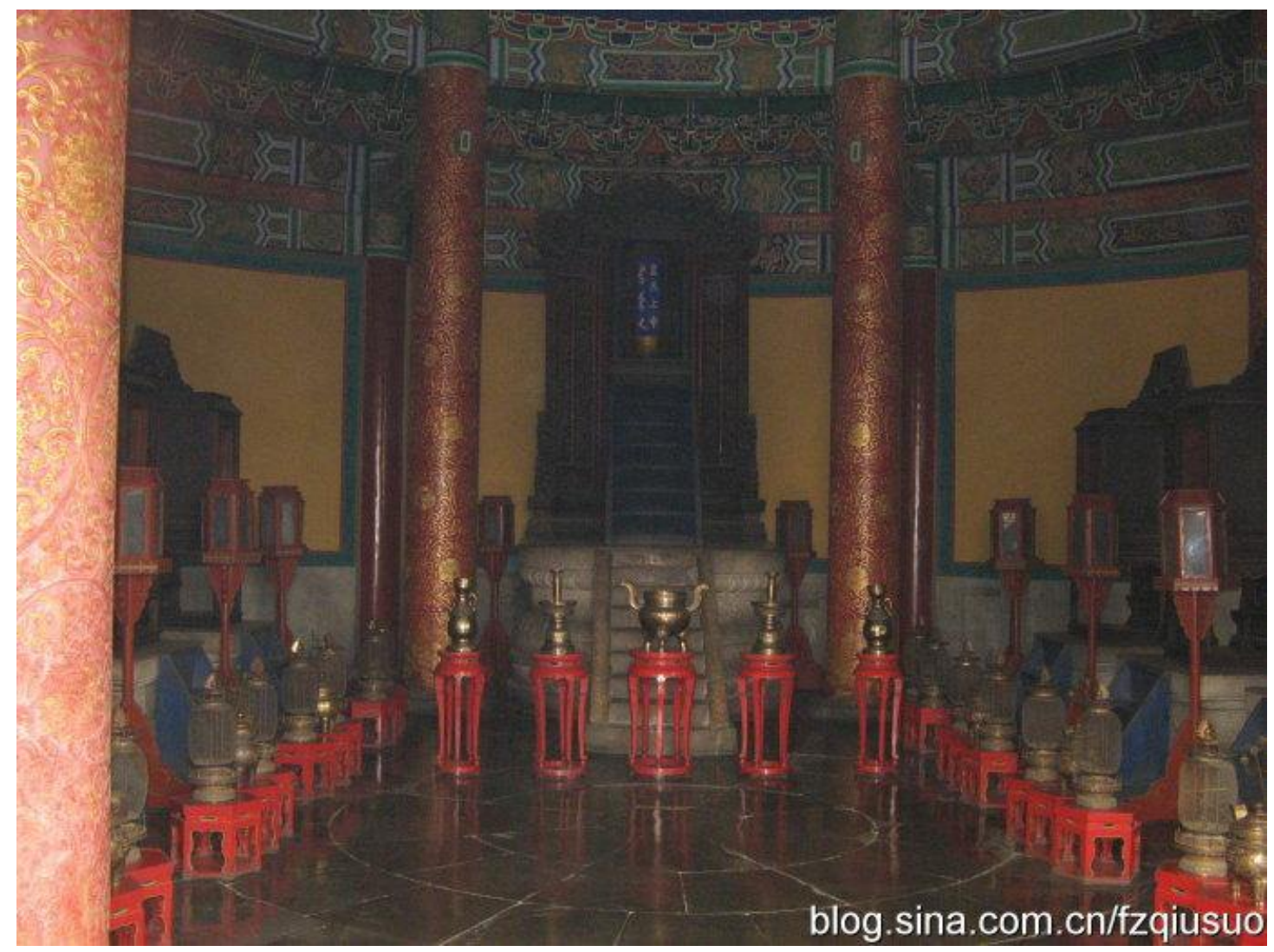

A "spirit tablet" (神位, shénwèi) inscribed with the name of Huangtian Shangdi (皇天 上帝) in the "Imperial Vault of Heaven" 


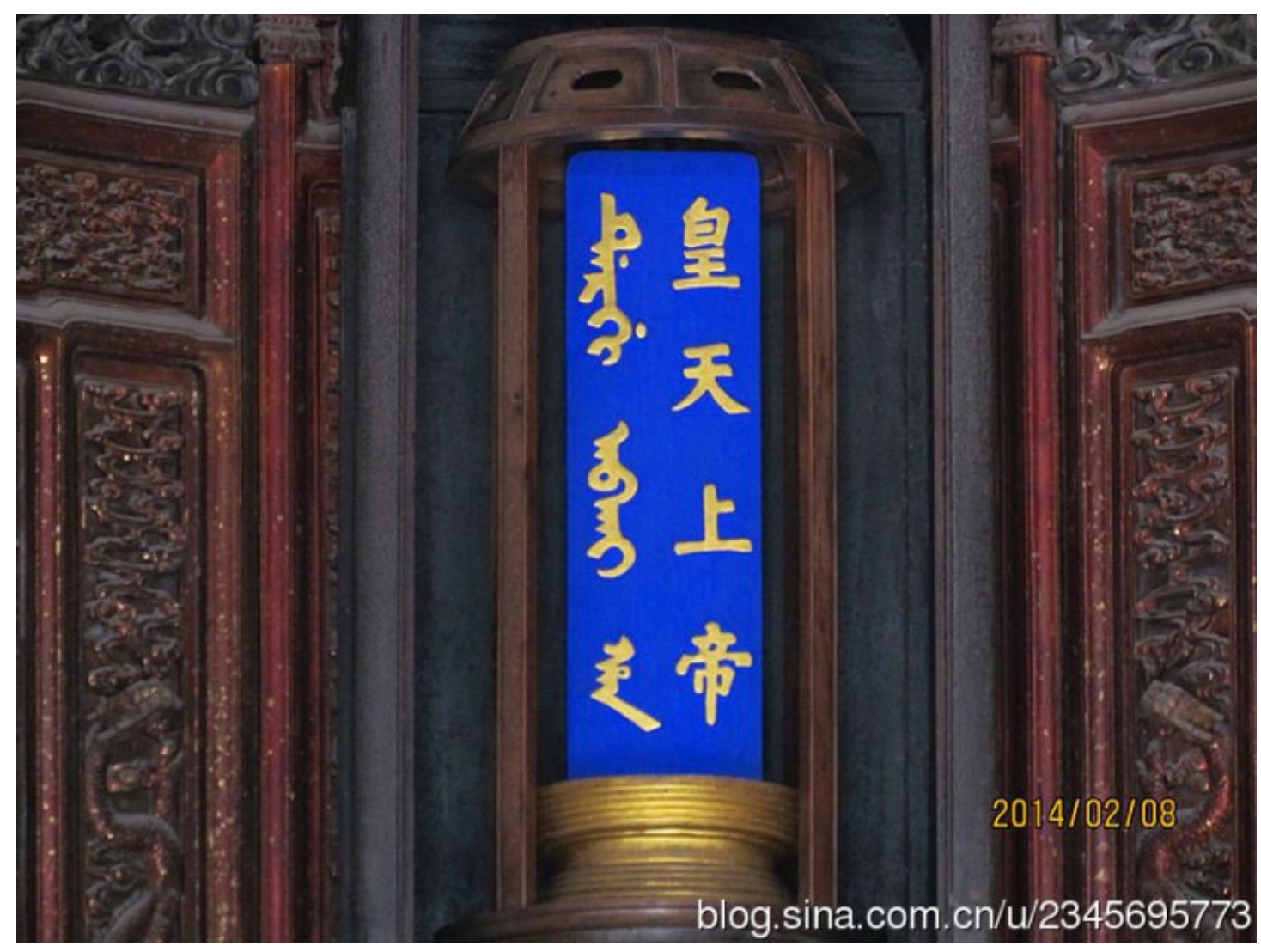

The magnification of Huangtian Shangdi(皇天上帝)

Tiān (天) is one of the oldest Chinese terms for heaven and a key concept in Chinese mythology, philosophy, and religion. During the Shang dynasty (17-11th centuries BCE), the Chinese referred to their supreme god as Shàngdi (上帝, "Lord on High") or Dì (帝,"Lord"). During the following Zhou dynasty, Tiān became synonymous with this figure. Heaven worship was, before the 20th century, an orthodox state religion of China.

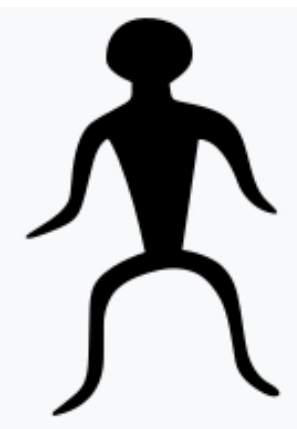


Chinese Bronze script character for tiān(天).

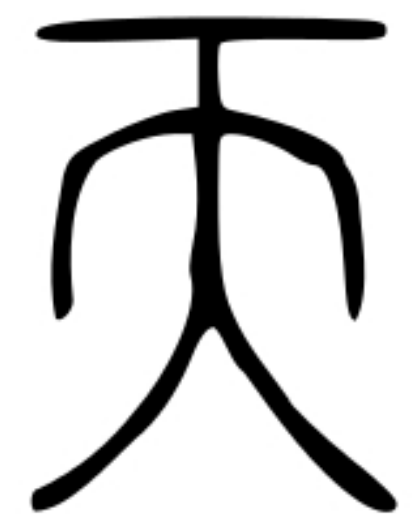

Chinese Seal script for tiān 天"heaven"

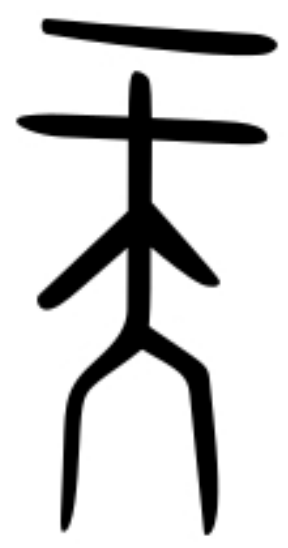

Chinese Oracle script for tiān 天"heaven"

The Modern Standard Chinese pronunciation of 天 "sky, heaven; heavenly deity, god" is tiān in level first tone.

Tiān 天 reconstructions in Middle Chinese (ca. 6th-10th centuries CE) include t'ien (Bernhard Karlgren), $t^{\prime} i \varepsilon n$ (Zhou Fagao), $t^{h} \varepsilon n>t^{h}$ ian (Edwin G. Pulleyblank), and then (William H. Baxter, Baxter \& Sagart). Reconstructions in Old Chinese (ca. 6th-3rd centuries BCE) include *t'ien (Karlgren), *t'en (Zhou), *hlin (Baxter), *thîn (Schuessler), and *Isin (Baxter \& Sagart). 
The concept of Heaven (Tian, 天) is pervasive in Confucianism. Confucius had a deep trust in Heaven and believed that Heaven overruled human efforts. He also believed that he was carrying out the will of Heaven, and that Heaven would not allow its servant, Confucius, to be killed until his work was done(Analects 7.23). Many attributes of Heaven were delineated in his Analects.

Confucius honored Heaven as the supreme source of goodness:

The Master said, "Great indeed was Yao as a sovereign! How majestic was he! It is only Heaven that is grand, and only Yao corresponded to it. How vast was his virtue! The people could find no name for it. How majestic was he in the works which he accomplished! How glorious in the elegant regulations which he instituted!" (VIII, xix, tr. Legge 1893:214)

Confucius felt himself personally dependent upon Heaven (VI, xxviii, tr. Legge 1893:193): "Wherein I have done improperly, may Heaven reject me! may Heaven reject me!"

Confucius believed that Heaven cannot be deceived:

The Master being very ill, Zi Lu wished the disciples to act as ministers to him. During a remission of his illness, he said, "Long has the conduct of You been deceitful! By pretending to have ministers when I have them not, whom should I impose upon? Should I impose upon Heaven? Moreover, than that I should die in the hands of ministers, is it not better that I should die in the hands of you, my disciples? And though I may not get a great burial, shall I die upon the road?" (IX, xi, tr. Legge 1893:220-221)

Confucius believed that Heaven gives people tasks to perform to teach them of virtues and morality:

The Master said, "At fifteen, I had my mind bent on learning. At thirty, I stood firm. At forty, I had no doubts. At fifty, I knew the decrees of Heaven. At sixty, 
my ear was an obedient organ for the reception of truth. At seventy, I could follow what my heart desired, without transgressing what was right." (II, iv, tr. Legge 1893:146)

He believed that Heaven knew what he was doing and approved of him, even though none of the rulers on earth might want him as a guide:

The Master said, "Alas! there is no one that knows me." Zi Gong said, "What do you mean by thus saying - that no one knows you?" The Master replied, "I do not murmur against Heaven. I do not grumble against men. My studies lie low, and my penetration rises high. But there is Heaven - that knows me!" (XIV, XXXV, tr. Legge 1893:288-9)

Perhaps the most remarkable saying, recorded twice, is one in which Confucius expresses complete trust in the overruling providence of Heaven:

The Master was put in fear in Kuang. He said, "After the death of King Wen, was not the cause of truth lodged here in me? If Heaven had wished to let this cause of truth perish, then I, a future mortal, should not have got such a relation to that cause. While Heaven does not let the cause of truth perish, what can the people of Kuang do to me?" (IX, v and VII, xxii, tr. Legge 1893:217-8)

So from the above, we can get a hypothesis that God in Judaism and Shangdi(上帝) and Tian(天) are nearly the same. Besides, we can also get a hypothesis that the Christian notion of a divine right of kings resembles the Mandate of Heaven(天命).

Hou Ji (or Houji; Chinese: 后 稷 ; pinyin: Hòu Ji;) was a legendary Chinese culture hero credited with introducing millet to humanity during the time of the Xia dynasty("Hou Ji", China culture, 2008-02-01). Millet was the original staple grain of northern China, prior to the introduction of 
wheat. His name translates as Lord of Millet and was a posthumous namebestowed on him by King Tang, the first of the Shang dynasty. Houji was credited with developing the philosophy of Agriculturalism and with service during the Great Flood in the reign of Yao; he was also claimed as an ancestor of the Ji (姬)clan that became the ruling family of the Zhou dynasty(The Book of Chinese Poetry: Being the Collection of Ballads, Sagas, Hymns, and Other Pieces Known as the Shih Ching; Or, Classic of Poetry. K. Paul, Trench, Trübner. 1891. pp. 9).

Hou Ji's original name was Qi (弃), meaning "abandoned".

Two separate versions of his origin were common. In one version of Chinese mythology, he was said to have been supernaturally conceived when his mother Jiang Yuan, a previously barren wife of the Emperor $\mathrm{Ku}$, stepped into a footprint left by Shangdi(上帝), the supreme sky god of the early Chinese pantheon(Encyclopædia Britannica. "Hou Ji" and Shijing, III.2. Ode 295.). Another account simply make him one of Ku's four sons, each prophesied to father a family of emperors over China. This origin allowed his descendants to claim a lineage from the Yellow Emperor as well(China Knowledge. "Diku".).

He was held to have been repeatedly abandoned by his mother, but saved each time - in the street, by draft animals; in the forest, by woodcutters; on the ice, by a great bird. He later became famous for his luxuriant crops of beans, rice, hemp, gourds, and several kinds of millet and was credited with the introduction of the spring ritual sacrifice of fermented millet beer, roasted sheep, and the herb southernwood(Shijing, III.2. Ode 295.). 
In his own lifetime, he was restored to high office and honored by the Xia King with an ancestral name: in his case, Ji (姬, after the name of a river). He was granted or confirmed in his dominion over Tai. His son Buzhu (不窑)inherited his position at court but abandoned it and possibly agriculture as well to live among the Rong and Di barbarians around Xia(Sima Qian. Records of the Grand Historian.).

As mentioned above, he was later granted a posthumous name as well by the first Shang king Tang. Houji was also claimed as the ancestor of the Zhou ( 周 )royal family and honored in their Book of Songs: the Sheng Min ("Birth of Our People") is counted as one of the work's Great Hymns(Shijing, III.2. Ode 295.). The Zhou(周) ministers of agriculture were also titled "Houji"(后稷) in his honor("Hou Ji", China culture, 2008-0201.).

Although historians such as Sima Qian took a more rationalist approach to his life, making him a natural son of Emperor $\mathrm{Ku}$ and a regular official of the Xia court, Houji (后稷)was honored not just as a culture hero (Nelseon, Sarah M. Origins of Food Production In China.)but also as a patron god of abundant harvests(Encyclopædia Britannica. "Hou Ji" and Roberts. Chinese Mythology A to Z, 2nd Ed, p.70. 2009.).

And the image below is the prototype of Ji(姬): 


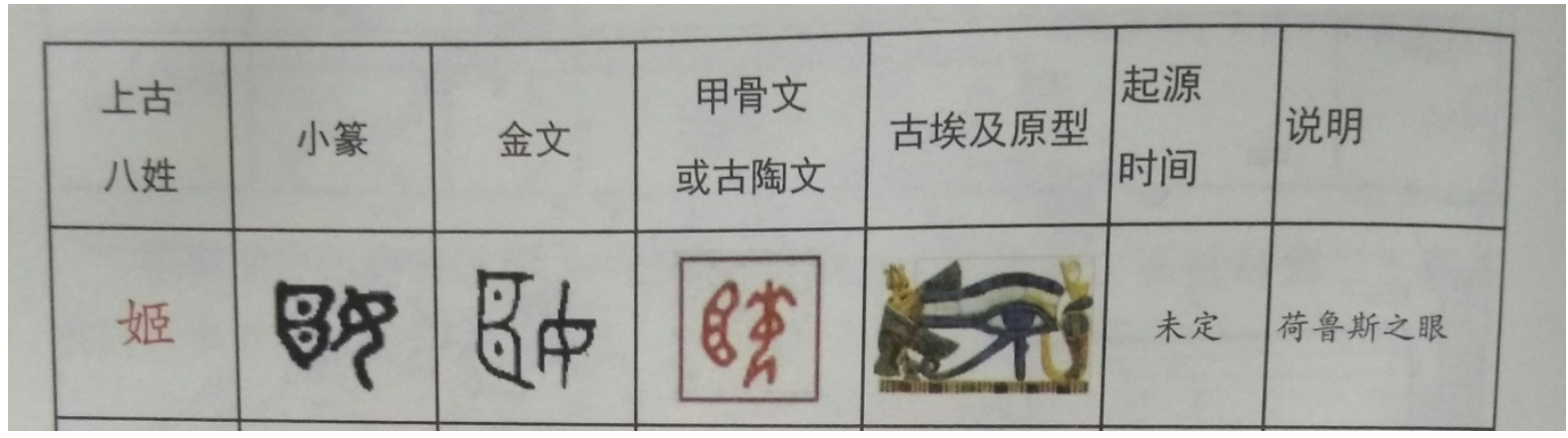

The prototype of Ji(姬)

And the image below is a seal of the First Dynasty of ancient Egypt, you can found the prototype of Zhou(周): 


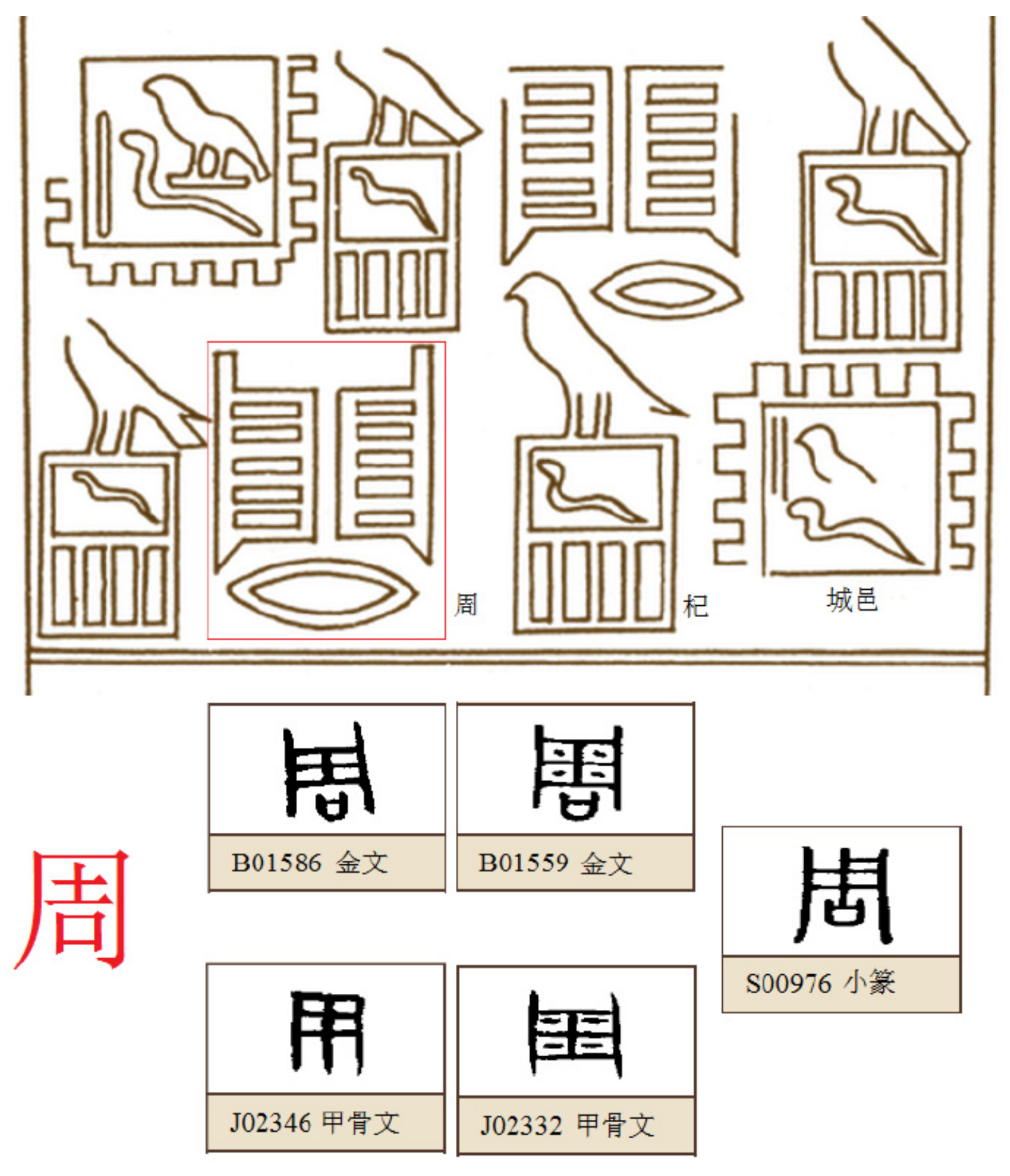

The Prototype of Zhou(周)

Hemaka was an important official during the long reign of the First Dynasty Egyptian pharaoh Den. Radiocarbon dating research undertaken during the 1950s suggested a date for Hemaka lifetime ca. 3100 BC( PARKER, R. A. (and R. J. Braidwood, Th. Jacobsen, S. Weinberg), Radiocarbon Dates and Their Implications in the Near and Middle Eastern Area, A Brief sic, in: Radiocarbon Dating. A Report on the Program to Aid in the Development of the Method of Dating, Assembled by Frederick Johnson, Memoirs of the Society for 
American Archaeology, Number 8, 1951, Published by The Society for American Archaeology, Salt Lake City, Utah, pp. 52-53 = Supplement to American Antiquity, Volume XVII, Number 1, Part 2, July 1951, pp. 52-53.). One of Hemaka's titles was that of "seal-bearer of the king of Lower Egypt"(Wilkinson, Toby A. H. Early Dynastic Egypt. p. 131. Routledge, 1999. ISBN 0-203-20421-2), effectively making him chancellor and second in power only to the king(Wilkinson, Toby A. H. Early Dynastic Egypt. p. 65. Routledge, 1999. ISBN 0-203-20421-2).

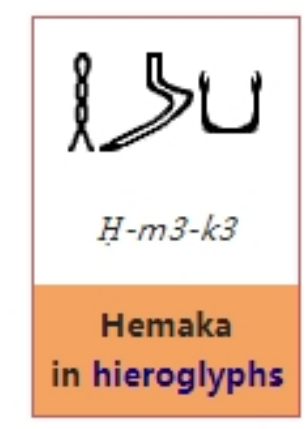

The tomb of his chancellor Hemaka is larger than the king's own tomb, and for years was mistakenly thought of as belonging to Den(Clayton, Peter A. Chronicle of the Pharaohs: The Reign-by-Reign Record of the Rulers and Dynasties of Ancient Egypt. p. 24. Thames \& Hudson. 2006. ISBN 0-500-28628-0). It was first excavated by Cecil Mallaby Firth in 1931 and work was continued under the supervision of Walter Bryan Emery starting in 1936(W. B. Emery: Excavations at Saqqara: the tomb of Hemaka, Cairo: Government Press and Wilkinson, Toby A. H. Early Dynastic Egypt. p. 9. Routledge, 1999. ISBN 0-203-20421-2). 


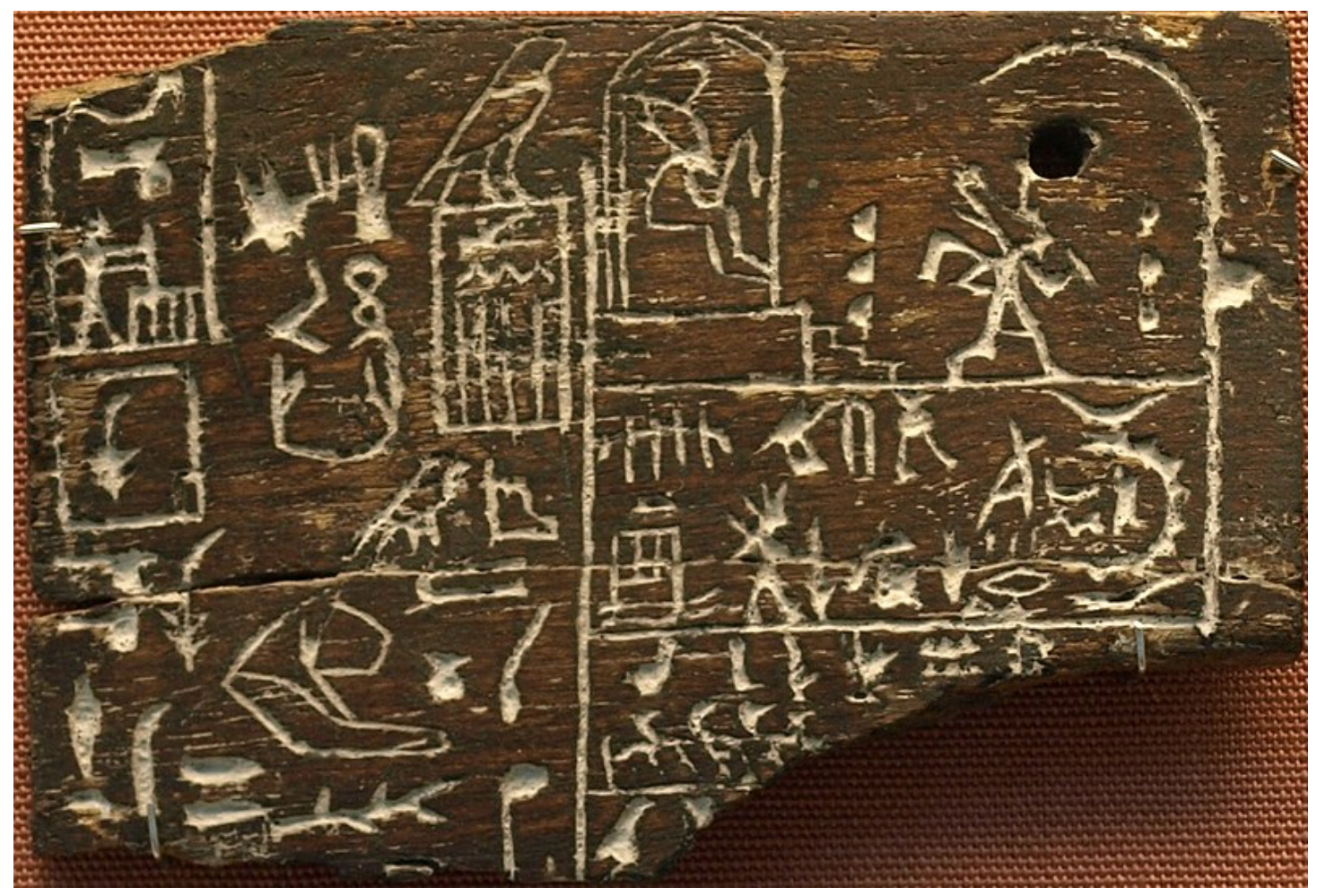

Hemaka's name and title is mentioned left of king Den's name on this year label from Den's tomb, at the Umm el-Qa'ab.

This tomb, located in the northern part of Saqqara contained many grave goods from this era, including numerous what appear to be gaming discs and a circular wooden box containing the earliest surviving piece of papyrus(W. B. Emery: Excavations at Saqqara: the tomb of Hemaka, Cairo: Government Press and Wilkinson, Toby A. H. Early Dynastic Egypt. p. 65. Routledge, 1999. ISBN 0-203-20421-2). The wealth of goods from this tomb as well as those of other officials from this time are thought to reflect the relative prosperity of Den's reign. 


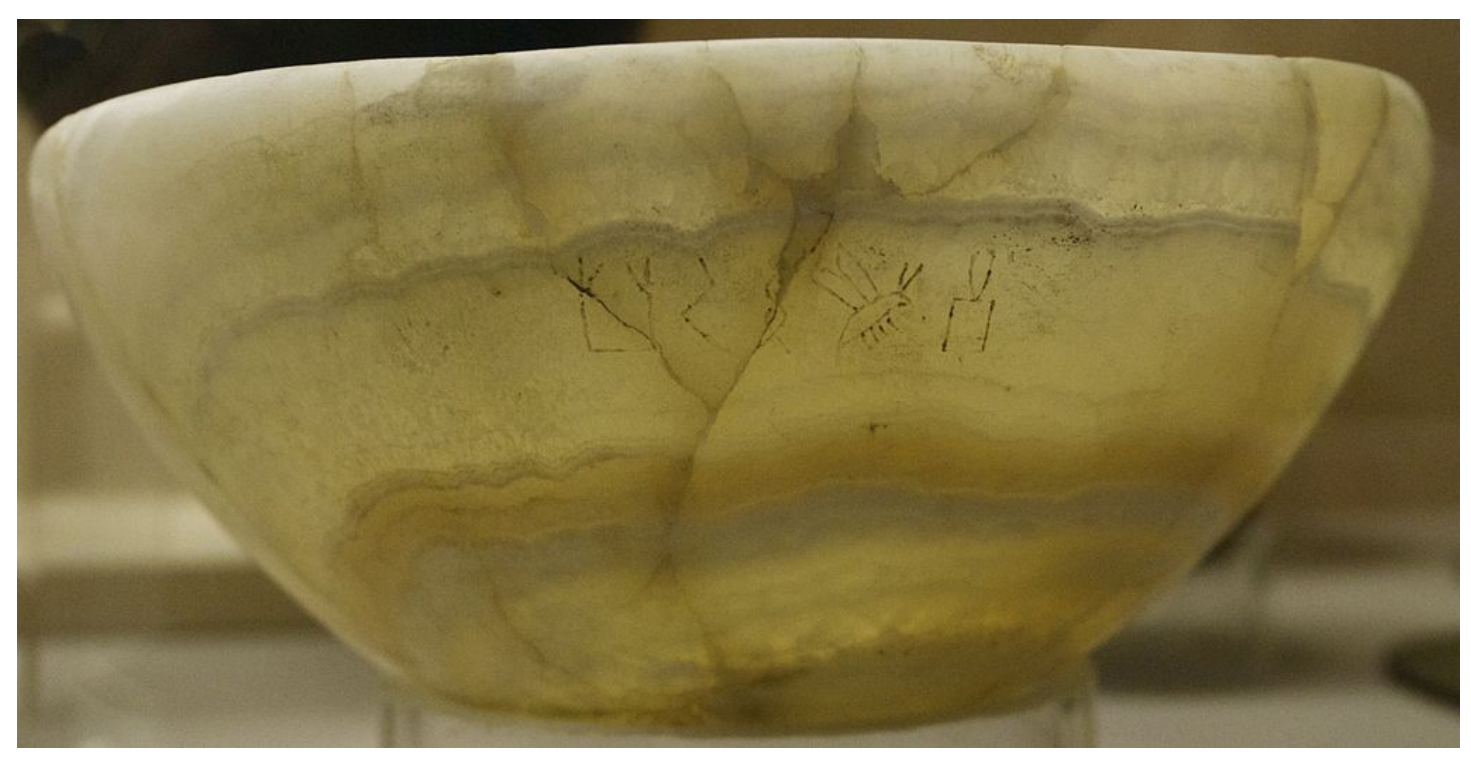

Alabaster vase bearing the name of Hemaka and his title seal-bearer of the king of Lower Egypt, National Archaeological Museum (France).

As seen from inscriptions on pottery seals, Hemaka was also responsible for maintaining one of the royal domains of king Den, a farm or vineyard for express use of the royal family and later to support the king's funerary cult(Wilkinson, Toby A. H. Early Dynastic Egypt. p. 101. Routledge, 1999. ISBN 0-203-20421-2).It seems likely that he began his service to the king in this position, succeeding to governing other domains until he rose to the position of chancellor( Wilkinson, Toby A. H. Early Dynastic Egypt. p. 124-125. Routledge, 1999. ISBN 0-203-20421-2).

Besides, the images below are the prototypes of Qi(弃) and Ji (稷): 


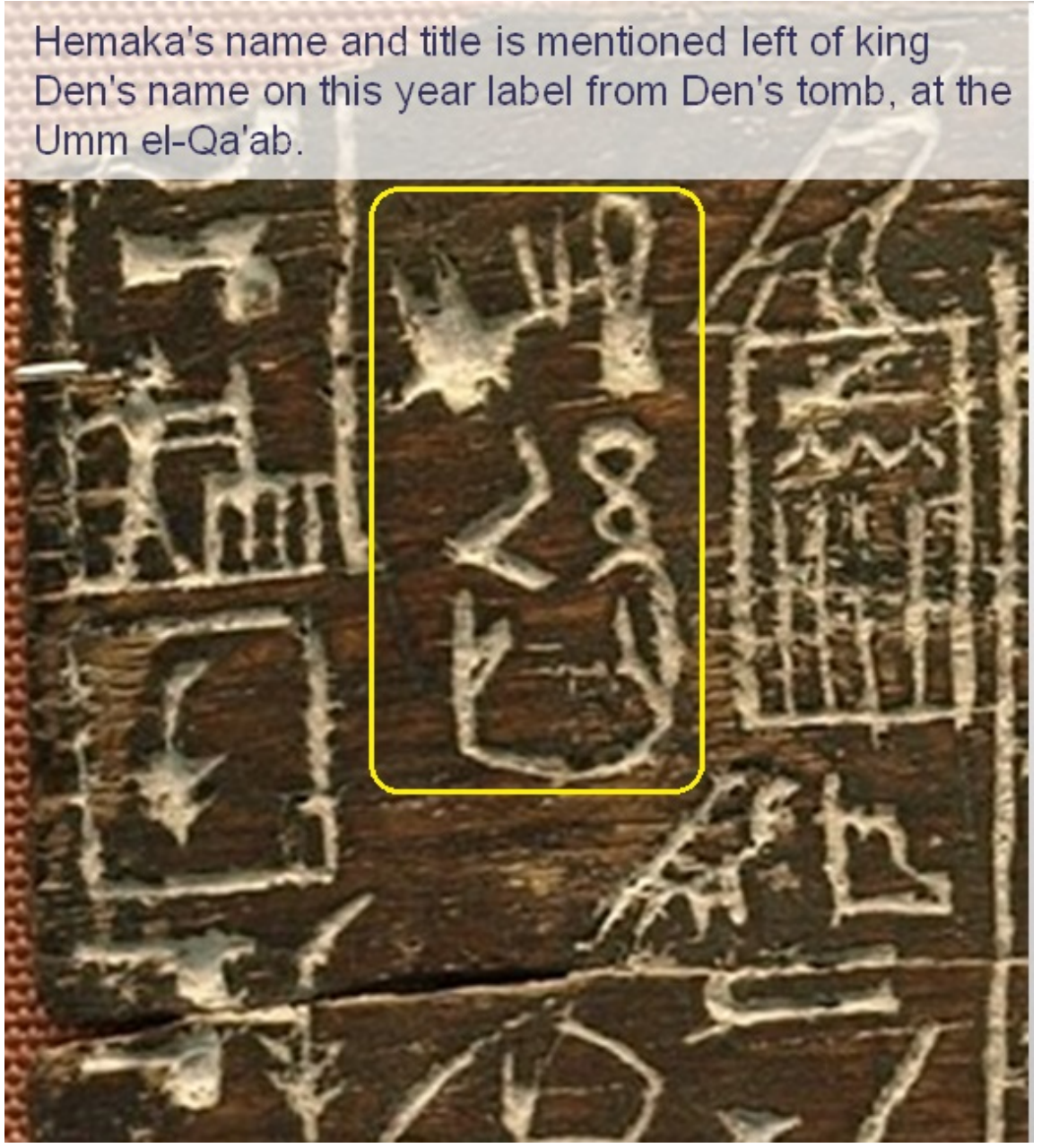




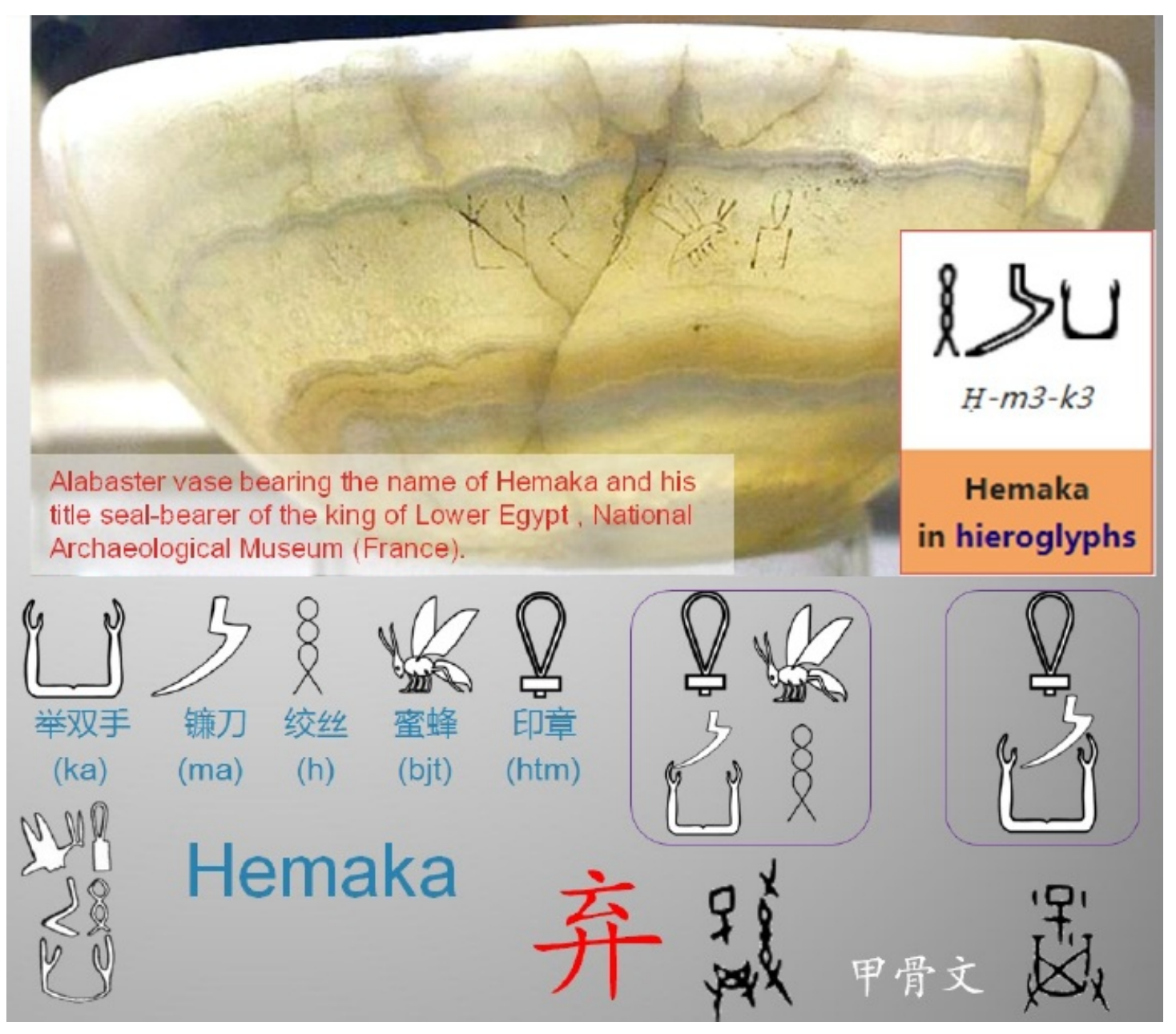




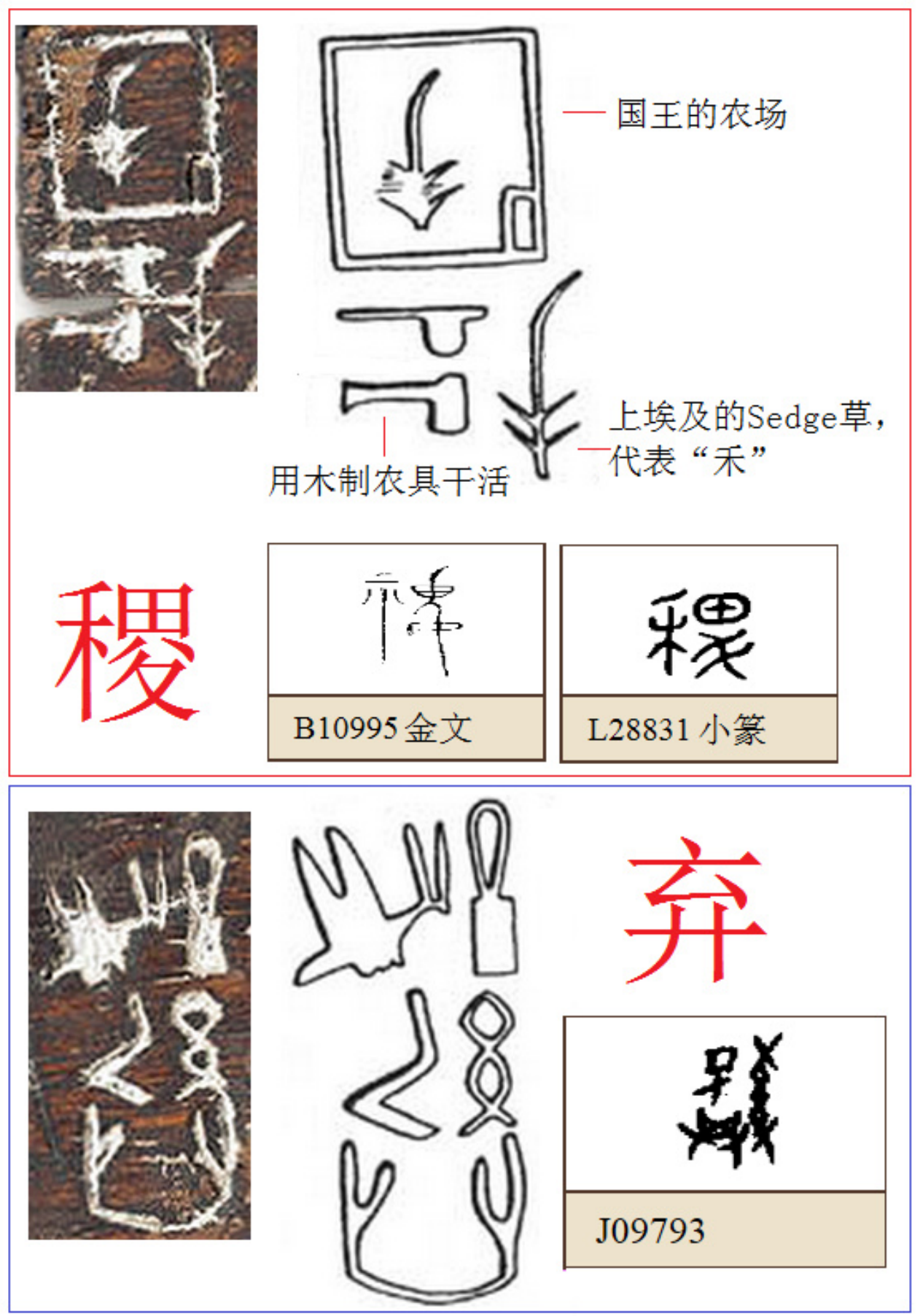



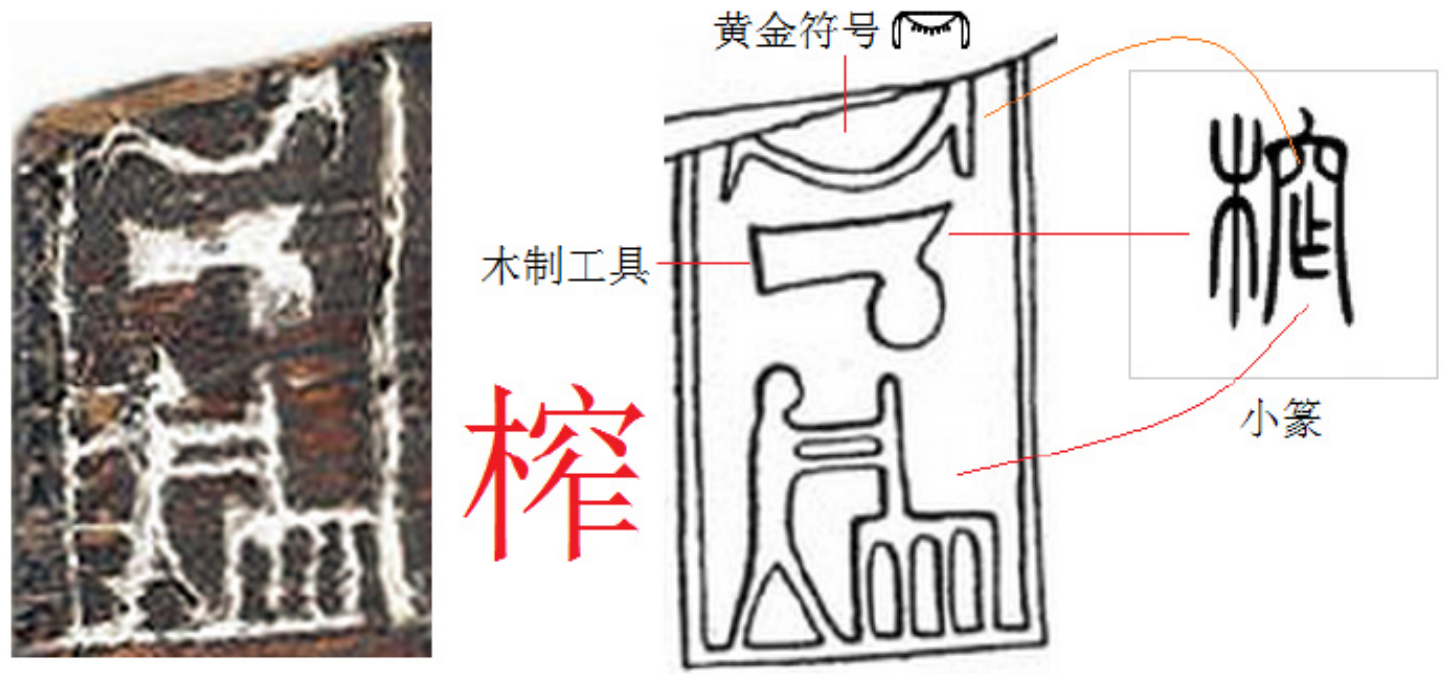

榨出金黄的油

The prototype of Zha(榨) 

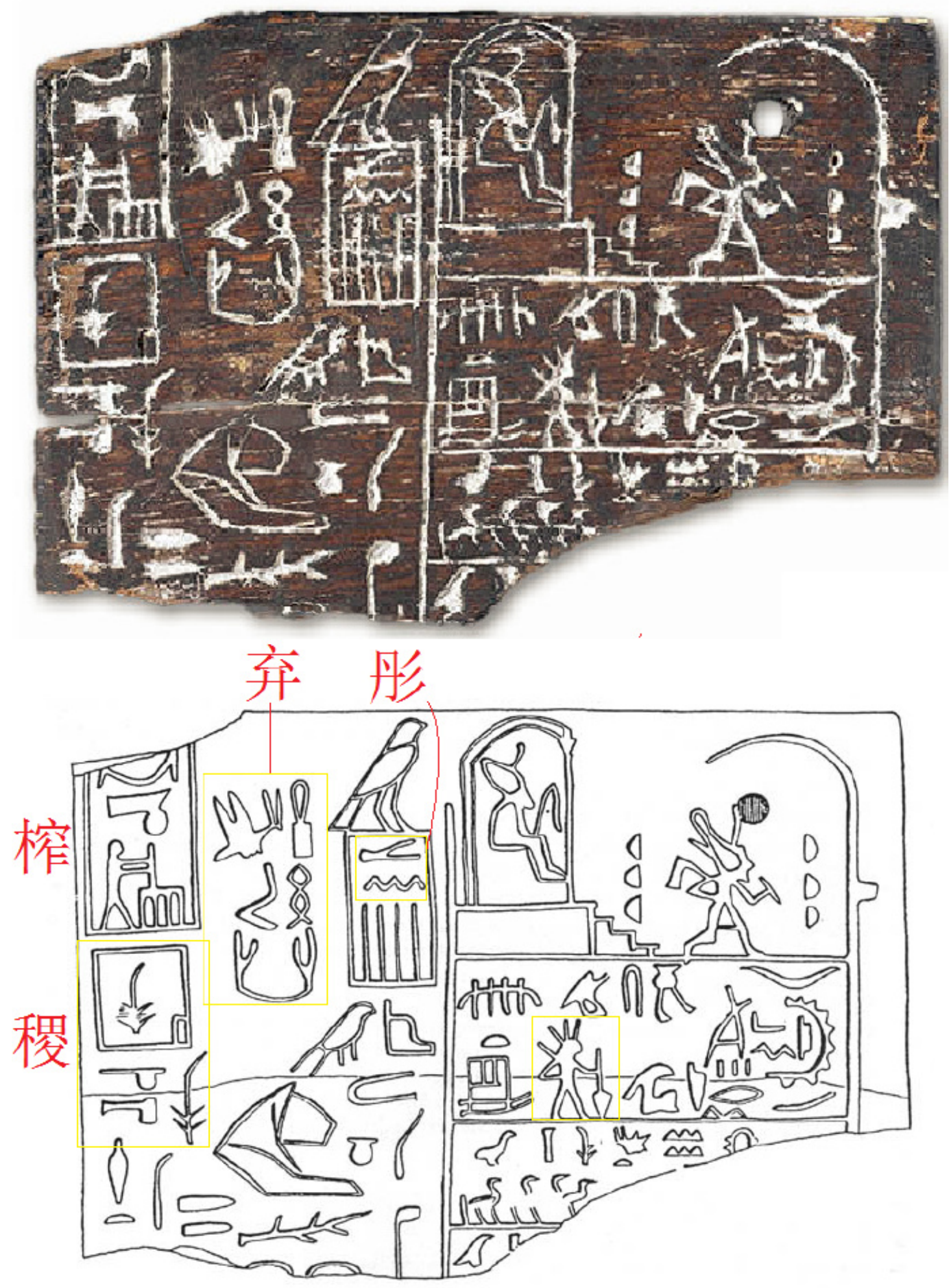

Hou Ji(后稷) extracting the oil 


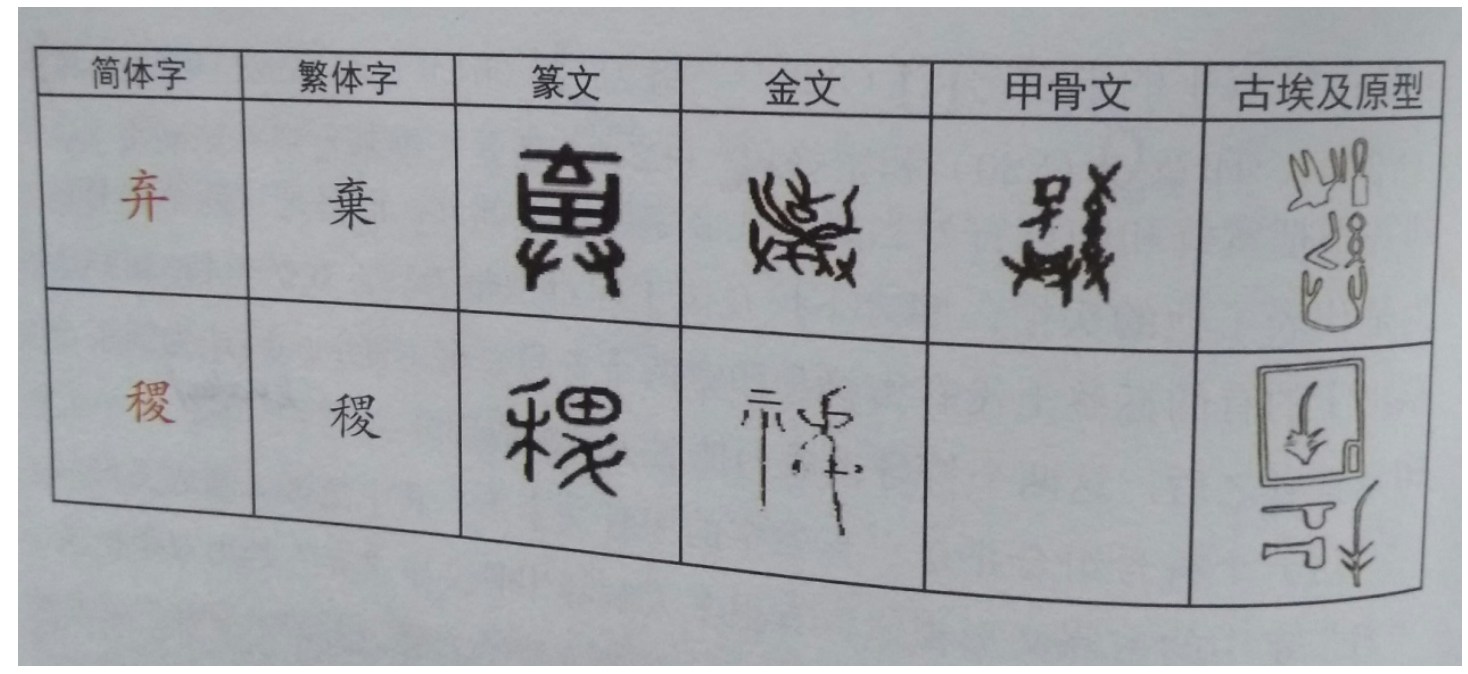

So from the above, we can get a conclusion that Qi(弃) is actually Hemaka.

The Tribe of Dan (Hebrew: ఛִ̣T), meaning, "Judge", was one of the tribes of Israel, according to the Torah. They were allocated a coastal portion of land when the people of Israel entered the Promised Land, later moving northwards.

In the Biblical census of the Book of Numbers, the tribe of Dan is portrayed as the second largest Israelite tribe (after Judah)( Numbers 1:39). Some textual scholars regard the census as being from the Priestly Source, dating it to around the 7th century $B C$, and more likely to reflect the biases of its authors(Richard Elliott Friedman, Who Wrote the Bible? (Harper San Francisco) (1987) ISBN 0-06-063035-3 and "NUMBERS, BOOK OF JewishEncyclopedia.com". www.jewishencyclopedia.com.). In the Blessing of Moses, which some textual scholars regard as dating from only slightly earlier than the deuteronomist(Richard Elliott Friedman, Who Wrote the Bible? (Harper San Francisco) (1987) ISBN 0-06-063035-3), Dan is prophesied to "leap from Bashan"; scholars are uncertain why this should be since the 
tribe did not live in the Bashan plain, east of the Jordan River("DAN JewishEncyclopedia.com". www.jewishencyclopedia.com.).

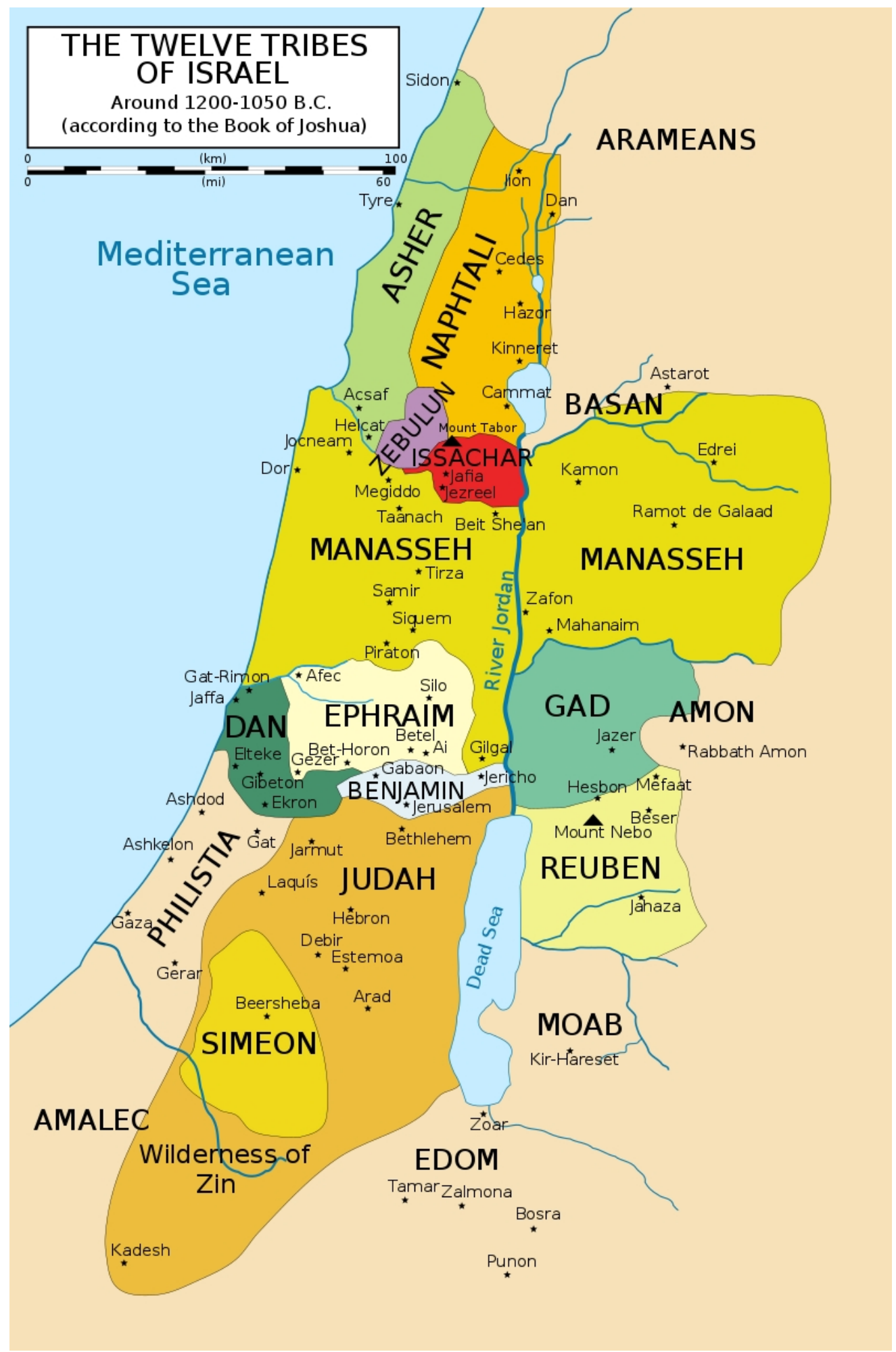

The initial territory of Dan appears in dark green north of Philistia on this map of the tribes. 
According to the biblical narrative, following the completion of the conquest of Canaan by the Israelite tribes after about 1200 BCE(Kitchen, Kenneth A. (2003)), Joshua allocated the land among the twelve tribes. Dan was the last tribe to receive its territorial inheritance. The land originally allocated to Dan was a small enclave in the central coastal area of Canaan, between Judah, Benjamin, Ephraim and the Philistines("The New American Bible - IntraText". www.vatican.va.).

From after the conquest of the land by Joshua until the formation of the first united Kingdom of Israel in c. 1050 BC, the Tribe of Dan was a part of a loose confederation of Israelite tribes. No central government existed, and in times of crisis the people were led by ad hoc leaders known as Judges(Galpaz-Feller, Pnina. Samson: the hero and the man, Peter Lang, 2006. ISBN 3-03910-852-2, ISBN 978-3-03910-852-7. p. 278-282).

With the growth of the threat from Philistine incursions, the Israelite tribes decided to form a strong centralised monarchy to meet the challenge, and the Tribe of Dan joined the new kingdom with Saul as the first king. After the death of Saul, all the tribes other than Judah remained loyal to the House of Saul. But after the death of Ish-bosheth, Saul's son and successor to the throne of Israel, the Tribe of Dan joined the other northern Israelite tribes in making David, who was then the king of Judah, king of a re-united Kingdom of Israel( Boda, Sharon La (March 23, 1994). "International Dictionary of Historic Places: Middle East and Africa". Taylor \& Francis - via Google Books.). The tribe provided substantial military support for the kingdom in the form of 28,600 soldiers, being considered "experts in war"("1 Chronicles 12:35", King James Bible Online. Retrieved 15 may 2018). 


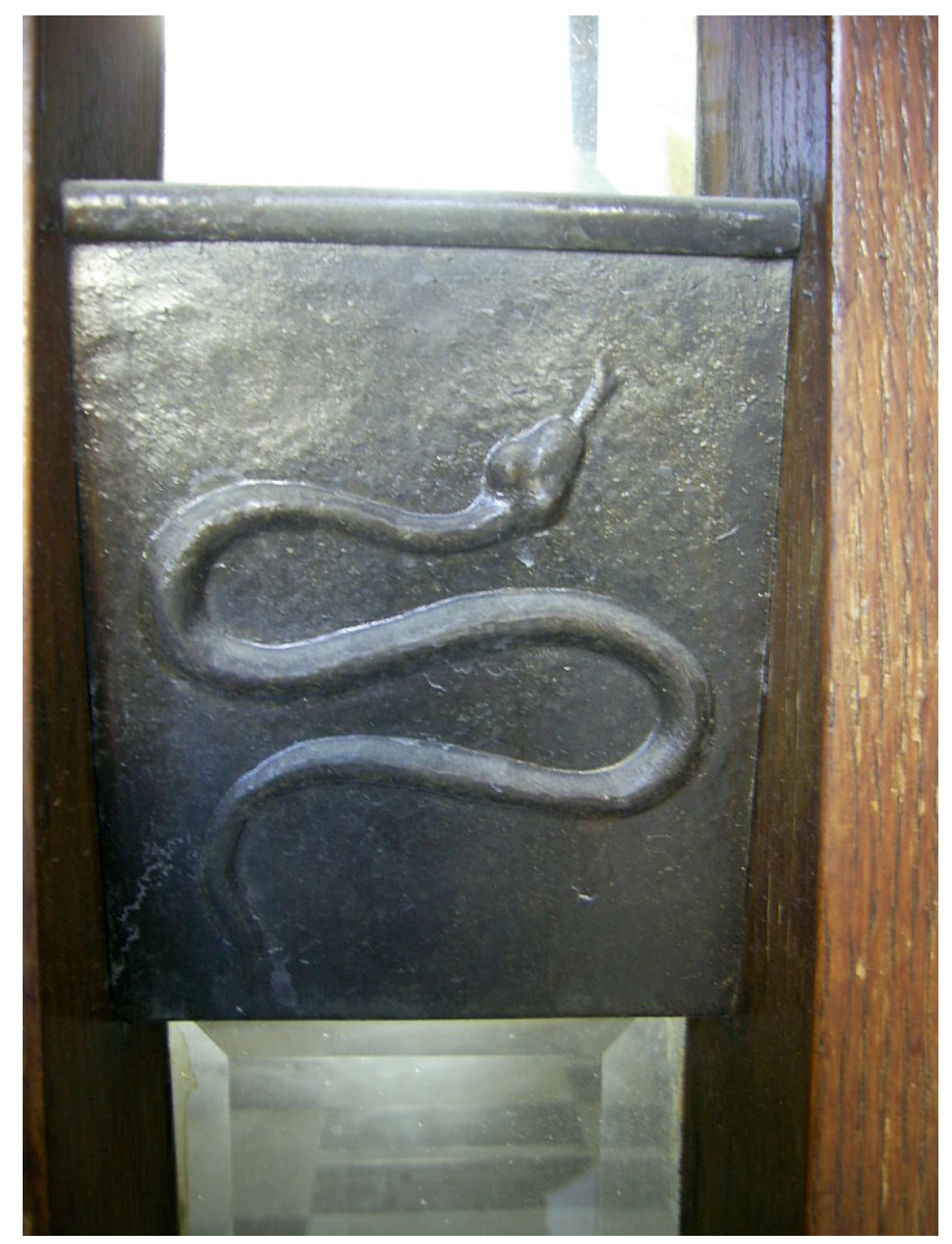

The Dan tribe's serpent plate on the Heichal Shlomo's door in Jerusalem.

Modern artists use the "scales of justice" to represent the Tribe of Dan due to Genesis 49:16 referencing Dan "shall achieve justice for his kindred". More traditional artists use a snake to represent Dan(like Wadjet of ancient Egypt), based upon Genesis 49:17, "Let Dan be a serpent by the roadside, a horned viper by the path, that bites the horse's heel, so that the rider tumbles backward." 


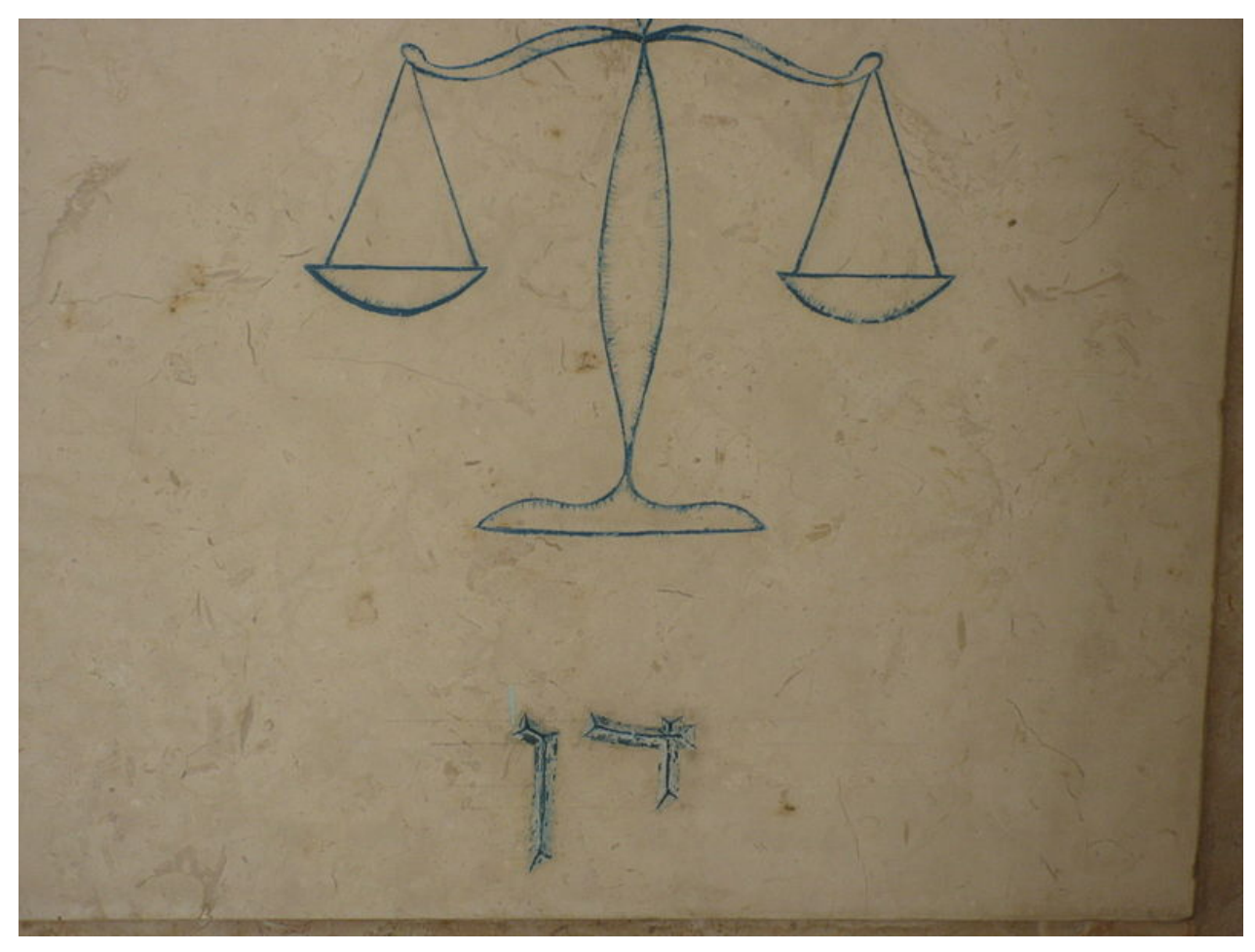

The scales of justice emblem of the tribe of Dan.

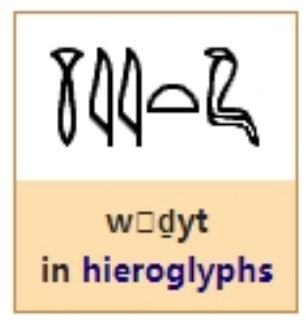

Wadjet in Hieroglyphs 


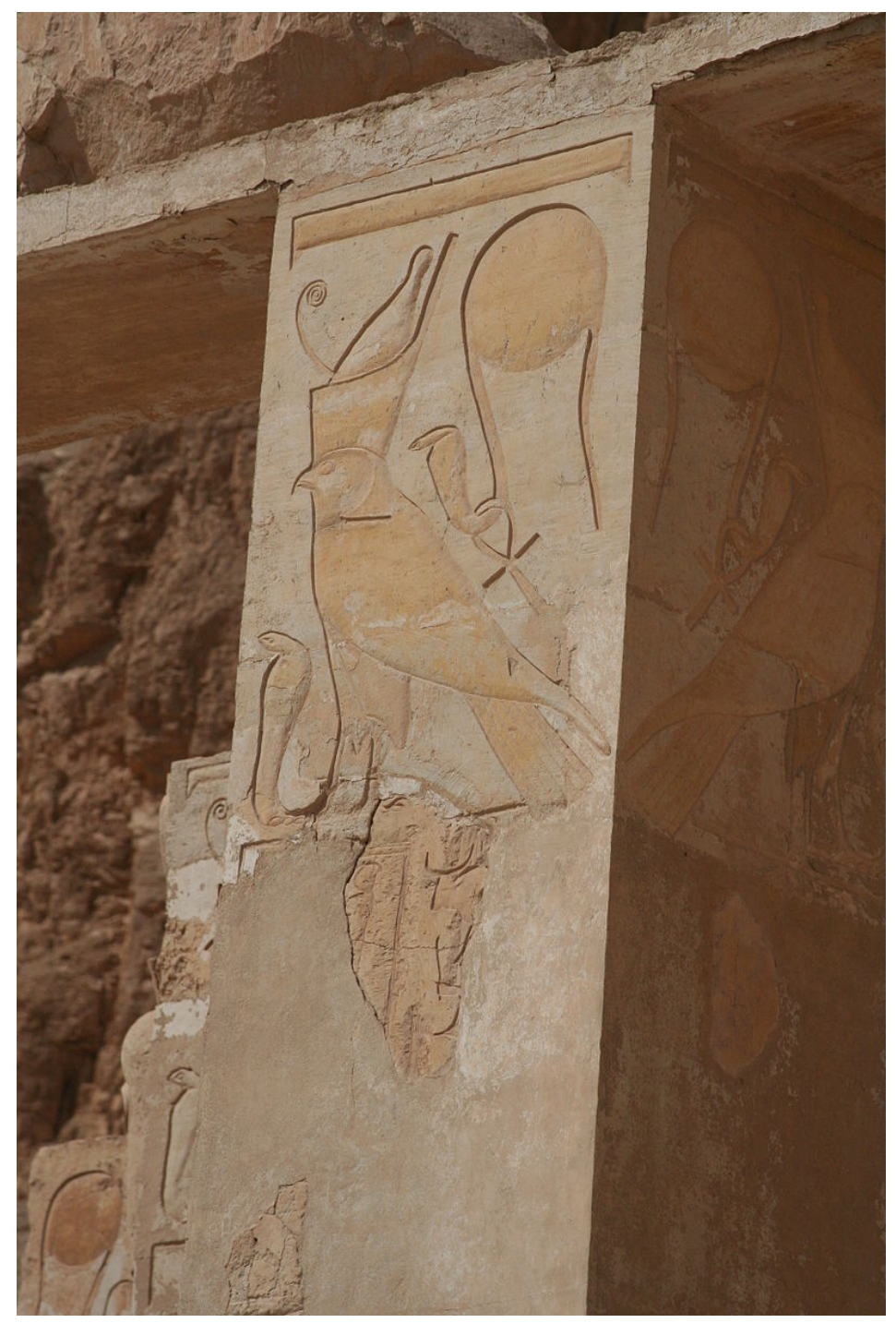

Two images of Wadjet appear on this carved wall in the Hatshepsut Temple at Luxor.

The Merneptah Stele - also known as the Israel Stele or the Victory Stele of Merneptah - is an inscription by the ancient Egyptian Pharaoh Merneptah (reign: 1213-1203 BCE) discovered by Flinders Petrie in 1896 at Thebes, and now housed in the Egyptian Museum in Cairo(Drower 1985, p. 221 and Redmount 2001, pp. 71-72, 97 ).

The text is largely an account of Merneptah's victory over the Libyans and their allies, but the last 3 of the 28 lines deal with a separate campaign in Canaan, then part of Egypt's imperial possessions. The stele is sometimes referred to as the "Israel Stela" because a majority of 
scholars translate a set of hieroglyphs in line 27 as "Israel". Alternative translations have been advanced but are not widely accepted(Kenton L. Sparks (1998).).

The stela represents the earliest textual reference to Israel and the only reference from ancient Egypt( Hasel 1998, p. 194).

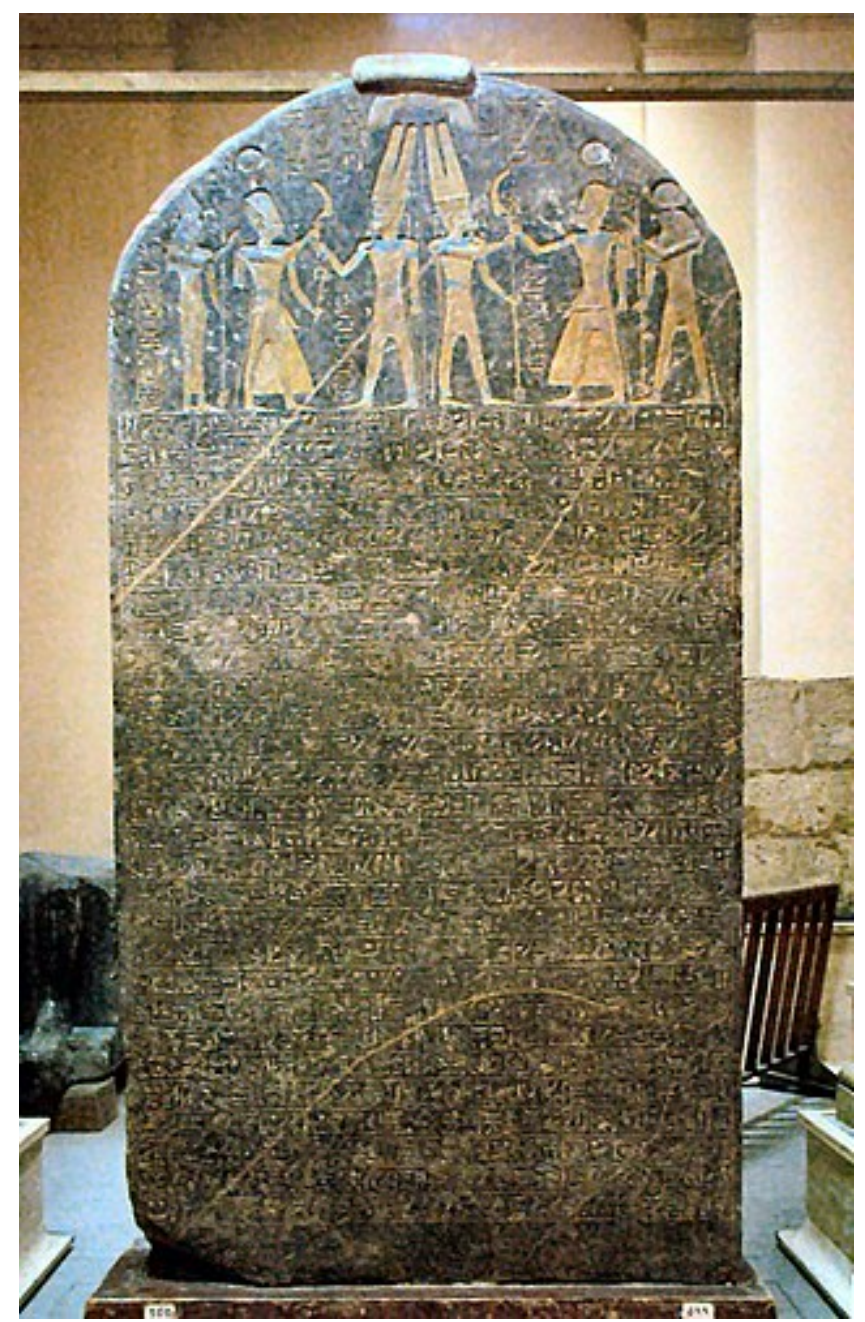

The Merneptah Stele in its current location 


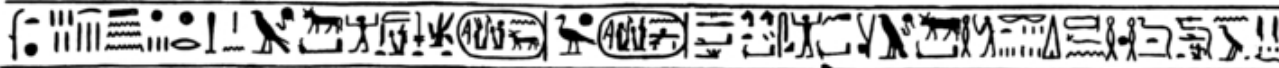

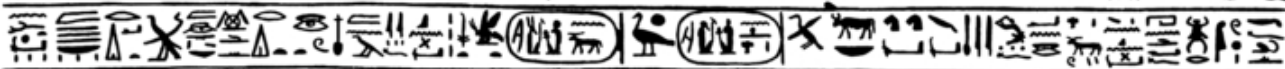

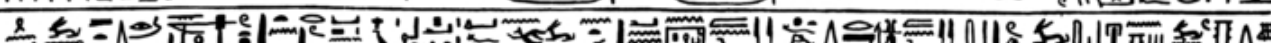

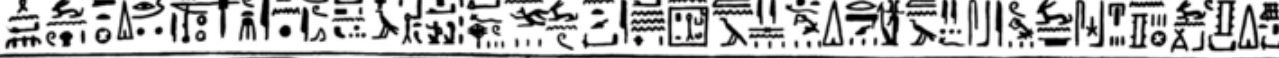

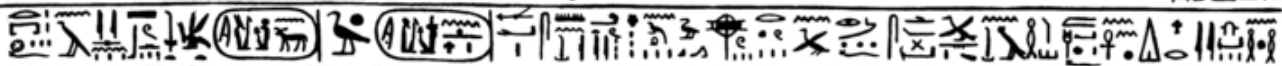

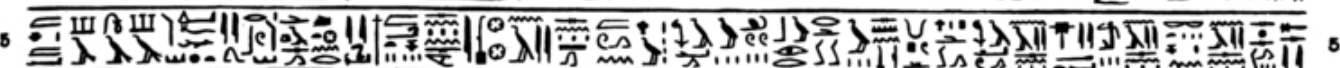

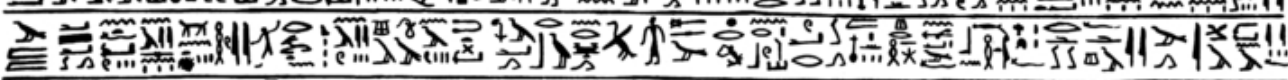

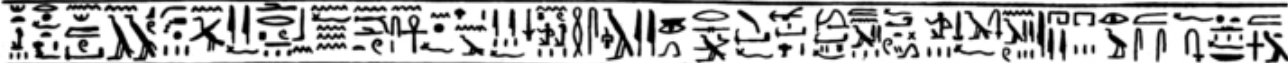

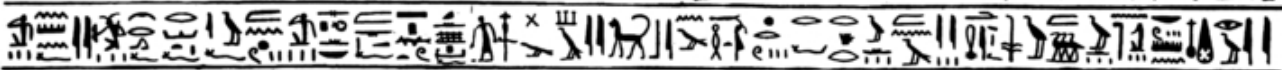

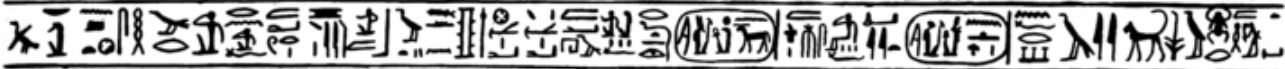

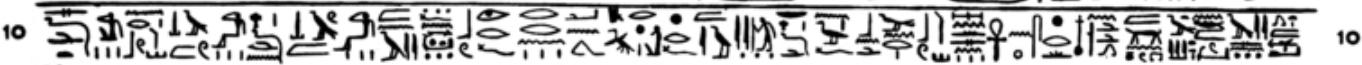

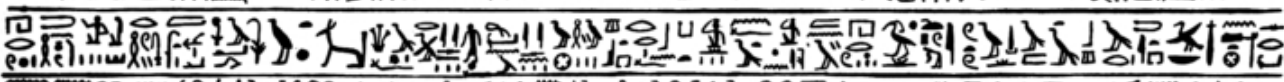
:

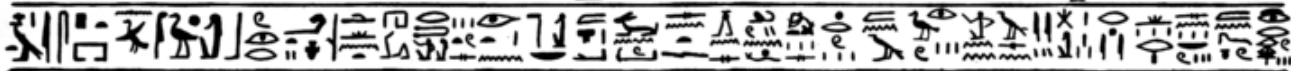

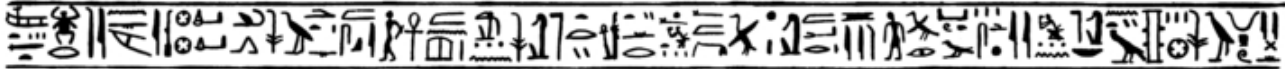

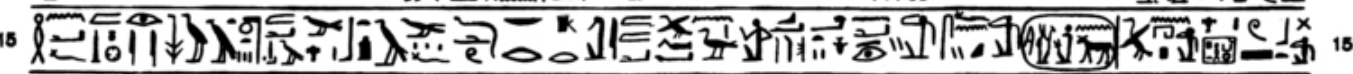

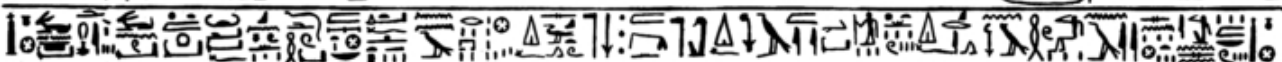

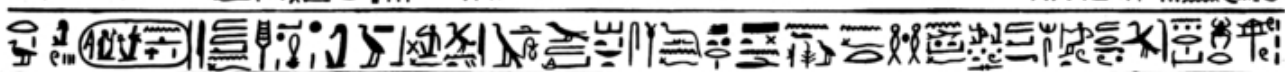

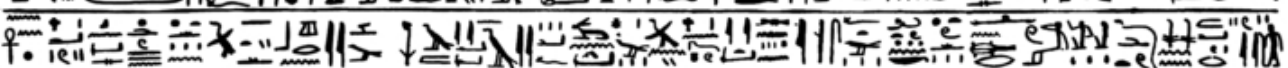

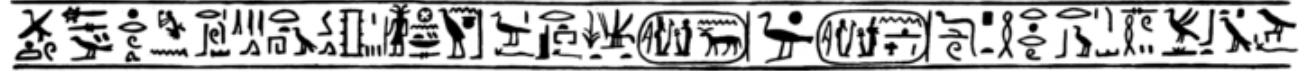

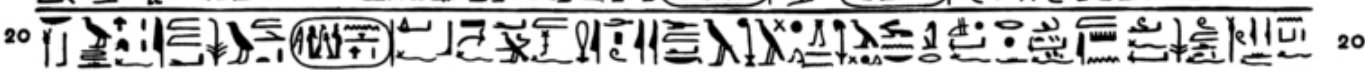

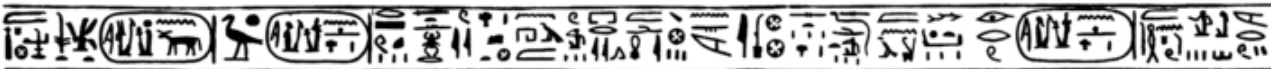

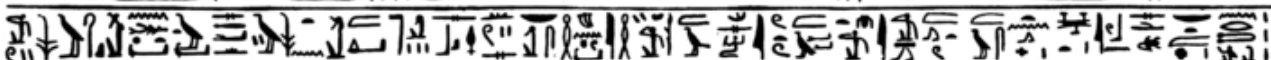

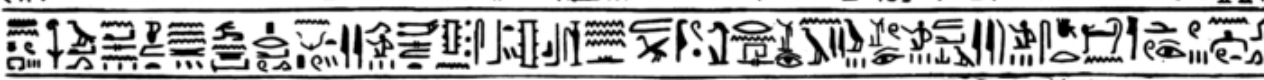

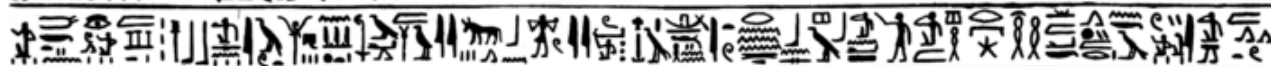

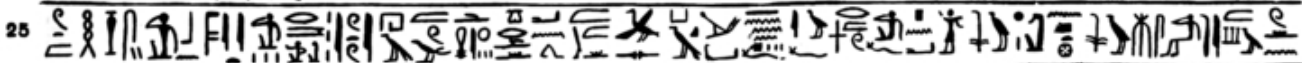

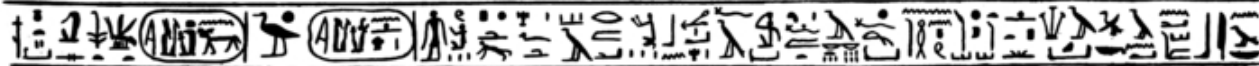

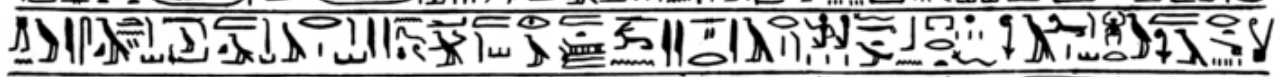
F1:0

Flinders Petrie's 1897 mirror image copy of the main part of the inscription (all 28 lines)

The line which refers to Israel is: 


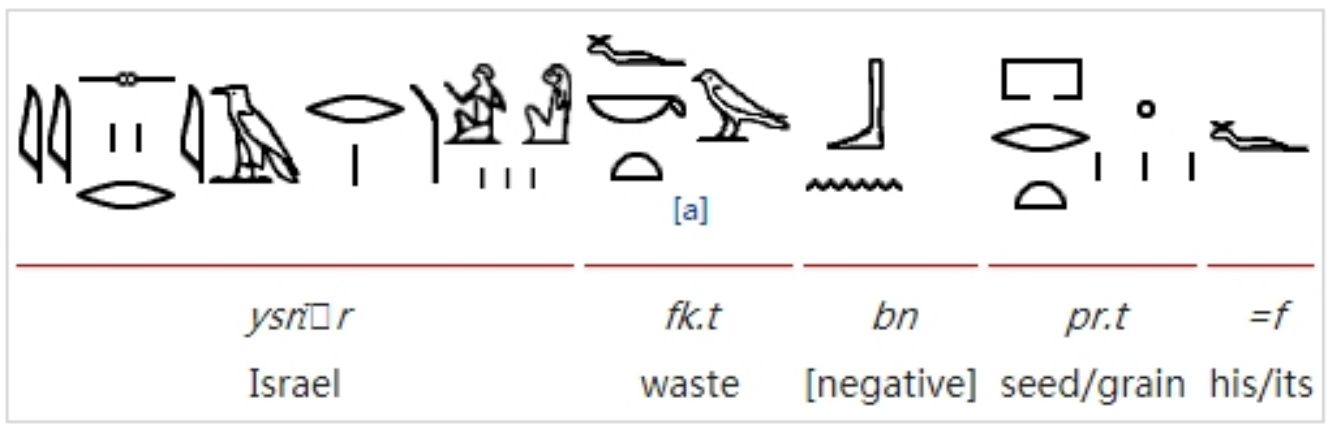

While Ashkelon, Gezer and Yanoam are given the determinative for a city - a throw stick plus three mountains - the hieroglyphs that refer to Israel instead employ the throw stick (the determinative for "foreign") plus a sitting man and woman (the determinative for "people") over three vertical lines (a plural marker):

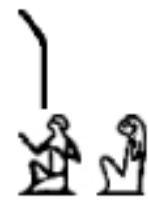

I I I

According to The Oxford History of the biblical World, this "foreign people" "sign is typically used by the Egyptians to signify nomadic groups or peoples, without a fixed city-state home, thus implying a seminomadic or rural status for 'Israel' at that time(Redmount 2001, p. 97.)." The phrase "wasted, bare of seed" is formulaic, and often used of defeated nations - it implies that the grain-store of the nation in question has been destroyed, which would result in a famine the following year, incapacitating them as a military threat to Egypt(Redmount 2001, p. 97.).

The Doctrine of the Mean or Zhongyong is both a doctrine of Confucianism and also the title of one of the Four Books of Confucian philosophy. The text is attributed to Zisi or Kong Ji, 
the only grandson of Confucius. It was published as a chapter in the Classic of Rites.

The phrase "doctrine of the mean" first occurs in Book VI, verse 29 of the Analects of Confucius:

The Master [Confucius] said, The virtue embodied in the doctrine of the Mean is of the highest order. But it has long been rare among people

- Analects, 6:29 (Burton Watson tr.)

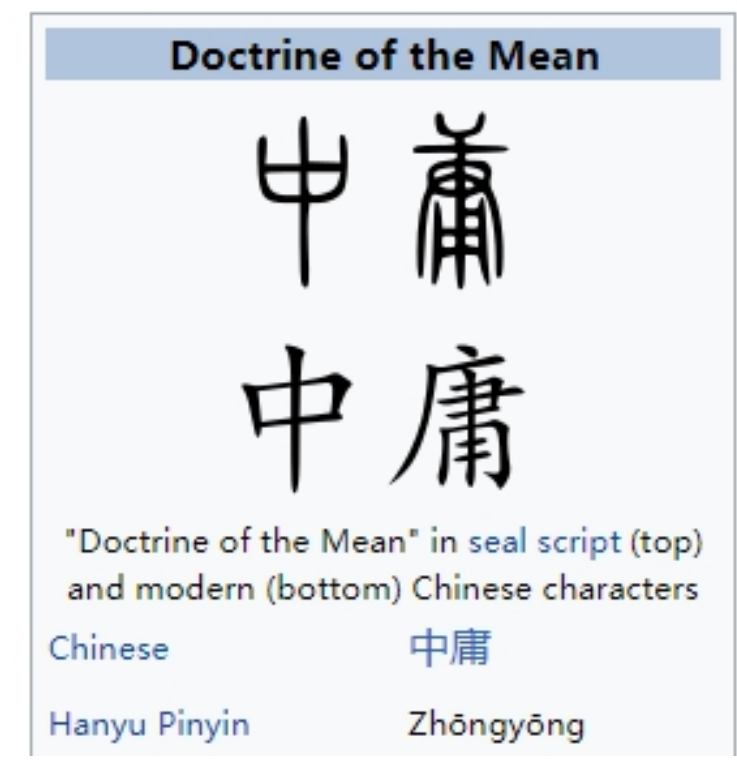

The Doctrine of the Mean is a text rich with symbolism and guidance to perfecting oneself. The mean is also described as the ["unswerving pivot" = Ezra Pound] 'unwobbling pivot' or zhongyong. Zhong means bent neither one way or another, and yong represents unchanging(The Great Digest and Unwobbling Pivot, 1951.). In James Legge's translation of the text, the goal of the mean is to maintain balance and harmony from directing the mind to a state of constant equilibrium. The person who follows the mean is on a path of duty and must never leave it. A superior person is cautious, a gentle teacher and shows no contempt for his or her inferiors. S/he always does what is natural according to her or his status in the world. Even common men and women can carry the mean 
into their practices, as long as they do not exceed their natural order(Internet Sacred Text Archive, 2008.).

The Doctrine of the Mean represents moderation, rectitude, objectivity, sincerity, honesty and propriety(Encyclopædia Britannica (2008). Britannica Encyclopedia. Rosen Pub Group. ISBN 1-59339-292-3.). The guiding principle is that one should never act in excess.

So from the above, we can say that the origin of the doctrine of the mean may be the scales of justice emblem of the tribe of Dan.

Haplogroup Q or Q-M242 is a Y-chromosome DNA haplogroup. It has one primary subclade, Haplogroup Q1(L232/S432), which includes numerous subclades that have been sampled and identified in males among modern populations.

Q-M242 is the predominant Y-DNA haplogroup among Native Americans and several peoples of Central Asia and Northern Siberia. It is also the predominant Y-DNA of the Akha tribe in northern Thailand and the Dayak people of Indonesia.

Haplogroup Q-M242 is one of the two branches of P1-M45 also known as K2b2a (The other is R-M207).

Q-M242 is believed to have arisen around the Altai Mountains area (or South Central Siberia)( Zegura, S. L.; Karafet, TM; Zhivotovsky, LA; Hammer, MF (2004).), approximately 17,000 to 31,700 years ago( YFull YTree v4.02). However, the matter remains unclear due to limited sample sizes and changing definitions of Haplogroup Q: early definitions used a combination of the SNPs M242, P36.2, and MEH2 as defining mutations. 
The subclades of Haplogroup Q-M242 with their defining mutation (s), according to the 2015 ISOGG tree(Y-DNA Haplogroup $Q$ and its Subclades 2016) are provided below. The first three levels of subclades are shown. Additional detail is provided on the linked branch article pages.

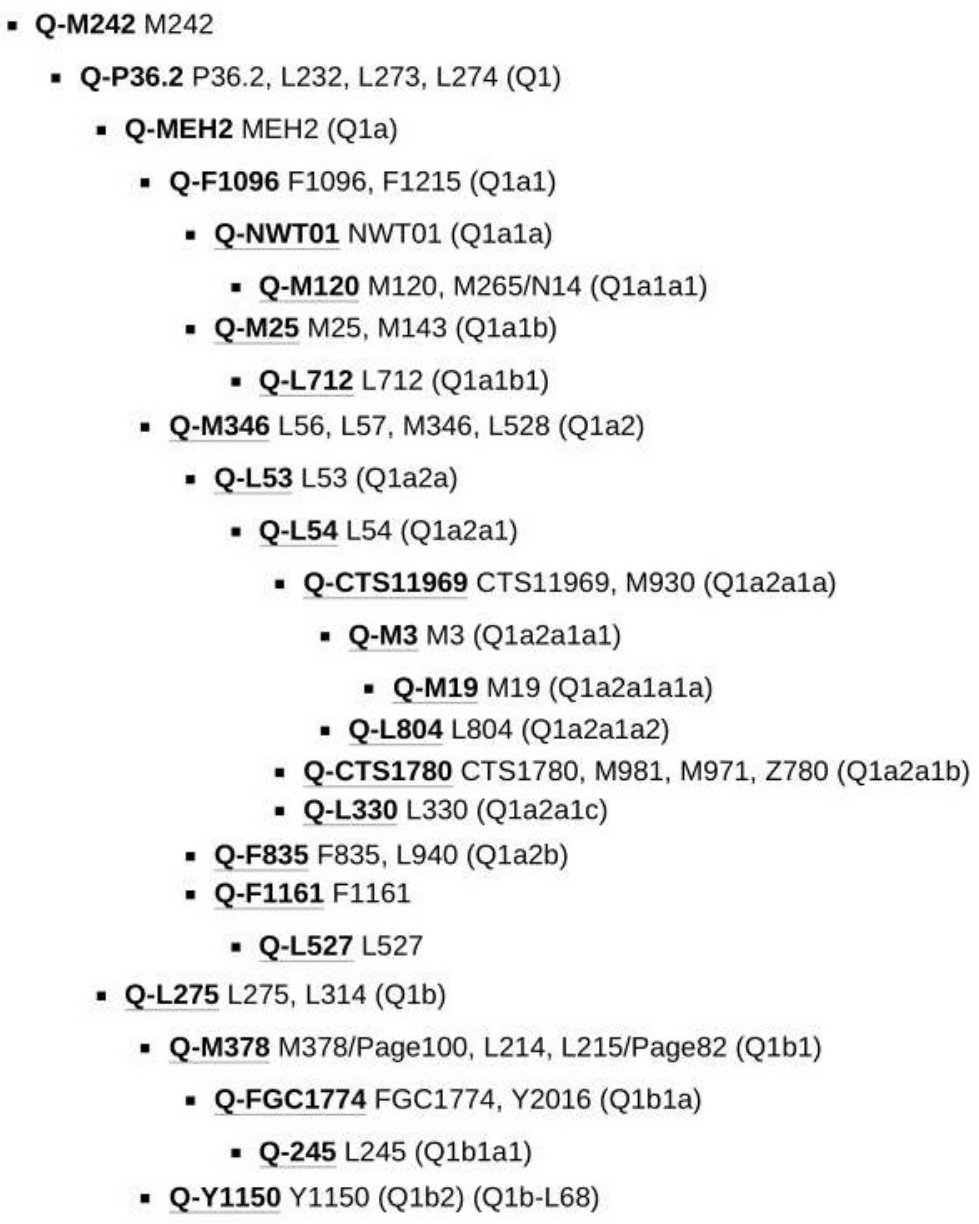




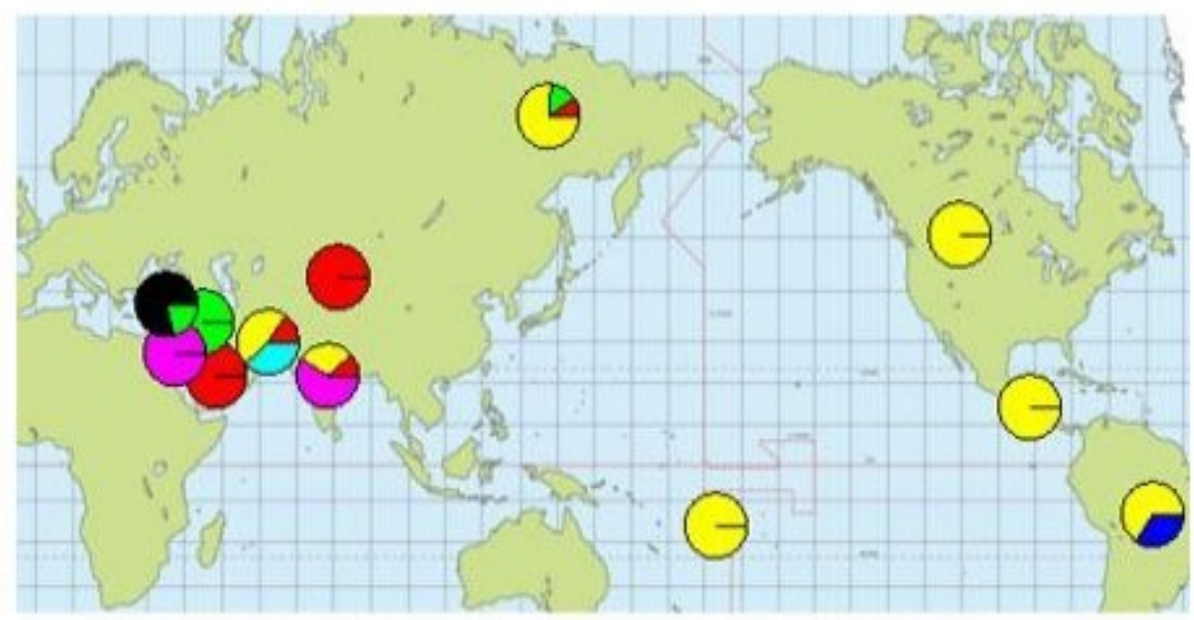

Q1a*

Q1a1

Q1a2

Q1a3 or Q1a3a

Q1a3a1

Q1 a6

Q1b

Figure 6. Relative frequency distribution of the subclades of Haplogroup Q.

The pie charts indicate the relative contribution of the different subclades in geographical areas where Haplogroup $Q$ has been detected. Clearly, Subclade Q1a3a is widely distributed throughout the Americas with Q1a3a1 also detected in South America. The yellow pies in Pakistan and India likely represent Subclade Q1a3*, and not the Native American Subclade Q1a3a. 


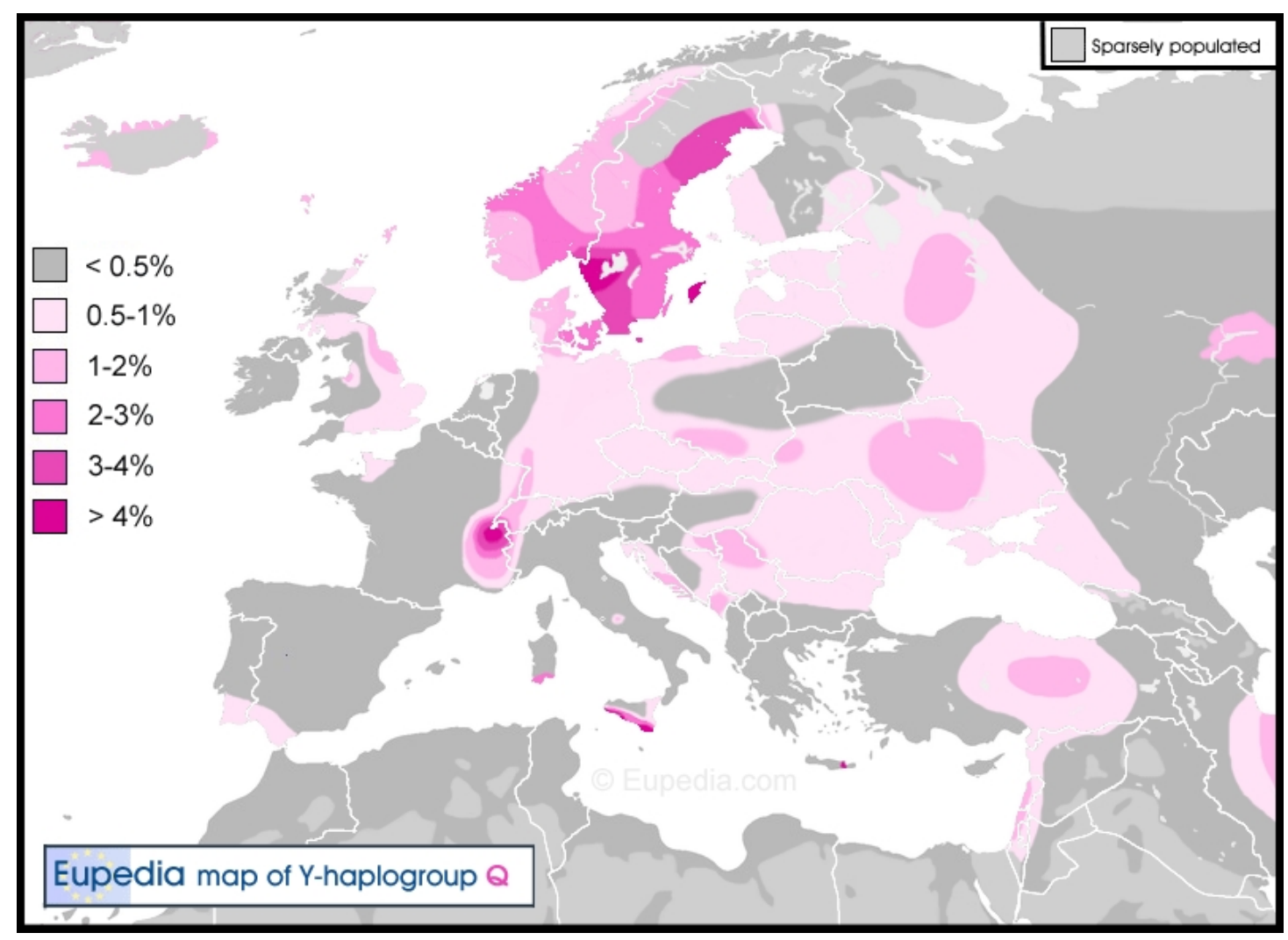

Distribution of haplogroup Q in Europe

Phylogenetic tree of Haplogroup Q1a

(as of February 2017)

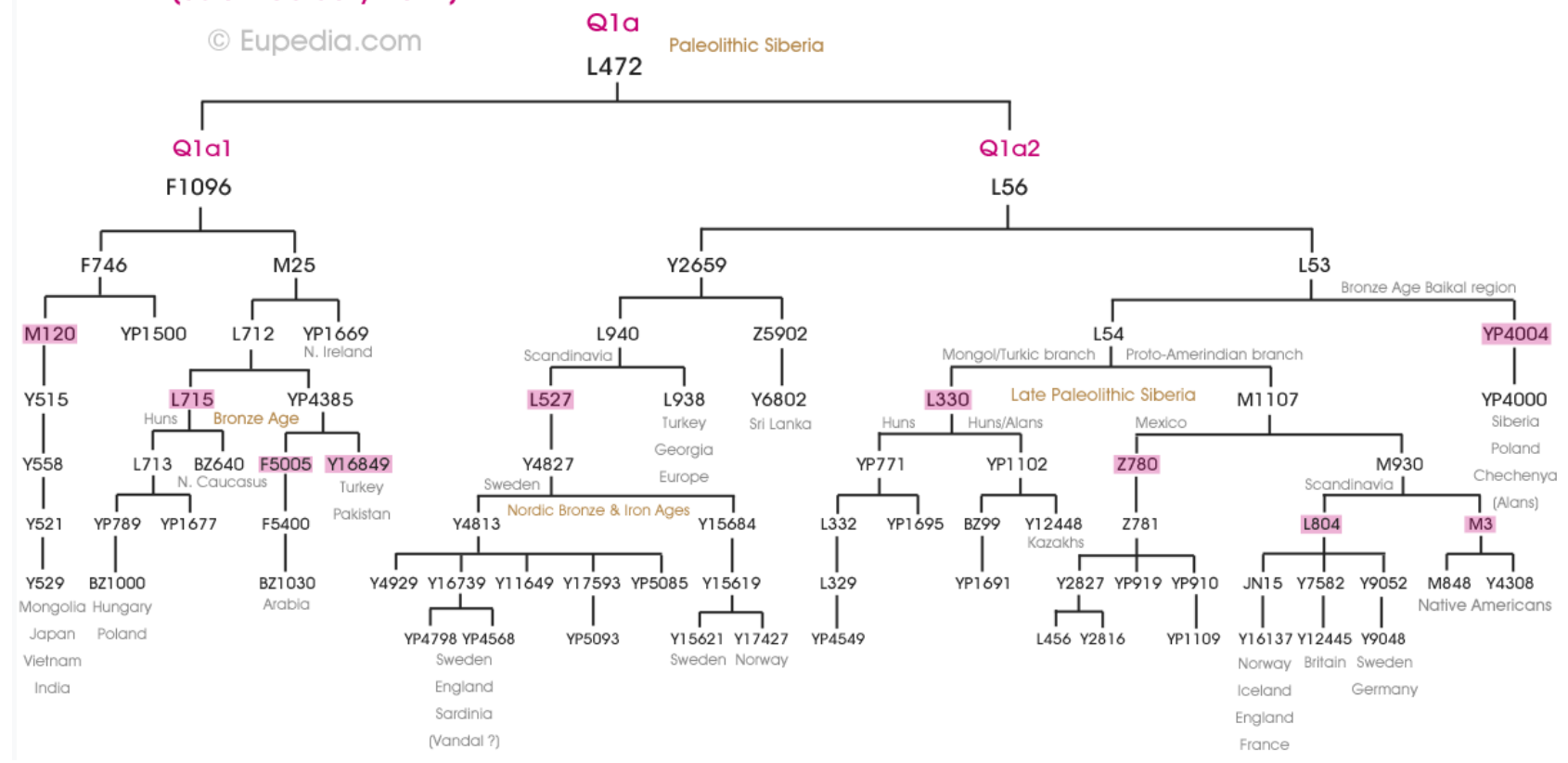


Phylogenetic tree of Haplogroup Q

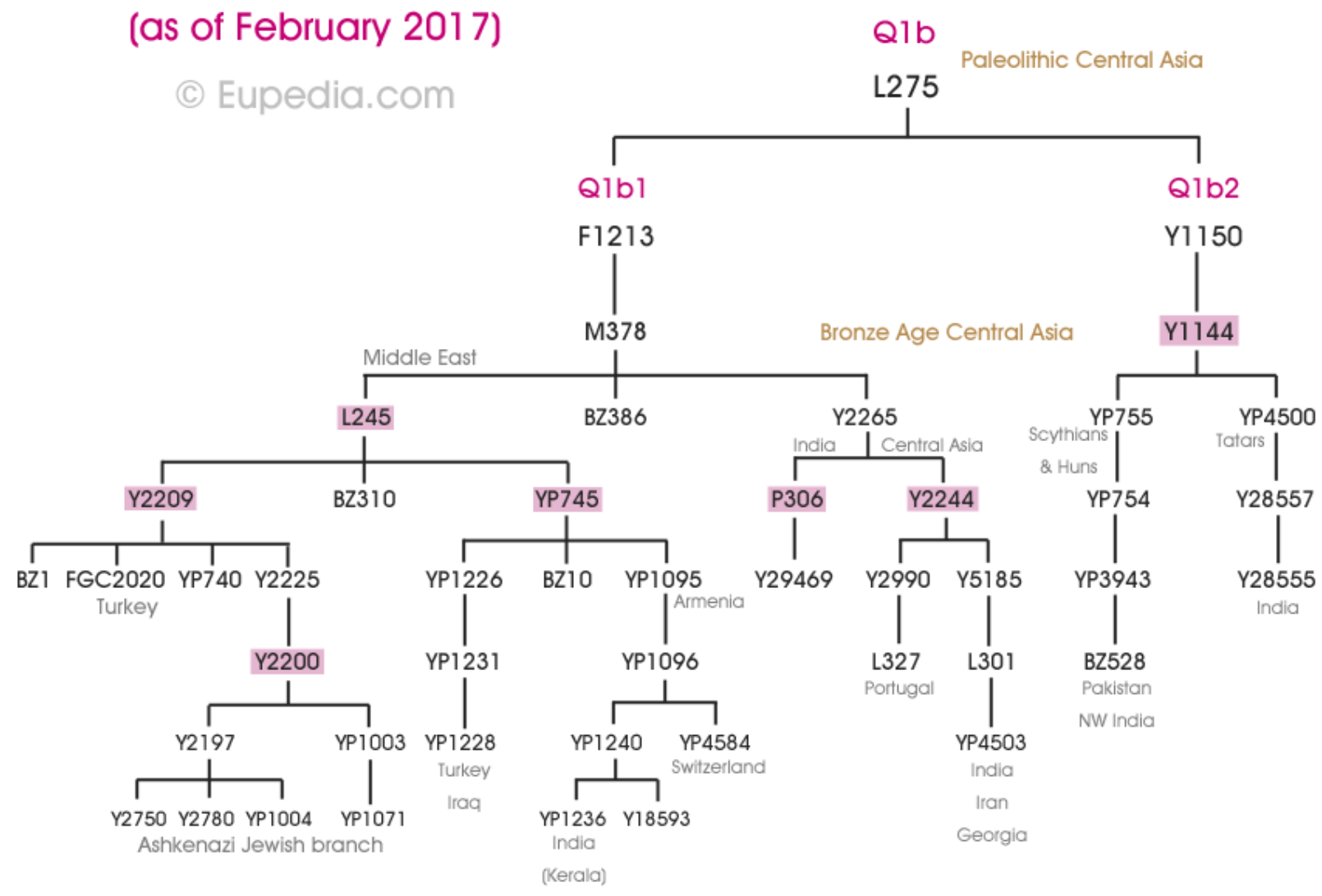

However, most of Q-M242 people in East Asia belong to subclade QM120, which distributes most intensively across northern China (the provinces of which the capitals locate northern to Huai River-Qin Mountains line). Q-M242 ranged from $4 \sim 8 \%$ in northwest China (Xinjiang, Gansu, Shaanxi), north China (Shanxi, Hebei), central China (Henan), and upper east China (Shandong) to $3 \sim 4 \%$ in northeast China. The average frequency of Q-M242 in northern China is around $4.5 \%$. However, it decreases to about $2 \%$ in southern China(Wen B, Li H, Lu D, et al. (September 2004) and Su, Bing; Xiao, Chunjie; Deka, Ranjan; Seielstad, Mark T.; Kangwanpong, Daoroong; Xiao, Junhua; Lu, Daru; Underhill, Peter; et al. (2000)). In a study published in 2011, researchers have found Q-M242 in 3.3\% $(12 / 361)$ of the samples of unrelated Han-Chinese male volunteers at Fudan University in Shanghai with the origins from all over China, though 
with the majority coming from east China(Yan, Shi; Chuan-; Wang, Chao; Li, Hui; et al. (2011)). In another study published in 2011, Hua Zhong et al. found haplogroup Q-M242 in 3.99\% (34/853, including 30/853 QM120, 3/853 Q-M346, and 1/853 Q-M25) of a pool of samples of Han Chinese from northern China and 1.71\% (15/876, including 14/876 QM120 and 1/876 Q-M346) of a pool of samples of Han Chinese from southern China(Zhong, Hua; Shi, Hong; Qi, Xue-Bin; Duan, Zi-Yuan; Tan, Ping-Ping; Jin, Li; Su, Bing; Ma, Runlin Z. (2011)).

\begin{tabular}{|c|c|c|c|c|}
\hline Population & Paper & $\mathrm{N}$ & Percentage & SNP Tested \\
\hline Dungan (Kyrgyzstan) & Wells $2001^{[5]}$ & $3 / 40$ & $\sim 7.5 \%$ & M120 \\
\hline Han (Henan) & Su $2000^{[4]}$ & $2 / 28$ & $\sim 7.1 \%$ & M120 \\
\hline Han (Anhui) & Su $2000^{[4]}$ & $1 / 22$ & $\sim 4.6 \%$ & M120 \\
\hline Northern Han & Su $2000^{[4]}$ & $1 / 22$ & $\sim 4.5 \%$ & M120 \\
\hline $\begin{array}{l}\text { Kinh } \\
\text { (Ho Chi Minh City) }\end{array}$ & Poznik 2016[2] & $2 / 46$ & $\sim 4.3 \%$ & M120 \\
\hline Han (Shanghai) & Su $2000^{[4]}$ & $1 / 30$ & $\sim 3.3 \%$ & M120 \\
\hline Han (Shandong) & Su $2000^{[4]}$ & $1 / 32$ & $\sim 3.1 \%$ & M120 \\
\hline Korea & Wells $2001^{[5]}$ & $1 / 45$ & $\sim 2.2 \%$ & M120 \\
\hline Tibetan-Lhasa & Su $2000^{[4]}$ & $1 / 46$ & $\sim 2.2 \%$ & M120 \\
\hline Tibet & Gayden $2007^{[11]}$ & $2 / 156$ & $\sim 1.3 \%$ & M120 \\
\hline Han (Shanxi) & Zhong 2010[13] & $1 / 56$ & $\sim 1.8 \%$ & M120 \\
\hline Uygur (Xinjiang) & Zhong 2010[13] & $1 / 71$ & $\sim 1.4 \%$ & M120 \\
\hline Uygur (Xinjiang) & Zhong 2010[13] & $1 / 50$ & $\sim 2.0 \%$ & M120 \\
\hline Han (Jiangsu) & Su $2000^{[4]}$ & $1 / 55$ & $\sim 1.8 \%$ & M120 \\
\hline Mongolia & Di Cristofaro $2013^{[10]}$ & $2 / 160$ & $\sim 1.25 \%$ & M120 \\
\hline Japan & Nonaka $2007^{[7]}$ & $1 / 263$ & $\sim 0.38 \%$ & M120 \\
\hline
\end{tabular}

By the way, the text below is the abstract of Phylogeography of $Y$ chromosome haplogroup Q1a1a-M120, a paternal lineage connecting populations in Siberia and East Asia: 
Background: Previous studies have suggested that the human Y-chromosome haplogroup Q1a1a-M120, a widespread paternal lineage in East Asian populations, originated in South Siberia. However, much uncertainty remains regarding the origin, diversification, and expansion of this paternal lineage. Aim: To explore the origin and diffusion of paternal Q-M120 lineages in East Asia Subjects and methods: We generated 26 new Y chromosome sequences of Q-M120 males and co-analysed 45 Y chromosome sequences of this haplogroup. We reconstructed a highly revised phylogenetic tree of haplogroup Q-M120 with age estimates. Additionally, we performed a comprehensive phylogeographic analysis of this lineage including 15,007 samples from 440 populations in eastern Eurasia. Results: We revealed an ancient connection of this lineage with populations in Siberia. However, this paternal lineage experienced an in-situ expansion between 5,000 and 3,000 years ago in northwestern China. Ancient populations with high frequencies of Q-M120 were involved in the formation of ancient Huaxia populations before 2,000 years ago; this haplogroup eventually became one of the founding paternal lineages of modern Han populations. Conclusion: We provided a clear pattern about the origin and diffusion process of haplogroup Q1a1a-M120, as well as the role of this paternal lineage during the formation of ancient Huaxia populations and modern Han populations.

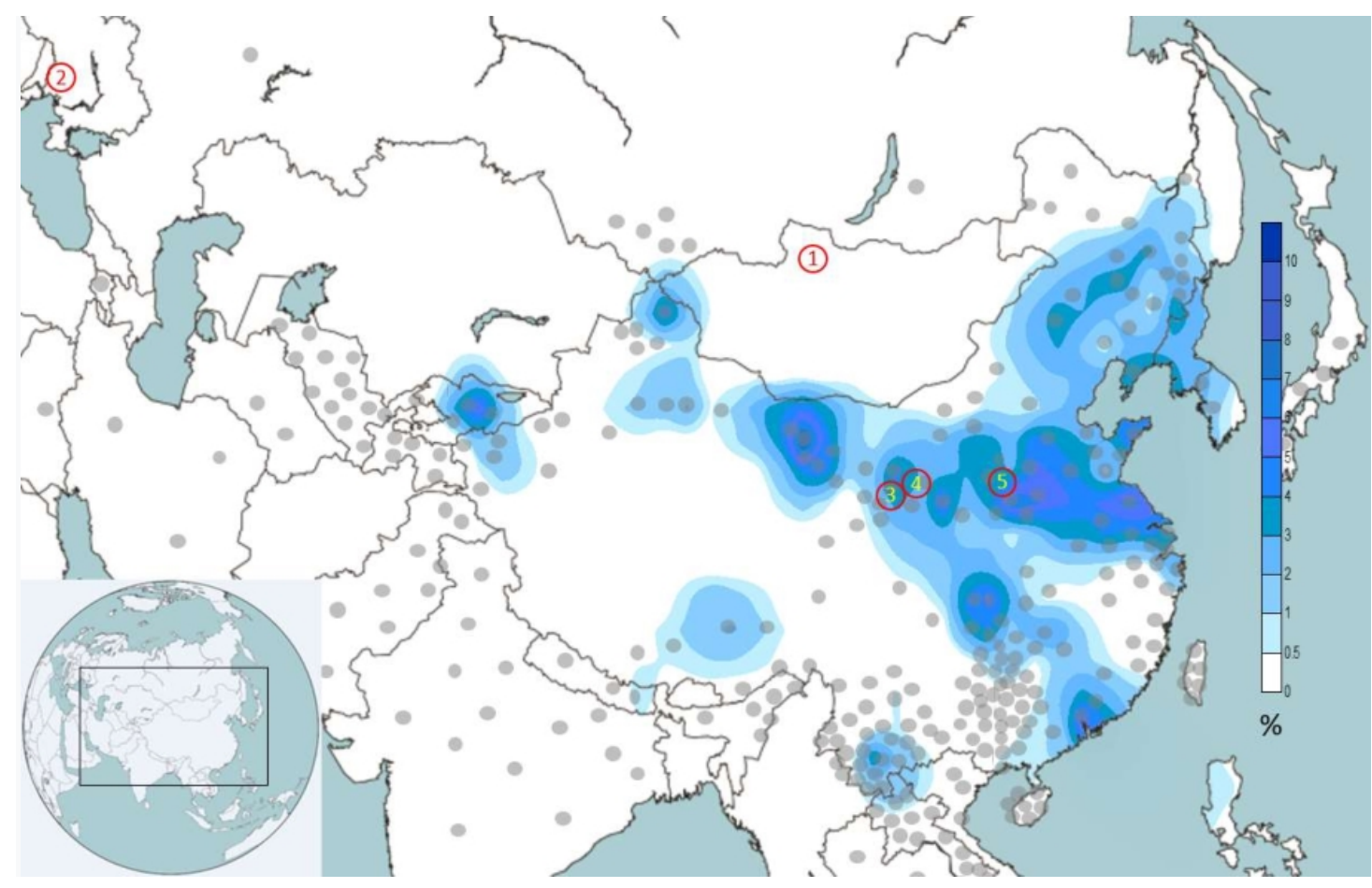

Distribution of haplogroup Q-M120. Contour map for the distribution of modern Q-M120 samples; red circles with number indicates archaeological sites with evidence for ancient Q-M120 individuals, including (1) for ARS015 individual from Khövsgöl of Mongolia, (2) for Cimmerian cim358 individual from Moldova, (3)for Zhongzhuang site, (4) 
for Wangdahu site, and (5) for Hengbei sites in the Central plain of China.

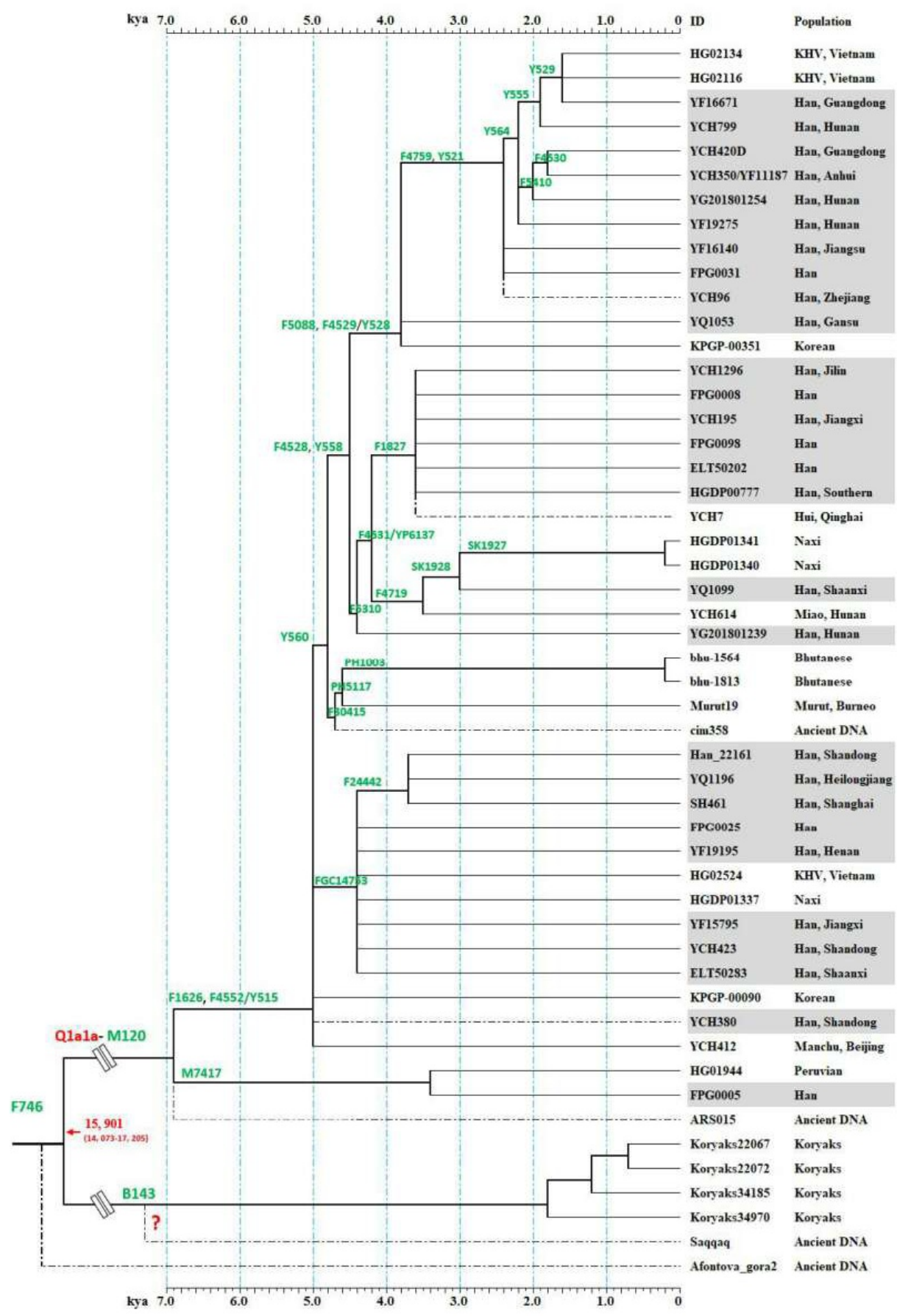

Phylogeny of Q-M120 and divergence time estimates. Samples from Han ethnic group were indicated with gray background. 


\section{Furthermore, the text below is part of the discussion Phylogeography of Y-chromosome haplogroup Q1a1a-M120, a paternal lineage connecting populations in Siberia and East Asia:}

founding paternal lineage of modern Han populations. Haplogroup Q-M120 initially

diverged 7,000 years ago and experienced a significant expansion between 5,000 years and 3,000 years before present. All available ancient DNA from Q-M120 individuals is from northwest China and several locations outside of China. Therefore, we proposed that ancient populations with the dominant paternal lineage Q-M120 lived in northwestern China between 5,000 years and 3,000 years before present. Our results are consistent with the theory of Zhao et al. (2014) that ancient populations with the dominant lineage Q-M120 were involved in the formation of ancient Huaxia populations at least 3000 years ago (around the Zhou Dynasty of China) (Zhao et al. 2014). Since then, haplogroup Q-M120 became part of paternal gene pool of Han populations. Furthermore, three sub-branches of Q-M120 (F30415, FGC14753, and

\section{Besides, the table below is Y-DNA Q samples from ancient sites in}

\section{China:}

- China

- Hengbei site (Peng kingdom cemetery of Western Zhou period), Jiang County, Shanxi, 2800-3000YBP: 9 Q1a1-M120, 2 O2a-M95, 1 N, 4 O3a2-P201, 2 O3, $4 \mathrm{O}^{*[153]}$

- In another paper, the social status of those human remains of ancient Peng kingdom(倗国) are analyzed. aristocrats: 3 Q1a1 (prostrate 2, supine 1), 2 O3a (supine 2), $1 \mathrm{~N}$ (prostrate) / commoners : 8 Q1a1 (prostrate 4, supine 4), 3 O3a (prostrate 1, supine 2), 3 O* (supine 3)/ slaves: 3 O3a, 2 O2a, 1 $\mathrm{O} *[154]$

- (cf) Pengbo (倗伯), Monarch of Peng Kingdom is estimated as Q-M120.

- Pengyang County, Ningxia, 2500YBP: all 4 Q1a1-M120[153] (with a lot of animal bones and bronze swords and other weapons, etc.)

- Heigouliang, Xinjiang, 2200YBP: 6 Q1a* (not Q1a1-M120, not Q1a1b-M25, not Q1a2-M3), 4 Q1b-M378, 2 Q* (not Q1a, not Q1b: unable to determine subclades):[155]

- In a paper (Lihongjie 2012), the author analyzed the Y-DNAs of the ancient male samples from the 2nd or 1st century BCE cemetery at Heigouliang in Xinjiang - which is also believed to be the site of a summer palace for Xiongnu kings - which is east of the Barkol basin and near the city of Hami. The Y-DNA of 12 men excavated from the site belonged to Q-MEH2 (Q1a) or Q-M378 (Q1b). The Q-M378 men among them were regarded as hosts of the tombs; half of the Q-MEH2 men appeared to be hosts and the other half as sacrificial victims.

- Xiongnu site in Barkol, Xinjiang, all 3 Q-M3

- In L. L. Kang et al. (2013), three samples from a Xiongnu) site in Barkol, Xinjiang were found to be Q-M3 (Q1a2a1a1). And, as Q-M3 is mostly found in Yeniseians and Native Americans, the authors suggest that the Xiongnu had connections to speakers of the Yeniseian languages. ${ }^{[156][157] ~ T h e s e ~}$ discoveries from the above papers (Li 2012, Kang et al., 2013) have some positive implications on the not as yet clearly verified theory that the Xiongnu were precursors of the Huns. 
Furthermore, the image below is a hypothesis of the migrating routes of Zhou People(周人) :

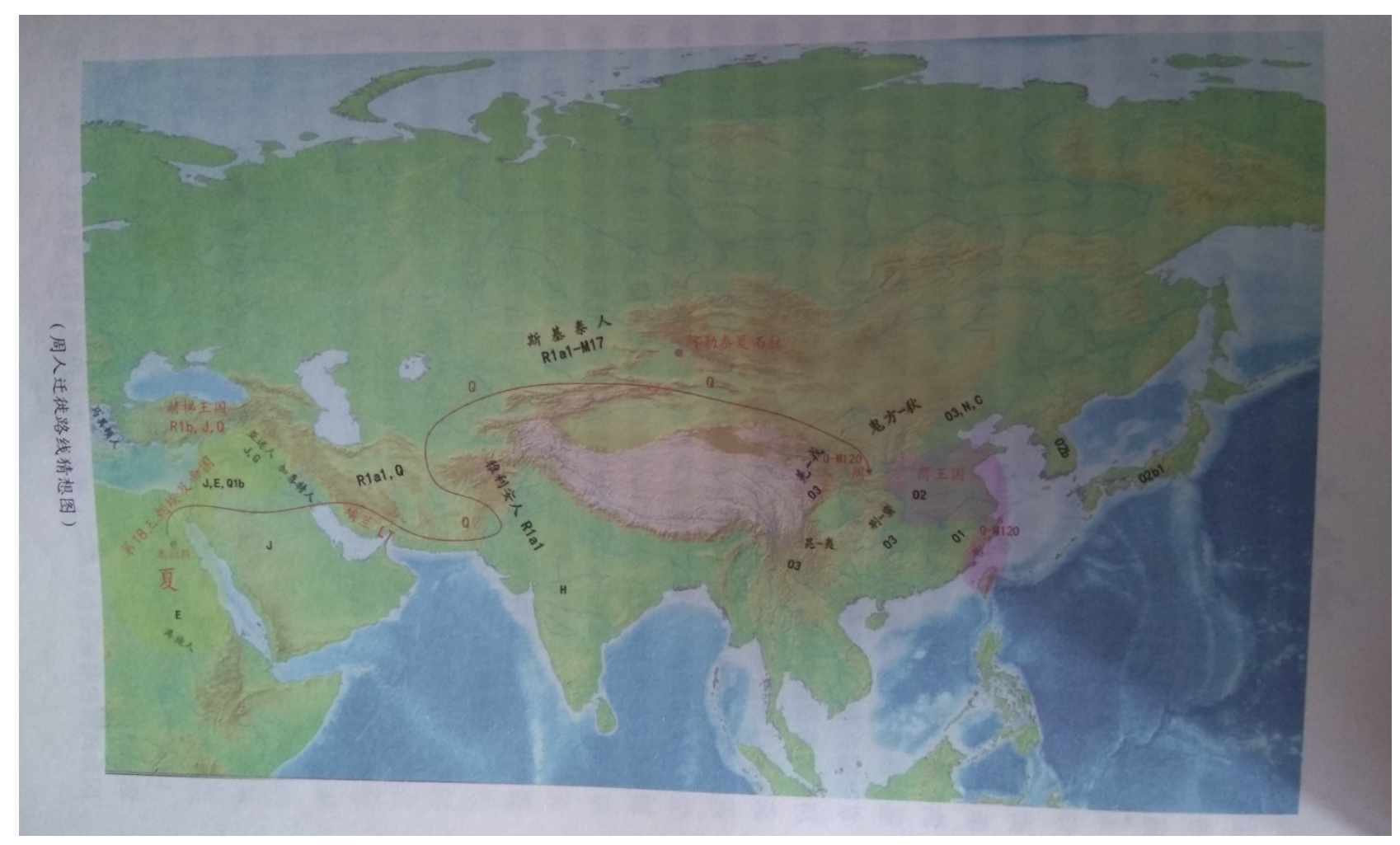

A hypothesis of the migrating routes of Zhou People(周人)

In a study (Zahery 2011), the frequency of $Q$ is $1.9 \%$ (3/154: all QM378) in Iraqis (x Marsh Arabs), and 2.8\% (4/143: 1 Q-M25, 3 Q-M378) in Marsh Arabs who are known as the descendants of ancient Sumerians(Al-Zahery, Nadia; et al. (2011) and http://www.faculty.ucr.edu/ legneref/biados/texts/WintersPokotia.htm). Besides, The dynastic race theory holds that the earliest roots of the ancient Egyptian dynastic civilization were imported by invaders from Mesopotamia who then founded the First Dynasty and brought culture to the indigenous population. Furthermore, according to the 
theory, the Haplogroup of the elite of the ancient Egypt(especially pharaohs) may be $Q$.

Approximately $2.5 \%\left(4 / 157: 3 Q^{*}, 1\right.$ Q-M346) of males in Saudi Arabia belong to haplogroup $Q$. It also accounts for $1.8 \%\left(3 / 164: 2 Q^{*}, 1\right.$ Q-M346) in the United Arab Emirates and $0.8 \%$ (1/121: $Q^{*}$ ) in Oman peoples(Cadenas AM, Zhivotovsky LA, Cavalli-Sforza LL, Underhill PA, Herrera RJ (March 2008) and Abu-Amero, Khaled K.; Hellani, Ali; Gonzalez, Ana M.; Larruga, Jose M; Cabrera, Vicente M; Underhill, Peter A (2009)). In my point of view, the males of haplogroup $Q$ in Saudi Arabia and the United Arab Emirates and in Oman peoples may came from ancient Egypt.

Haplogroup Q-M242 has also been found in $1.1 \%$ (1/87, QP36) Syrians(Karafet, TM; et al. (Feb 2005)) and 2.0\% (18/914, 14 Q*, 4 QM25) in Lebanese(Zalloua PA, Xue Y, Khalife J, et al. (April 2008)). By the way, they are part of the Eighteenth Dynasty of Egypt.

While Q1a is more Mongolian, Siberian and Native American, Q1b1 (F1213) appears to have originated in Central Asia and migrated early to South Asia and the Middle East. The highest frequency of Q1b1 in Europe is found among Ashkenazi Jews (5\%) and Sephardic Jews (2\%), suggesting that Q1b was present in the Levant before the Jewish disapora 2,000 years ago. In fact, Jewish Q1b all belong to the Y2200 subclade, which was formed some 2,600 years ago. Other subclades of Q1b1 are found throughout the Middle East, including, Armenia, Turkey, Iraq, Lebanon (2\%), and in isolated places settled by the Phoenicians in southern Europe (Crete, Sicily, south-west Iberia). This means that Q1b must have been present in the Levant at latest around $1200 \mathrm{BCE}$, a very long time before the Hunnic migrations. 
Haplogroup Q is rarely found across North Africa. It is observed in $0.7 \%$ (1/147)( Abu-Amero, Khaled K.; Hellani, Ali; Gonzalez, Ana M.; Larruga, Jose M; Cabrera, Vicente M; Underhill, Peter A (2009)), of Egyptians and in $0.6 \%$ (1/156)( Bekada, Asmahan; et al. (2013)) of Algerian people.

So at the end of the paper, we can get a hypothesis that Zhou People(周人) may be the Tribe of Dan , one of the tribes of Israel.

\section{References:}

1. http://www.yyulw.com/english/12148561.html

2. https://en.wikipedia.org/wiki/The_Exodus

3. https://en.wikipedia.org/wiki/Chinese_New_Year

4. https://hebrew4christians.com/Holidays/Spring_Holidays/Pesach/Int roduction/introduction.html

5. http://www.vividict.com/Public/index/page/index/index.html

6. https://en.wikipedia.org/wiki/Divine_right_of_kings

7. https://en.wikipedia.org/wiki/Mandate_of_Heaven

8. https://en.wikipedia.org/wiki/God_in_Judaism

9. https://en.wikipedia.org/wiki/Shangdi

10. https://en.wikipedia.org/wiki/Temple_of_Heaven

11. http://tushuo.jk51.com/tushuo/10564851.html

12. https://en.wikipedia.org/wiki/Tian

13. https://en.wikipedia.org/wiki/Hou_Ji

14. Guangbao Liu “Xia Dynasty of Eagle and Snake” (刘光保, 《发现夏 朝》, 中国发展出版社, 2017 年 12 月)

15. http://blog.sina.com.cn/s/blog_6a4e1c6f0102vu1n.html

16. https://en.wikipedia.org/wiki/Hemaka 
17. http://blog.sina.com.cn/s/blog_6a4e1c6f0102xyti.html

18. http://blog.sina.com.cn/s/blog_6a4e1c6f0102vupx.html

19. https://en.wikipedia.org/wiki/Tribe_of_Dan

20. https://en.wikipedia.org/wiki/Wadjet

21. https://en.wikipedia.org/wiki/Merneptah_Stele

22. https://en.wikipedia.org/wiki/Doctrine_of_the_Mean

23. https://en.wikipedia.org/wiki/Haplogroup_Q-M242

24. http://blog.sina.com.cn/s/blog_6a4e1c6f0101cxhn.html

25. https://www.eupedia.com/europe/Haplogroup_Q_Y-DNA.shtml

26. https://en.wikipedia.org/wiki/Haplogroup_Q-M120

27.https://www.researchgate.net/publication/333847488_Phylogeogra phy_of_Y-chromosome_haplogroup_Q1a1a-

M120_a_paternal_lineage_connecting_populations_in_Siberia_and_ East_Asia

28. https://en.wikipedia.org/wiki/Dynastic_race_theory 

